\title{
A PADRONIZAÇÃO NA GESTÃO DA CADEIA DE SUPRIMENTOS DA CARNE BOVINA POR SUPERMERCADOS
}

\author{
BRUNO LEONARDO RAVAIANI BRUM
}

Economista

Orientador: Prof. Dr. MARCOS SAWAYA JANK.

\author{
Dissertação apresentada à Escola Superior de \\ Agricultura "Luiz de Queiroz", Universidade de \\ São Paulo, para obtenção do título de Mestre em \\ Ciências. Área de concentração: Economia \\ Aplicada. \\ P IR A C I C A B A \\ Estado de São Paulo - Brasil \\ Maio - 2000
}




\title{
Dados Internacionais de Catalogação na Publicaçāo (CIP) DIVISĀO DE BIBLIOTECA E DOCUMENTAÇĀO - Campus "Luiz de Queiroz"/USP
}

\author{
Brum, Bruno Leonardo Ravaiani \\ A padronização na gestão da cadeia de suprimentos da came bovina por \\ supemercados / Bruno Leonardo Ravaiani. - - Piracicaba, 2000.

$$
123 \mathrm{p} .
$$

Dissertaçāo (mestrado) - - Escola Superior de Agricultura Luiz de Queiroz, 2000. Bibliografia.

1. Came bovina 2. Comercializaçāo 3. Indústria alimentícia 4. Mercado atacadista 5. Mercado varejista 6. Norma 7. Supermercado 8. Suprimento I. Título

CDD 338.4766492

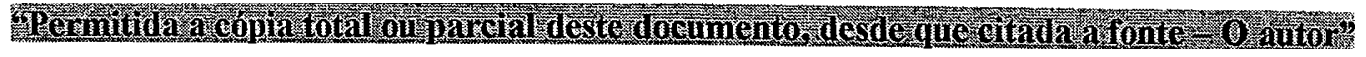


Dedico este trabalho à minha família (pai, mãe, Dani, Lucas e Ana) que, ao longo de minha vida, vem me dando $o$ apoio fundamental para 0 meu desenvolvimento pessoal e profissional. 


\section{AGRADECIMENTOS}

Agradeço em primeiro lugar ao Prof. Marcos que, diante de tantas atribuições do dia a dia, soube orientar a execução deste trabalho com bastante presteza e lucidez. A ele agradeço inclusive a escolha do tema.

Sinto-me eternamente endividado com os grandes colegas do mestrado na ESALQ pela convivência extremamente agradável durante minha estada em Piracicaba. Especialmente aos colegas de república, em ordem "cronológica": Felipe "Bigato", Augusto "Gaúcho", Fábio "Bixo", Arimatéia "Ari”, Emerson, Fabiano "Ona", José "Zé”, Marcelo “Leopoldina", e ao amigo Glauco "Santo Antônio".

Aos professores do Departamento de Economia, Administração e Sociologia, pela formação acadêmica de notável qualidade. Aos funcionários, Maielli, Helena, Lú, Cris, Pedro, Márcia, Valdeci, Elenice e Ligiana.

Àqueles que eu não citei e que sabem que contribuíram para a realização deste trabalho.

À CAPES, provedora de recursos deste projeto. 


\section{SUMÁRIO}

Página

SUMÁRIO

vi

Lista de figuras

viii

Lista de tabelas

ix

RESUMO

xi

SUMMARY

xiii

1 INTRODUÇÃO

15

$\begin{array}{ll}1.1 \text { Objetivos } & 18\end{array}$

1.2 Hipóteses $\quad 20$

$\begin{array}{ll}1.3 \text { Estrutura do trabalho } & 22\end{array}$

2 GESTÃO DE CADEIAS DE SUPRIMENTO, ECR, PADRONIZAÇÃO E COORDENAÇÃO: UMA DELIMITAÇÃO CONCEITUAL 23

2.1 Gestão de cadeias de suprimento 23

$\begin{array}{ll}2.2 \text { ECR } & 28\end{array}$

2.3 A padronização e a coordenação de cadeias de suprimento 32

2.4 A cadeia de suprimento da carne bovina 39

3 METODOLOGIA $\quad 45$

3.1 Amostra $\quad 45$

3.2 Questionário $\quad 49$

3.3 Tratamento dos dados $\quad 52$

3.3.1 A análise de tabelas de contingência

3.3.2 Classificação em categorias $\quad 54$ 
3.3.3 Tabelas de contingência

3.3.4 Nomenclatura $\quad 56$

3.3.4.1 Classificações independentes $\quad 56$

3.3.5 Teste Qui-quadrado $\quad 58$

3.3.6 O teste exato de Fisher e a correção de Yates 59

4 RESULTADOS 62

4.1 A caracterização da empresa e o conhecimento de novas tecnologias 62

4.2 A padronização na comercialização de carne bovina in natura. 68

4.3 Características do hábito de compra de carne bovina 71

4.4 A coordenação de fornecedores na comercialização de carne bovina in $\begin{array}{ll}\text { natura. } & 77\end{array}$

5 ANÁLISE DOS DADOS $\quad 80$

5.1 Teste da hipótese um $\quad 80$

5.2 Teste da hipótese dois. $\quad 84$

$\begin{array}{ll}5.3 \text { Teste da hipótese três. } & 89\end{array}$

6 CONCLUSÕES

$\begin{array}{ll}\text { ANEXO A } & 101\end{array}$

A.1 Histórico das estratégias de crescimento do setor supermercadista brasileiro 101

A.2 Situação financeira das firmas líderes $\quad 105$

$\begin{array}{ll}\text { ANEXO B } & 108\end{array}$

ANEXO C $\quad 112$

$\begin{array}{ll}\text { ANEXO D } & 115\end{array}$

ANEXOE $\quad 118$

$\begin{array}{ll}\text { ANEXOF } & 119\end{array}$

$\begin{array}{ll}\text { BIBLIOGRAFIA } & 121\end{array}$ 


\section{LISTA DE FIGURAS}

Página

1. Um esquema das fronteiras tecnológicas consideradas neste trabalho.

2. Níveis de utilização das proxys escolhidas para representar as práticas de padronização no recebimento de carne bovina in natura pela loja de supermercado.

3. Níveis de utilização das proxys escolhidas para representar as práticas de padronização na venda de carne bovina in natura pela loja de supermercado.

4. Responsável direto pela reposição de carne bovina in natura (Questão 15).

5. Tipos usuais de contatos para a reposição de carne bovina in natura.

6. Frequência de compra de carne bovina in natura.

7. Fatores decisivos para a decisão do volume de carne comprada.

8. Fatores decisivos para a decisão de escolha do fornecedor.

9. Número de fornecedores de carne bovina in natura.

10. Ações redutoras de custos na reposição de estoques. 76

11. Volume médio aproximado de carne bovina comprada por semana pela loja por estrato de tamanho.

12. Niveis de utilização das proxys escolhidas para representar as práticas de coordenação de fornecedores de carne bovina in natura pela loja de supermercado.

13. As redes de valor agregado (VAN's) 


\section{LISTA DE TABELAS}

Página

1. Empresas consideradas no estudo da Pricewaterhouse Coopers. 29

2. Resultados projetados de economias esperadas com a adoção do ECR. 30

3. Comparativo entre os resultados projetados de economias com a adoção do ECR no Brasil e as economias observadas em regiões selecionadas.

4. Definição da estratificação da amostra com base na participação da cada estrato de tamanho no total de lojas (check-outs) constantes na população (ranking da ABRAS).

5. Indicadores de tamanho - Comparativo São Paulo X Ranking ABRAS 1998. 46

6. Dimensionamento da amostra em relação ao tamanho da população

7. Comparação da proporcionalidade de número de lojas participantes com o número total de lojas de cada estrato na população.

8. Informações operacionais sobre a pesquisa de campo no estado de São Paulo.

9. Informações operacionais sobre a pesquisa de campo na RMBH.

10. Questões da parte 3 do questionário referentes ao nível de utilização de prérequisitos para a padronização (conceito ECR).

11. Questões da parte 4 do questionário referentes ao nivel de utilização de prérequisitos para a coordenação.

12. Métodos estatísticos de interdependência.

13. Exemplo de proxys para grupos de variáveis investigadas utilizadas na pesquisa de campo: padronização, tamanho e coordenação.

14. Exemplo de tabela de contingência com múltiplas categorias 55

15. Exemplo de tabela de contingência para o caso deste trabalho 60

16. Recursos disponíveis na loja (Questão um do questionário) 63

17. Importância de variáveis competitivas (Questão dois do questionário) 64

18. Relação estatística entre a importância de variáveis competitivas e o tamanho das lojas (Questão dois e tamanho).

19. Nivel de conhecimento de novas tecnologias (Questão três).

20. Relação estatística entre o nivel de conhecimento de novas tecnologias e o tamanho da firma (Questão três e tamanho). 
21. Teste para avaliação da dependência entre proxys de padronização na comercialização de carne bovina in natura em supermercados e tamanho da loja e da firma.

22A. Teste para avaliação da dependência entre proxys de coordenação de fornecedores na comercialização de carne bovina in natura em supermercados e proxys de padronização.

22B. Teste para avaliação da dependência entre proxys de coordenação de fornecedores na comercialização de carne bovina in natura em supermercados e proxys de padronização.

22C. Teste para avaliação da dependência entre proxys de coordenação de fornecedores na comercialização de carne bovina in natura em supermercados e proxys de padronização.

23. Teste para avaliação da dependência entre proxys de coordenação de fornecedores na comercialização de carne bovina in natura em supermercados e o tamanho da loja.

24. Indicadores de eficiência operacional das firmas líderes - $1997 \quad 105$

25. Correlações simples entre indicadores escolhidos 106

26. Beneficios das tecnologias de identificação automática 109

27. Padrões de EDI para indústrias especificas 


\title{
A PADRONIZAÇÃo NA GESTÃo dA CADEIA dE SUPRIMENTOS DA CARNE BOVINA POR SUPERMERCADOS
}

\author{
Autor: BRUNO LEONARDO RAVAIANI BRUM \\ Orientador: PROF. MARCOS SAWAYA JANK.
}

\section{RESUMO}

Com o objetivo de identificar a relação estabelecida entre a padronização na comercialização de carne bovina in natura por supermercados, a coordenação de fornecedores e o tamanho da firma supermercadista, foi realizada uma pesquisa junto a lojas de supermercados do estado de São Paulo e da região metropolitana de Belo Horizonte, a partir de um questionário estruturado que abordou também aspectos relacionados ao conhecimento de novas tecnologias do varejo e aos hábitos de compra de carne bovina in natura. Utilizando-se da análise de tabelas de contingência, foram relacionadas as três variáveis objeto da pesquisa e verificada a existência ou não de dependência estatística entre elas. Os resultados obtidos permitem concluir que existe a esperada forte dependência estatística entre a coordenação de fornecedores e o tamanho da firma supermercadista, bem como entre a coordenação de fornecedores e a padronização de processos na comercialização de carne bovina, mas não permitem observar a relação de dependência esperada entre a padronização e o tamanho da firma. Além disso, os resultados permitiram o conhecimento das práticas mais utilizadas e das práticas de fronteira da padronização na comercialização de carne bovina in natura, bem 
como as práticas mais utilizadas e as práticas de fronteira na coordenação de fornecedores. Identificou-se que o recebimento de carne desossada e embalada em peças é uma prática mais utilizada no recebimento de carne bovina, e que o recebimento de carne desossada e embalada em cortes prontos, paletizada é uma prática de fronteira da padronização. Pelo lado da coordenação, as práticas de preferência na descarga para entrega em horário programado e de preços diferenciados para os fornecedores que entregam a carne desossada são as mais utilizadas, enquanto a contratação de fornecedores de carne ainda é uma prática de fronteira da coordenação. De maneira geral, concluiu-se que a implantação de ferramentas como a gestão de cadeias de suprimento tem a sua viabilidade comprometida no curto prazo, devido principalmente à reduzida difusão de práticas de padronização entre todos os estratos de tamanho das firmas supermercadistas e às dificuldades impostas pelo pequeno conhecimento das novas ferramentas tecnológicas para o varejo. 


\title{
THE STANDARDIZATION ON THE BEEF SUPPLY CHAIN MANAGEMENT BY SUPERMARKETS
}

\author{
Author: BRUNO LEONARDO RAVAIANI BRUM
}

ADVISER: PROF. MARCOS SAWAYA JANK

\section{SUMMARY}

With the goal on identify the relationship between the standardization on the beef buying and selling by supermarkets, the coordination of suppliers and the size of the firm, was made a survey on supermarket firms on the state of São Paulo and on the metropolitan area of Belo Horizonte, with a structured questionnaire that also researched the knowledge level of new retail technologies and the supermarket purchase behaviour of beef. Using contingency tables analysis, had been related the three focus variables and investigated the statistical dependence relationship between them. The results lead to a conclusion that exists the strong statistical dependence relationship between the coordination of suppliers and the size of the firm, and between coordination and standardization on the beef buying and selling process, but not between the standardization and the size of the firm. Moreover, there was demonstrated the knowledge of the most common practices and the best practices of standardization on the beef buying and selling process, and of the most common practices and the best practices of coordination of suppliers. There was identified that the receiving of piece packed unbone beef (boxed beef) is the most common practice, and the palleted boxed 
beef is the best practice on the receiving of beef. On coordination, the preference on outlet to programmed time deliver and the price differentiation to suppliers that deliver the boxed beef are the most common practices, while the beef supplier contracting is a best practice. Finally, the results lead to the conclusion that the implementation of managerial tools like the supply chain management is rendered difficult on the short run, essencially because the low diffusion of the standardization practices between all supermarket size categories and the dificulties imposed by the low knowledge of new retail managerial tools and technologies. 


\section{INTRODUÇÃo}

Ao longo da década dos 90 vem tomando forma uma nova estratégia de crescimento das firmas que operam na cadeia de suprimento de alimentos, de maneira mais contundente nos Estados Unidos. Tal estratégia baseia-se na gestão da cadeia de suprimentos (supply chain management), ou seja, na realização de parcerias entre o setor varejista, o setor atacadista, os setores industriais e de outros serviços e o setor primário, visando a redução dos custos envolvidos com a distribuição de alimentos. Esta gestão da cadeia de suprimentos de alimentos, um conceito vinculado ao do Just In Time (JIT) idealizado pela indústria japonesa na década dos 80 , recebeu o nome de Efficient Consumer Response (ECR), ou Resposta Eficiente ao Consumidor.

Com a relativa estabilidade de preços alcançada pelo Brasil após 1994, os supermercados viram-se obrigados a redefinirem suas estratégias de atuação, privilegiando cada vez mais a necessidade de se obter resultados operacionais em detrimento dos resultados financeiros. Nesse período intensificou-se a ameaça de entrada de grupos estrangeiros no mercado brasileiro, o que pode ser comprovado pelo grande número de operações de compra de supermercados brasileiros. Observou-se também o aumento da necessidade de inovações dinâmicas ao nível dos serviços prestados pelos supermercados, devido à rápida imitação/adaptação de novas práticas que se observa no setor e à pressão sobre a rentabilidade das firmas líderes (Ver anexo A).

A conjunção desses fatores tornou premente a necessidade de redução dos custos associados à distribuição. Posto que os preços não são tão flexíveis, e que a pressão sobre os custos internos da firma respeitam um determinado limite, ganha importância a busca pela redução dos custos externos. 
É dentro do contexto de necessidade de redução dos custos associados à logística de distribuição que surge no Brasil a demanda pelas estratégias de gestão de cadeias de suprimento, no caso o ECR, principalmente por parte das firmas líderes do setor supermercadista.

$O$ ECR baseia-se num conjunto de ferramentas que, implantadas em conjunto, visam criar um canal de distribuição que compartilha informações da demanda final, de forma a diminuir o desnivelamento de estoques ao longo da cadeia e, com isso, diminuir os custos tanto no nível das firmas quanto no nível sistêmico. Uma dessas ferramentas é a padronização ${ }^{1}$. A padronização para o ECR refere-se ao estabelecimento de procedimentos comuns e estáveis de identificação de produtos através de códigos de barras, à definição de uma tipologia básica de embalagens e de veículos a serem utilizados no transporte ao longo da cadeia. Refere-se mais, portanto, ao conceito de padronização de processos. Observa-se, portanto, o caráter abrangente e de longo prazo envolvido com o ECR.

O compartilhamento de informações entre os vários níveis de uma cadeia visando a redução dos custos remete à questão da coordenação ${ }^{2}$ de cadeias de suprimento. A real possibilidade da adoção de estratégias como o ECR estaria vinculado à capacidade de coordenação entre os vários níveis de uma cadeia de suprimento. Ao tratar-se da padronização especificamente a importância da coordenação aumentaria, já que ações isoladas neste sentido teriam uma efícácia questionável.

A padronização seria, portanto, peça chave para estratégias como o ECR, já que facilitaria a coordenação de cadeias de suprimento agroindustriais. A necessidade de coordenação de cadeias de suprimento agroindustriais seria tanto maior quanto maiores

\footnotetext{
${ }^{1}$ As outras ferramentas serão apresentadas no próximo item do trabalho. Ao longo do restante do texto o termo padronização estará relacionado a esta definição.

${ }^{2}$ Encadeamento de transaçōes que se sucedem para produzir um produto final, em que partes e contrapartes são identificadas $\theta$ asseguram a continuidade da relação por meio de uma estrutura de governança particular. Diz respeito ao governo das transações verticais de uma firma especifica, associado à sua estratégia de concorrência (Zylberstajn e Farina, 1997). Neste trabalho será captada somente a coordenação entre supermercados e o elo imediatamente anterior na cadeia de suprimento.
} 
fossem as dificuldades impostas à padronização pelas características específicas de cada uma das cadeias.

Alguns fatores foram determinantes para a escolha da comercialização da carne bovina in natura como objeto de análise deste trabalho. O primeiro é o fato de que a cadeia de suprimento desse produto é reconhecida como um das que mais são afetadas por informação assimétrica entre os agentes e por fraca ou ausente padronização de procedimentos, desde a produção animal até a comercialização nos supermercados e açougues.

Em segundo lugar, no que se refere especificamente ao supermercado, a importância da manutenção do mix de produtos e as altas margens auferidas no açougue fazem com que esta seja uma seção imprescindível dentro das lojas. Com a pressão advinda principalmente da maior demanda por produtos frescos de qualidade, e do crescimento da participação destes como um dos fatores que induzem à compra em supermercados, aumenta a necessidade de se ofertar a carne bovina in natura com garantia de procedência, validade e preços competitivos.

Por último, espera-se um aumento contínuo da demanda por carne bovina in natura, devido ao aumento natural da população e pelas características da alimentação do brasileiro. Assim, o supermercado sente-se pressionado a promover uma readaptação do açougue, atendendo às necessidades da demanda final e, ao mesmo tempo, considerando a sua estrutura de custos (tamanho), que seria um fator restritivo aos investimentos requeridos.

Tal readaptação referir-se-ia principalmente à necessidade de adoção de procedimentos padronizados de comercialização da carne bovina in natura dentro das lojas, o que envolveria também procedimentos padronizados de produção, corte, embalagem e transporte.

Contudo, os supermercados nem sempre conseguem utilizar-se da padronização em todas essas fases. Pode haver os que não conseguem utilizar-se em nenhuma, alguns podem conseguir utilizar até a embalagem, outros já podem conseguir utilizar a 
padronização até na produção.

Portanto, a busca pela padronização na comercialização da carne bovina in natura dentro do contexto de gestão de cadeias de suprimento pode estar relacionada a dois grupos de variáveis: às relacionadas com a coordenação de fornecedores e às relacionadas à heterogeneidade das estruturas de custo e do tamanho dos supermercados. Os efeitos de ambos os grupos de variáveis (coordenação e tamanho) sobre a padronização não são cientificamente conhecidos, sofrendo apenas especulações de especialistas e agentes envolvidos com o setor supermercadista.

\subsection{Objetivos}

O objetivo principal deste trabalho é o de fornecer subsídios para a compreensão da relação entre a padronização de processos na comercialização de carne bovina in natura, a coordenação de fornecedores nos supermercados e o tamanho da firma supermercadista com o intuito de:

1) fornecer aos supermercados um posicionamento no que se refere à fronteira tecnológica (melhores práticas) de padronização na comercialização de carne bovina in natura;

2) propiciar às entidades envolvidas com a implantação do ECR no Brasil uma espécie de ranking dos supermercados e o distanciamento destas em relação à uma hipotética fronteira tecnológica de padronização.

A inspiração para o conceito de fronteira tecnológica é o da teoria microeconômica neoclássica. Neste caso, estando sobre a fronteira a firma é capaz de obter o máximo de produto com combinações diferenciadas de insumos. Diz-se inspiração pois o conceito não é plenamente aplicável a este trabalho.

Em primeiro lugar, o que se define aqui como uma fronteira tecnológica é o conjunto de melhores práticas de padronização e coordenação, aqui representadas por 
algumas variáveis escolhidas. Para que um supermercado esteja próximo de tal fronteira, ele deve utilizar-se de um percentual razoável da variável escolhida como representativa da fronteira tecnológica. Se tal fato ocorrer, diz-se que o supermercado está próximo de uma fronteira tecnológica limite, ou seja, utiliza-se muito da melhor prática possível.

Se o supermercado utilizar-se de um reduzido percentual da variável escolhida como representativa da fronteira tecnológica, então diz-se que está distante da fronteira tecnológica limite. Neste caso, deve ser conhecida qual é a fronteira tecnológica possível, ou seja, qual é, dentre as outras variáveis escolhidas como representativas de uma fronteira tecnológica, aquela que tem um percentual de utilização mais elevado. A figura 1 representa as fronteiras consideradas.

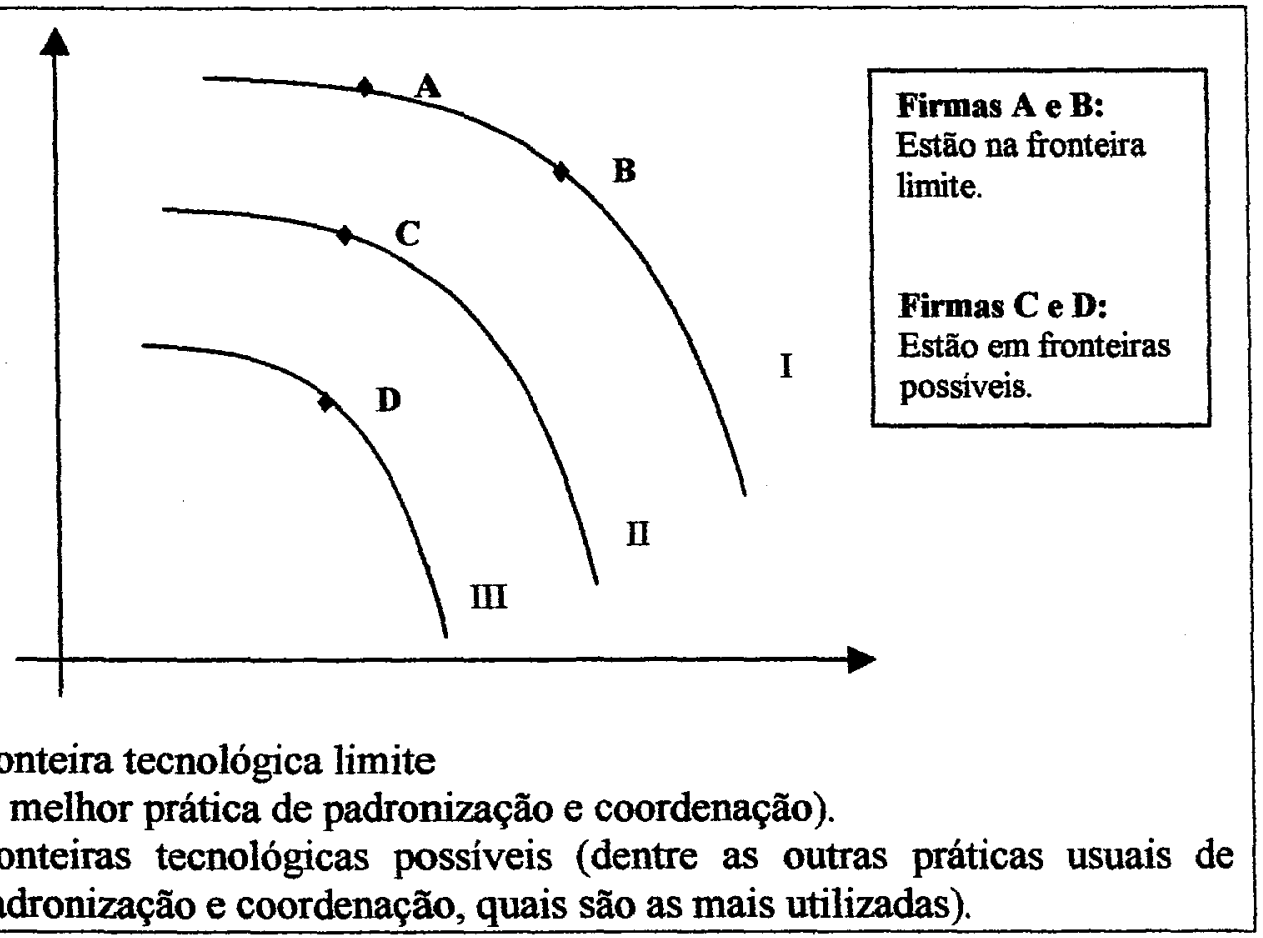

Figura 1. Um esquema das fronteiras tecnológicas consideradas neste trabalho.

Se a fronteira tecnológica fosse plenamente conhecida, para os casos da padronização na comercialização de carne bovina in natura em supermercados e da 
coordenação de fornecedores de carne bovina in natura, ou seja, caso fossem conhecidas com exatidão quais as melhores práticas de padronização e coordenação, então esta diferenciação entre fronteiras tecnológicas não teria razão de ser, e bastaria pesquisar o nivel de utilização de tais melhores práticas.

Como afirma-se anteriormente, é pequeno o conhecimento a respeito das variáveis pesquisadas, assim como sobre a relação entre elas e, devido a este fato, utiliza-se do artifício aqui apresentado.

\subsection{Hipóteses}

Como foi citada anteriormente, a relação que se estabelece entre os três grupos de variáveis estudados (padronização, coordenação e tamanho da loja) não foi ainda definida por pesquisas científicas. A maneira como se estabelece esta relação ainda fundamenta-se basicamente em especulações e opiniões de especialistas do setor supermercadista.

A revista Supermercado Moderno, por exemplo, cita que "quando se observa esta importante seção dos supermercados [açougue], nota-se que seu destino infalível é eliminar o trabalho braçal pesado, valorizar o tempo, padronizar processos e produtos, gastando menos com mão-de-obra, energia elétrica, manutenção... em suma, o açougue deverá ser muito mais produtivo e isto através da mecanização... entretanto, para que os ganhos sejam máximos, a firma terá de trabalhar com fornecedores que adotem procedimentos e produtos compatíveis com os exigidos pela nova era das máquinas". (Supermercado Moderno, 1992, p.).

Assim, a maior ou a menor padronização de processos na comercialização de carne bovina in natura dentro dos supermercados estaria relacionada à maior ou a menor capacidade de investimento da firma em máquinas e em novos processos de tratamento da carne dentro da loja.

Mesmo na teoria microeconômica tradicional encontra-se uma explicação que 
permite esperarmos uma determinada relação entre a padronização e o tamanho das lojas. Se, como afirmam a reportagem e os especialistas, a padronização é uma ferramenta redutora de custos, ou seja, que permite o deslocamento para baixo da curva de custo médio das lojas, então ela toma a firma mais lucrativa em relação às concorrentes que não a utilizarem, tudo o mais constante. Obviamente, as firmas que primeiro se movimentam neste sentido são as "líderes", ou aquelas que têm uma maior capacidade de perceber as oportunidades de melhoria na eficiência e efetivamente operacionalizam tais oportunidades.

Diante disto, espera-se neste trabalho que a distância de uma loja da fronteira tecnológica limite da padronização na comercialização de carne bovina in natura seja inversamente relacionada ao tamanho desta loja. Assim, espera-se que as maiores lojas estejam mais próximas de uma fronteira tecnológica limite de padronização. Esta é a hipótese um.

Além da hipótese um, a citação acima permite a defínição da hipótese dois. Ao citar que a firma que queira maximizar os ganhos com a padronização teria que trabalhar com fornecedores que adotem procedimentos e produtos compativeis, faz-se uma clara referência à questão da coordenação.

Espera-se que a distância de uma loja da fronteira tecnológica da padronização na comercialização de carne bovina in natura é inversamente relacionada à capacidade de coordenação de fornecedores por parte da loja. Assim, espera-se que as lojas que coordenam mais os fornecedores adotem mais procedimentos padronizados na comercialização de carne bovina in natura. Esta é a hipótese dois.

Tomando emprestados alguns conceitos da Nova Economia das Instituições identifica-se que para um mecanismo de coordenação se tornar eficaz deve ser composto por instrumentos de incentivo e de controle. Portanto, se um supermercado deseja implantar a padronização e, caso queira maximizar os ganhos com esta ferramenta, deve trabalhar com fornecedores que adotem procedimentos e produtos compatíveis, então é razoável supor que ele deverá criar mecanismos de incentivo e de controle para que seus fornecedores se enquadrem no esquema da padronização. 
É reconhecido pela literatura que trata do conceito de gestão de cadeias de suprimento que a maior ou a menor probabilidade de sucesso de uma integração de fornecedores está mais ou menos relacionada à relação de poder e confiança existente entre $o$ agente integrador $\mathrm{e} o$ agente integrado.

No caso, quanto maior é o poder de mercado do agente integrador, maior é a capacidade de determinar as ações de seu interesse para o agente a ser integrado. Assim, quanto maior a firma supermercadista, espera-se que um maior número de mecanismos de coordenação sejam utilizados. Ou seja, espera-se que as maiores lojas estejam mais próximas de uma fronteira tecnológica hipotética de coordenação. Esta é a hipótese três.

O capitulo dois deste trabalho joga luz sobre os conceitos pesquisados, e, dessa forma, procura esclarecer mais a fundo as relações estabelecidas aqui nesta introdução, relações estas de caráter consideravelmente $a d$ hoc.

\subsection{Estrutura do trabalho}

Neste capitulo 1 fez-se uma apresentação do problema a ser estudado, qual seja, a montagem de sistemas de padronização na comercialização de carne bovina in natura por supermercados, dentro do contexto do ECR. Foram apresentados os objetivos principais e secundários desse trabalho e foram demonstradas as hipóteses básicas que norteiam este estudo e a estrutura do trabalho. No capítulo 2 realiza-se uma primeira revisão bibliográfica discutindo os principais conceitos relacionados a este trabalho, como a gestão de cadeias de suprimento, o ECR, a padronização e a coordenação, no sentido de fortalecer e embasar as hipóteses consideradas. No capítulo 3 apresenta-se a metodologia de pesquisa e o instrumental estatístico que serve de base para a análise dos resultados. No capítulo 4 faz-se uma apresentação dos resultados obtidos. No capítulo 5 apresenta-se uma discussão e análise destes. A seguir, conclui-se o trabalho com a condensação dos principais resultados e informações geradas no capítulo 6 . 


\section{GeSTÃo de CAdeIAS de SUPRIMENTO, ECR, PADRONIZAÇÃo E COORDENAÇÃO: UMA DELIMITAÇÃO CONCEITUAL ${ }^{3}$}

Pretende-se neste capítulo esquematizar o arcabouço conceitual desse trabalho. Portanto, optou-se por dividir em duas partes a revisão bibliográfica. Nesta primeira parte, trata-se apenas da revisão e apresentação de conceitos relacionados ao problema da pesquisa. No próximo capítulo apresenta-se a metodologia e faz-se a revisão bibliográfica do ferramental estatístico que servirá de base para a análise dos dados.

\subsection{Gestão de cadeias de suprimento}

O conceito de gestão de cadeias de suprimento insere-se na evolução dos conceitos logísticos, que se distribuem por cinco fases. A primeira fase é a da administração de materiais. A administração de materiais é a parte da logística empresarial que corresponde ao conjunto de operações associadas ao fluxo de materiais e informações, desde a fonte da matéria-prima até a entrada na fábrica. Os conceitos relacionados à esta fase relacionam-se somente à armazenagem e ao transporte.

A segunda fase é a da distribuição física, que consiste no conjunto das operações associadas à transferência dos bens objeto de uma transação desde o local de sua produção até o local designado no destino e ao fluxo de informações associado, devendo garantir que os bens cheguem ao destino em boas condições comerciais. Nesta fase trabalham-se conceitos relacionados à administração de materiais e incorpora-se a

\footnotetext{
${ }^{3}$ Sugere-se na leitura deste capítulo a consulta ao glossário resumido, disponível no anexo B.
} 
distribuição, como a gestão de estoques, compras, a movimentação e armazenagem, e a otimização do transporte.

Na terceira fase tem-se a logística integrada. A logística integrada é a função sistêmica de otimização do fluxo de materiais, produtos, pessoas e informações de uma organização. O sistema logístico integra duas ou mais atividades gerenciais ou operacionais, planejando, implementando e controlando o fluxo eficiente de materiais e informações, do ponto de origem ao ponto de destino, com o propósito de adequá-lo às necessidades dos fornecedores e clientes. Aqui são incorporados objetos como a gestão de pedidos, a gestão de demanda e a integração de sistemas de informação.

O supply chain management ou a gestão de cadeias de suprimento constitui-se na quarta fase dos conceitos logísticos, que compreende um enfoque sistêmico. Busca uma maior integração entre os participantes da cadeia de suprimento mediante um relacionamento mais estreito e a formação de parcerias, otimizando, portanto o fluxo de materiais e informações na cadeia. A logística como processo de integração serve de base para a definição de estratégias de empresas e não apenas como suporte à solução de problemas operacionais.

Numa quinta fase, ainda em definição, encontra-se o ECR, que é traduzido como Resposta Eficiente ao Consumidor. A aplicação da logística aqui visa a redução dos custos interetapas da cadeia. Conceitos como alianças estratégicas e a otimização logística de cadeias de suprimento são incorporadas nesta fase. Não é possível afirmar que o ECR e as estratégias correlatas sejam substitutas do supply chain management, já que o embasamento teórico destes conceitos logísticos ainda é reduzido. Apesar de serem citados os mais diversos benefícios do ECR, há uma considerável carência de avaliações empíricas, principalmente no Brasil, já que se trata de um conceito logístico novo e que ainda não tem difusão assegurada ${ }^{4}$. Há evidências, contudo, de que o ECR é

\footnotetext{
${ }^{4}$ As opiniōes de especialistas sobre o ECR no Brasil são veementes quanto aos problemas: " $O$ problema é que os latino-americanos näo gostam de parceria...o processo [ECR] cultural é $80 \%$ e o tecnológico é $20 \%$." Sobre a questão das tecnologias poupadoras de mão-de-obra: "Em primeiro lugar você náo terá esse fenômeno de DSD [Entrega Direta nas Lojas, uma das principais ferramentas do ECR.]" (Revista de Automação Comercial, 1997, p. 19).
} 
uma tendência mundial e brasileira, fato que motivou este trabalho ${ }^{5}$.

Acompanhando a evolução dos conceitos logísticos, a pesquisa científica realizada em torno das relações interfirmas tem voltado-se para uma nova forma de organização industrial que cada vez mais ganha importância no cenário internacional: as cadeias de suprimento ou supply chains. Tal pesquisa científica desenvolve-se tanto no campo gerencial (administração de empresas) quanto no campo operacional (pesquisa operacional e engenharia da produção).

Segundo Hart \& Saunders (1998), “enquanto os pesquisadores têm se interessado nas relações entre firmas por vários anos, eles recentemente têm enfatizado as relações entre comprador-fornecedor... [já que] muitos compradores têm demonstrado um desejo de estender contratos e desenvolver maiores níveis de confiança com os fornecedores".(Hart \& Saunders, 1998, p.88) ${ }^{6} \mathrm{O}$ trabalho destes autores sugere ainda que devido à crescente demanda pela gestão de cadeias de suprimento, ganham importância as novas tecnologias de informação, como o intercâmbio eletrônico de dados, ou Electronic Data Interchange (EDI), e as intranets, já que através delas é que seria possível a manutenção do fluxo de informações.

No entanto, trabalhos como o de van der Vorst et al. (1998) sugerem a incerteza envolvida com a gestão de cadeias de suprimento. Para estes autores, a mudança de uma prática de negócios que privilegia a formação de estoques como forma de regularizar o fluxo fisico para uma que favorece muito mais a agilidade, através de ferramentas como o Just in Time e o Quick Response, gera impactos sobre a forma de competição entre as firmas participantes de um dado canal de distribuição de bens, neste caso mais

\footnotetext{
${ }^{5}$ Grandes redes internacionais como Wal-Mart (E.U.A), Carrefour (França), Marks e Spencer (Reino Unido) e Royal Ahold (Holanda) têm estabelecido esforços neste sentido desde o início da década dos 90. O Grupo Pão de Açúcar lançou seu projeto de comércio eletrônico, batizado de Pd@Net. Trata-se de um sistema que utiliza a Internet como facilitador da comunicação nas transferências de arquivos e gerenciamento de EDI (troca eletrônica de dados) com seus 6 mil fornecedores. A proposta é ter $100 \%$ dos processos eletrónicos, do pedido ao controle de estoques, o que possibilitará ao fornecedor conhecer em tempo real o desempenho de seu produto, democratizatizando o acesso de pequenos e médios fornecedores ao EDI, que já intermedeia $48,7 \%$ das vendas da companhia.

${ }^{\text {B }}$ Ver Landeros \& Monczka (1989), Macbeth \& Ferguson (1994), Kalwani \& Narayandas (1995) sobre a evoluçāo conceitual de supply chains e os seus beneficios qualitativos estimados.
} 
especificamente 0 de alimentos.

Eles sugerem que deve haver uma migração de uma competição interfirmas para uma competição intercadeias, já que nesse cenário aumenta a incerteza pelo lado da oferta e pelo lado da demanda, com a redução do nível dos estoques ao longo do canal de distribuição, aumentando a necessidade de integrações verticais.

Diversos autores definem a gestão de cadeias de suprimento [Jones \& Riley (1985), Stevens (1989), Fearne (1996), entre outros]. O ponto comum sustenta-se sobre a constatação de que a gestão de cadeias de suprimento deve reconhecer os requerimentos de serviços ao nível do consumidor e definir onde posicionar estoques ao longo da cadeia e quanto armazenar em cada ponto, desenvolvendo políticas apropriadas e procedimentos para gerenciar a cadeia como uma entidade única.

Para van der Vorst et al. (1998) o sucesso das cadeias, do ponto de vista da melhoria de eficiência sistêmica, reside na diminuição de incertezas associadas e na divisão destas por todos os estágios da cadeia.

A incerteza envolvida com a gestão de cadeias de suprimento tem como sua principal fonte o chamado bullwhip effect (Lee et al., 1997): “... mesmo quando a demanda do consumidor é estável, fatores institucionais (como infra-estruturas e tempos de produção, sistemas de computadores, capacidade das máquinas, depósitos e veículos) ou aleatórios tendem a tornar a demanda mais cíclica, e com maior variância, nos níveis superiores da cadeia. (...) Este fenômeno, no qual as ordens de compra aos fornecedores tendem a ter maior variância do que as vendas aos compradores, e esta distorção se propaga para cima [na cadeia] numa forma ampliada, é chamado de bullwhip effect". (Lee et al., 1997, p. 488)".

A incerteza associada ao bullwhip effect teria impactos sobre custos, já que o fabricante incorreria em excessivos custos de matérias-primas ou falta de materiais devido à fraca previsão de produção, além de excesso de capacidade, da utilização ineficiente da capacidade produtiva e dos gastos com estoques excessivos.

A conclusão de van der Vorst et al. (1998) é que as principais barreiras para a 
melhoria do desempenho das cadeias de suprimento são as diferenças na infraestrutura de tecnologia de informação corrente e a relutância dos tomadores de decisão em relação à nova prática de negócios.

As diferenças na infra-estrutura de tecnologia de informação corrente tornam necessária a montagem de sistemas de controle em tempo real (como EDI) e o investimento sistemático em treinamento e educação. Para a manutenção de uma eficiente gestão de cadeias de suprimento é necessário que haja a possibilidade de troca de informações em tempo real e para que haja essa troca deve haver uma relação de poder e confiança ${ }^{7}$ entre cliente e fornecedor (Hart \& Saunders, 1998), nesta ordem, o que faz surgir a segunda barreira.

Podem ser reforçadas aqui as hipóteses realizadas neste trabalho. Diante de todo o aparato tecnológico necessário para a realização da troca de informações que permitiria uma eficiente e eficaz gestão da cadeia de suprimentos, observa-se a importância da capacidade de investimento das firmas participantes dessa cadeia. Portanto, no caso dos supermercados, que é o foco deste trabalho, da mesma forma as maiores firmas (ou lojas) devem estar mais preparadas para atenderem aos requerimentos tecnológicos.

A maior ou a menor relutância dos tomadores de decisão em relação à nova prática de negócios refere-se às relações de poder e confiança existentes entre supermercados e fornecedores, derivadas das características das diversas cadeias agroindustriais que vendem os seus produtos em supermercados. De acordo com as relações observadas ter-se-ia a maior ou menor possibilidade de troca de informações (via EDI) ${ }^{8}$ e o melhor ou pior desempenho da gestão de cadeias de suprimento.

Novamente, podem ser reafirmadas as hipóteses realizadas. Se existe uma forte relação de poder entre um supermercado e um fornecedor, então é esperado que a

\footnotetext{
7 Poder é a capacidade de uma firma influenciar mudanças em outra firma que é dependente dos recursos daquela firma. Confiança é a decisão de uma firma de assumir açōes de risco pressupondo que todos os agentes envolvidos agirăo de forma não oportunista.

${ }^{B}$ A apresentação completa das novas tecnologias de informação encontra-se no anexo B deste trabalho.
} 
relutância em relação à nova prática de negócios (a gestão de cadeias de suprimento, o ECR, a padronização e a coordenação) seja menor. Diante do conceito de poder, pode-se assumir que o tamanho do supermercado o permite exercer consideráveis poderes monopsonísticos sobre os fornecedores, ou sobre a cadeia de suprimento à montante.

\subsection{ECR}

Como visto anteriormente, numa quinta fase da evolução dos conceitos logísticos encontra-se o ECR. O ECR visa a reposição, o sortimento, a promoção e a introdução eficientes de produtos, utilizando-se de cerca de seis ferramentas básicas ${ }^{9}$. Para a efetiva implantação dessas seis ferramentas, cinco pré-requisitos são fundamentais, segundo o Programa ECR Brasil ${ }^{10}$ :

1) Reposição Contínua de mercadorias, que é a prática de parceria entre os membros do canal de distribuição que altera o tradicional processo de reposição de mercadorias, de geração de pedidos elaborados pelo distribuidor, baseado em quantidades economicamente convenientes, para a reposição de produtos baseada em previsão de demanda efetiva;

2) Gerenciamento de Categorias de produtos, que é o processo conjunto entre varejista e fornecedor que consiste em gerenciar as categorias de produtos como unidades estratégicas de negócios, para produzir resultados comerciais melhorados;

3) Intercâmbio Eletrônico de Dados (EDI), que é uma troca automatizada, computador a computador, de informações de negócios estruturadas, entre uma empresa e seus parceiros comerciais de acordo com um padrão reconhecido internacionalmente (conforme já visto anteriormente). São necessários o EDI Mercantil, que é o EDI entre

\footnotetext{
${ }^{9}$ A Emissão de Pedidos via Computador (CAO), o Estoque Administrado pelas Vendas (VMI), o Sistema de Recepção Eletrônica, o Cross-Docking, a Entrega Direta nas Lojas (DSD), e o Gerenciamento Baseado nas Atividades. Ver o glossário no anexo C.

${ }^{10}$ Para que todas as seis ferramentas já apresentadas funcionem harmonicamente, apoiadas nos pré-requisitos, é necessário que haja uma boa parte da infra-estrutura de novas tecnologias de informação apresentadas no anexo $B$.
} 
as empresas que compõem a cadeia de suprimento, e o EDI Financeiro, que é o EDI entre as empresas da cadeia e as instituições financeiras que dão o suporte às transações;

4) Custeio baseado em atividades, ou Custeio $\mathrm{ABC}$, que é um método de cálculo de custos baseado na alocação por atividade. Quando um produto entra na loja do supermercado ele percorre, ou "utiliza" uma série de atividades da empresa em uma determinada proporção. Assim, cabe ao método $\mathrm{ABC}$ avaliar todas as atividades percorridas, definir os indicadores de rateio e alocar os custos por produtos. Um custeio apurado é que permite o Gerenciamento por Categorias e a Reposição Contínua;

5) Padronização, que é o estabelecimento de procedimentos comuns e estáveis de identificação de produtos através de códigos de barras, à definição de uma tipologia básica de embalagens e de veículos a serem utilizados no transporte ao longo da cadeia. Sem uma distribuição padronizada, principalmente no que se refere ao produto, não é possível a identificação única e diferenciada através dos códigos de barras e, portanto, não é possível realizar um gerenciamento da cadeia de suprimento, nos moldes do ECR.

Um estudo recente da Pricewaterhouse Coopers ${ }^{11}$ identificou os potenciais benefícios para o setor supermercadista e para a cadeia à montante da adoção do ECR no Brasil, considerando as quatro principais categorias de produtos ${ }^{12}(75 \%$ das vendas) e realizando entrevistas e grupos de estudo em 21 empresas da cadeia de suprimento de alimentos. A tabela 1 apresenta as empresas consideradas.

Tabela 1. Empresas consideradas no estudo da Pricewaterhouse Coopers.

- Indústrias: Nestlé, Quaker, Sadia, Fleischmann Royal, Coca-Cola, Brahma, Gessy Lever, Reckitt \& Colmann, Ceras Johnson, Colgate Palmolive, Johnson \& Johnson e Procter \& Gamble.

- Supermercados: Pão de Açúcar, Barateiro, Demeterco, Bompreço, Lojas Populares, Cândia/Sonae e Sendas.

- Atacadistas: Martins e Ciro

Fonte: www.abrasnet.com.br/ecr-brasil

11 Estudo apresentado no I ECR Brasil, congresso realizado em São Paulo no mês de novembro de 1998 pelo consultor Daniel M. Henrich.

${ }^{12}$ Alimentos secos, Bebidas, Produtos de Auto-Serviço, Limpeza/Higiene pessoal. 
Utilizando como variáveis-chave a redução dos níveis de estoque, a redução das perdas de vendas por falta de estoques, a otimização na distribuição, a redução no tempo de recebimento fiscal, o aumento das vendas, da margem bruta e o retorno das promoções sobre os investimentos, o estudo concluiu que se pode obter com a adoção do ECR uma economia de cerca de US\$ 4,5 bilhões por ano, sendo esse ganho distribuído entre a indústria e o varejo (mais para o primeiro do que para o segundo). Na tabela 2 temos a distribuição dos ganhos de acordo com os objetivos do ECR (sortimento, introdução e reposição eficientes).

Nota-se que os ganhos com sortimento seriam maiores (em termos percentuais e absolutos) no varejo e os ganhos com reposição seriam maiores na indústria, a grande beneficiária da adoção do ECR. Com esses resultados tem-se uma demonstração da importância da adoção do ECR como ferramenta de ganho de eficiência e como motivo para a gestão da cadeia de suprimentos.

Tabela 2. Resultados projetados de economias esperadas com a adoção do ECR.

\begin{tabular}{lccc} 
& \multicolumn{3}{c}{$\%$} \\
\cline { 2 - 4 } & Indústria & Varejo & Total \\
\cline { 2 - 4 } Sortimento & 22 & 22 & 44 \\
Introdução & 15 & 0 & 15 \\
Reposição & 24 & 17 & 41 \\
Total & 61 & 39 & 100 \\
\hline & & US\$ milhões & \\
\cline { 2 - 4 } & Indústria & Varejo & Total \\
Sortimento & 986 & 1.019 & 2.005 \\
Introdução & 661 & 0 & 661 \\
Reposição & 1.112 & 772 & 1.884 \\
Total & 2.759 & 1.791 & 4.550 \\
\hline
\end{tabular}

Fonte: www.abrasnet.com.br/ecr-brasil

A tabela 3 apresenta uma comparação dos resultados projetados de economias com a adoção do ECR em regiões selecionadas. Pode-se notar que no caso brasileiro a projeção de economias (em termos percentuais) supera até mesmo as melhores práticas 
internacionais, como os Estados Unidos, líder na adoção do ECR, e a União Européia, primeira seguidora nesta tecnologia.

Tabela 3. Comparativo entre os resultados projetados de economias com a adoção do ECR no Brasil e as economias observadas em regiões selecionadas.

\begin{tabular}{cccccc}
\hline Base (US\$ bi) & Economia (US\$ bi) & $\%$ & Ano & Local & Autor \\
\hline 350,00 & 30,00 & 8,57 & 1993 & EUA & KSA \\
35,00 & 1,80 & 5,32 & 1995 & Argentina & Pwcoopers \\
572,00 & 33,00 & 5,70 & 1996 & Europa & Pwcoopers \\
47,00 & 4,55 & 9,78 & 1998 & Brasil & Pwcoopers \\
\hline
\end{tabular}

Fonte: www.abrasnet.com.br/ecr-brasil

Observa-se que adotando-se as mesmas metodologias em regiões diferentes temse que o potencial de redução de custos do ECR no Brasil chega a ser maior do que o das melhores práticas internacionais (em termos percentuais). $O$ estudo da Pricewaterhouse Coopers revela ainda que grande parte da economia a ser obtida representa a eliminação de tarefas que não agregam valor à distribuição, como excesso de atividades burocráticas e de negociações intermediárias ${ }^{13}$.

No entanto, ressalta-se novamente o caráter incipiente do Programa ECR Brasil. Assim, reside na especificidade da estrutura da cadeia de suprimento de alimentos no Brasil, a possibilidade de se alcançar o resultado projetado. A especificidade da estrutura da cadeia de suprimento refere-se, no caso deste trabalho, à adaptação do setor supermercadista em relação aos pré-requisitos do ECR.

Pretende-se discutir no próximo item a padronização a que se refere este trabalho e a questão da coordenação de cadeias de suprimento, bem como as relações específicas com a cadeia de suprimento de carne bovina in natura no Brasil. Adianta-se que conceitualmente a padronização e a coordenação estão intimamente relacionadas, e que

\footnotetext{
${ }^{13}$ Como exemplo, numa cadeia de suprimento antes da adoção do ECR um comprador numa rede varejista toma cerca de 2,7 decisōes por minuto, o que poderia ser drasticamente reduzido com a implantação de ferramentas do ECR, como o Gerenciamento de Categorias.
} 
a cadeia de suprimento de carne bovina in natura apresenta problemas no que se refere a ambos os conceitos.

\subsection{A padronização e a coordenação de cadeias de suprimento}

Dentro do Programa ECR Brasil foram definidas quinze metas para a padronização: a unitização de cargas, os códigos de barras, o EDI no transporte, a entrega programada, os veículos de transporte de carga, o fluxo de paletes, a legislação, as embalagens de embarque, o cálculo de frete, os indicadores de desempenho, os lacres e a segurança na cadeia de abastecimento, os equipamentos de exibição, a nota fiscal, os equipamentos de movimentação e a desburocratização.

Dentro destas quinze metas, os códigos de barras, a entrega programada e os veículos de transporte de carga são as que se encontram em estágio mais avançado. Dessa forma, esse trabalho pretende enfocar essas metas na pesquisa junto aos supermercados. Assim, quando se fala na metodologia sobre as variáveis de padronização, estas se referem ao nível de conhecimento e de implantação dessas metas do programa nos supermercados da amostra.

Além desse conceito prático de padronização, definido no escopo do Programa ECR Brasil, tem-se também uma abordagem teórica, explícita ou implícita em textos de teoria econômica. No limite, temos a abordagem teórica clássica do funcionamento dos mercados. Para autores dessa linha, como Adam Smith (1776), citado em Farina (1999), o funcionamento dos mercados via sistema de preços ocorreria devido à especialização econômica. Tal especialização, ao dividir socialmente o trabalho, tornaria necessária a troca das "especialidades" no mercado, de forma a atender às necessidades de bem-estar.

Um problema que surgiria então é o da separação geográfica entre produção e consumo, pois a troca de especialidades só poderia ocorrer quando se conhecesse a característica exata dos produtos a serem trocados. Este problema relaciona-se implicitamente à padronização. Estaria implícito no trabalho de Adam Smith que para 
haver o funcionamento do mercado pelo sistema de preços deveríamos observar mercadorias com características comuns e conhecidas por todos os interessados, o que é o objetivo da padronização.

Portanto, o conceito de eficiência neoclássica, estaria intimamente relacionado à padronização a que se refere este trabalho, jả que permitiria a comoditização dos produtos e o funcionamento do mercado via sistema de preços, eliminando problemas como externalidades negativas e informação assimétrica.

David e Greenstein (1990), citado em Farina (1999), definem padrão como um conjunto de especificações técnicas, às quais adere um produtor voluntária ou compulsoriamente, tácita ou formalmente. As especificações cumprem quatro funções básicas:

a) referência (redutora de custos de transação);

b) compatibilidade (redutora de custos de coordenação);

c) base mínima para garantir um nível de eficiência social que o mercado não pode atender em certos casos;

d) base para a ampliação de externalidades positivas de rede.

No que concerne especificamente à cadeia de suprimento da carne bovina, a padronização insere-se num contexto de segurança dos alimentos. A segurança dos alimentos é a garantia da "aquisição, pelo consumidor, de alimentos de boa qualidade, livres de contaminantes de natureza química (pesticidas), biológica (organismos patogênicos), física (vidros e pedras), ou de qualquer outra substância que possa acarretar problemas à sua saúde" (Hobbs e Kerr, 1992).

A cadeia de suprimento da carne bovina é reconhecidamente afetada por problemas de assimetria de informações, conforme definida por Akerlof (1970). Neste sentido, com a crescente pressão da legislação e por parte de demanda no sentido de se garantir a segurança dos alimentos têm surgido diferentes estratégias de coordenação de cadeias de suprimento agroindustriais. 
No caso do Brasil, a principal pressão existente até o momento vem da União Européia, que após as ocorrências da doença da vaca louca passou a exigir dos países fornecedores de carne bovina um sistema de rastreamento da produção, visando um maior controle sanitário e de qualidade ${ }^{14}$. Com a implantação e o desenvolvimento do Programa ECR Brasil, visando a gestão de cadeias de suprimento, pode surgir também uma fonte interna de pressão por readaptações do sistema agroindustrial da carne bovina no que se refere à adoção de estratégias de coordenação.

As estratégias que vêm ganhando maior ênfase são a padronização, a certificação e a rastreabilidade. A padronização, a mais genérica das três, baseia-se na adoção de padrões de referência, facilitando a coordenação entre o consumidor e o ofertante, ao reduzir os custos de aquisição da informação sobre os produtos e ao limitar as situações sujeitas ao chamado "risco moral" (moral hazard), criadas pela falta de informação dos compradores e pela possibilidade de que os vendedores dissimulem problemas de qualidade. "O padrão de referência firma certas características do produto com vistas a assegurar as propriedades de reprodutibilidade, de equivalência e de estabilidade adequadas às condições de produção e mudança de um sistema industrial. Graças ao padrão de referência, o produto é identificado, suas qualidades e seu desempenho são certificados e sua evolução previsível" (Mathias, 1998, p. 37).

A certificação é uma forma concorrente da padronização do ponto de vista de coordenação de sistemas agroindustriais, tratando-se de uma padronização mais detalhada, com instrumentos de exclusão daqueles que não seguirem as regras. Além disso, a certificação é um instrumento mais dinâmico porque pode ser feita no nível das firmas, das associações privadas, do governo nacional e por instituições internacionais.

Em última instância encontra-se a rastreabilidade. O objetivo da rastreabilidade é "garantir ao consumidor um produto seguro e saudável, por meio do controle de todas as fases da produção, industrialização, transporte/distribuição e comercialização, possibilitando uma perfeita correlação entre o produto final e a matéria prima que the deu origem" (Lombardi, 1998, p. 90).

\footnotetext{
${ }^{14}$ A comprovação da origem do produto é feita pelo logotipo Brazilian Beef (Lombardi, 1998).
} 
A implantação do sistema consta em rotular a carne até o consumidor final a fim de garantir um produto seguro (Lombardi, 1998). A rotulagem deve ser feita por uma etiqueta no produto contendo as seguintes informações (Beloto, 1998 e Lombardi, 1998):

- Nome e endereço do estabelecimento produtor;

- Número do controle sanitário (número SIF);

- País onde o animal nasceu, foi criado, engordado e abatido;

- Tipo de criação e alimentação;

- Tipo de produto;

- Nome do corte;

- Data de produção e data de validade;

- Código de rastreabilidade que corresponde ao número do estabelecimento de abate (SIF), data de abate, número do lote, sexo e idade aproximada do animal.

Segundo Farina (1999), a padronização pode ser imposta pelo governo, associações profissionais ou por firmas dominantes. Kindleberger (1983) afirma que a imposição pelo governo seria a solução ótima já que os padrões são encarados como bens públicos, na medida em que estão sujeitos às características de não-rivalidade e não-exclusãa ${ }^{15}$ já que estão disponíveis para o uso de todos e o uso por um agente econômico não reduz o montante disponível para os demais e, além disso, estão sujeitos a economias de rede: quanto maior o número de produtores e consumidores que utilizam um dado padrão, maiores os ganhos obtidos por usuários adicionais, dados os ganhos em comparabilidade e intercambialidade.

Nessas condições, diz a teoria microeconômica tradicional que o investimento privado tende a ser inferior ao que seria desejável socialmente, na medida em que os

15 Por exemplo, padróes de medida, tais como peso, temperatura, tempo, valor (função de unidade de conta da moeda) 
benefícios gerados pela elaboração e implementação de padrões não podem ser apropriados em sua totalidade pelo agente privado. No entanto, este mesmo autor chama a atenção para $o$ fato de que a maior parte da padronização foi originalmente desenvolvida e implementada por comerciantes privados.

Conforme Farina (1999), "parte do valor agregado por centros de comercialização de produtos básicos como o de Amsterdã, nos séculos XVII e XVIII, decorria das atividades de separação, classificação, embalagem e armazenagem dos produtos trazidos ao entreposto. $\mathrm{O}$ comerciante tinha um forte interesse em assegurar que os produtos fossem selecionados de acordo com a classificação e qualidade demandada pelos clientes, por uma simples razão: naquela época, os produtos eram vendidos em feiras que ocorriam a cada três ou seis meses ou embarcados em comboios anuais e produtos rejeitados pelos destinatários significavam imobilização do capital por um período mais longo de tempo". (Farina, 1999, p. 9).

No caso da imposição de padrões a partir de empresas privadas, esta terá impactos tanto mais amplos quanto maior seu domínio do mercado. Segundo Farina (1999), "fornecedores potenciais tendem a adotar voluntariamente padrões que sejam exigidos por empresas dominantes, de forma a ter acesso a mercados. As grandes redes de supermercados poderiam atuar como esse agente difusor de padrões". (Farina, 1999, p.9).

A rede de supermercados francesa Carrefour criou um sistema próprio de coordenação do fornecimento de carne bovina, nos moldes da gestão de cadeias de suprimento e do ECR, chamado "Cadeia da Qualidade" (Filière Qualité Carrefour). Este sistema permite que o supermercado controle a origem da carne bovina comercializada ao criar seis canais de fornecimento baseados na raça do animal e na região de origem (Charolais, Limousin, Blonde d'Aquitaine, Abondance, Normande e Montbéliarde). A efetivação dessas cadeias de qualidade permitiu o monitoramento da ação dos chefes de compra e uma grande homogeneização da oferta.

No Brasil o Carrefour ainda não implantou completamente tal estratégia, mas já 
tem conseguido avanços significativos ${ }^{16}$. Com a difusão do ECR no Brasil sendo conduzida pelos supermercados, tem-se que aumentam as chances de se ter a generalização da prática de gestão de cadeias de suprimento.

Além da pressão da União Européia, surgiram no Brasil dois exemplos de sistemas de rastreabilidade e de padronização: a Aliança Mercadológica da Carne e o Programa da Carne com Qualidade do Rio Grande do Sul.

Segundo Jank (1999), “ambos já evoluíram para a garantia de origem, mas ainda não permitem a identificação do animal. No caso da Aliança, é possível rastrear a carne até o lote de determinado produtor. O sistema seria perfeitamente rastreável se já permitisse identificar o animal".(Jank, 1999, p. 39).

A experiência da Aliança Mercadológica para a carne bovina no estado de São Paulo (Programa de Qualidade Total) é coordenada pelo FUNDEPEC, o Fundo de Desenvolvimento da Pecuária do Estado de São Paulo. Trata-se de um subsistema agroindustrial estritamente coordenado que envolve pecuaristas, frigoríficos e supermercados selecionados na coordenação da cadeia da distribuição do novilho precoce.

De acordo com Beloto (1998), citado em Jank (1999), “a seleção do gado é feita no local de produção, onde são conhecidas e identificadas as seguintes características: raça, composição genética do novilho, alimentação, manejo e calendário profilático. No frigorífico, os novilhos são tipificados, classificados e coletados os dados de carcaça pelo Sistema BERTIN de tipificação adaptado à Aliança Mercadológica. Após a tipificação, o FUNDEPEC atribui um selo de qualidade, que garante que a carne é oriunda de novilhos precoces. Essa carne vai ao supermercado certificada, onde é oferecida ao consumidor".(Jank, 1999, p. 39).

Ainda segundo estes autores, "a Aliança Mercadológica foi criada para rastrear e

\footnotetext{
${ }^{16}$ A rede francesa já está num processo adiantado de construção de um centro de desossa e preparação de carne bovina, que permitirá uma centralização dessa atividade e um maior controle sobre a oferta. Além disso, vem mantendo sob coordenação estrita a produção de cerca de 30.000 cabeças de gado para corte, visando implantar uma estratégia de Filière Qualité para a carne bovina no Brasil. Ver no anexo D o detalhamento sobre a Filière Qualité.
} 
certificar carnes bovinas de qualidade. Por isso, seus idealizadores escolheram o novilho precoce como animal típico. A experiência mostrou que a qualidade intrínseca da carne não é garantida apenas pela idade de abate do animal. Assim, o selo garante uma carne sadia com origem conhecida, mas não necessariamente o padrão perfeito, a maciez e o sabor do produto. A criação de um sistema perfeitamente rastreável é uma evolução natural desse sistema de certificação".(Jank, 1999, p. 39).

Enquanto no caso do Carrefour francês a rastreabilidade (e a demanda por padronização) vai do consumidor ao produtor, o sistema da Aliança Mercadológica vai no sentido contrário: parte do pecuarista para o supermercado. Apesar de ser aceito que um sistema começando no produtor também pode dar certo, há claras dificuldades em criar incentivos para a participação dos supermercados e frigoríficos. Se as exigências fossem do supermercado, os frigorificos teriam menor poder de barganha e tenderiam a se enquadrar mais fácil e rapidamente no sistema (Jank, 1999).

Outra especificidade da Aliança é o problema da criação de canais exclusivos dentro do frigorífico e a grande diferença entre o produto oferecido pelo pecuarista, que é o boi em pé, e o produto desejado pelo consumidor, que são cortes específicos padronizados, desossados e embalados. Para Jank (1999), "sempre ocorre variabilidade no boi produzido e o sistema de padronização é ineficiente para classificar as carcaças e remunerar os padrões superiores. De nada adianta a produção de um novilho precoce se sua carne for misturada com carnes de outros animais no frigorífico. Não há como rastrear a carne até seu animal de origem se, no momento da desossa, dentro do frigorifico, carnes de diferentes animais forem misturadas. A rastreabilidade perfeita necessita que a carne saia embalada do frigorífico com uma rotulagem que identifique 0 animal de origem" (Jank, 1999, p.40).

Diante dos conceitos relacionados à padronização e à cootdenação de sistemas agroindustriais apresentados, verifica-se que das tentativas de se realizar uma gestão de cadeias de suprimento, como o caso da Aliança Mercadológica e do Programa da Carne com Qualidade e o caso do Carrefour, nenhuma se insere nos moldes do ECR. O ECR propõe uma gestão de cadeias de suprimento partindo do varejo e caminhando para o 
produtor, com o estabelecimento de procedimentos estáveis e padronizados de comercialização.

No caso dos dois primeiros exemplos (Aliança Mercadológica e Programa da Carne com Qualidade), avança-se em termos do estabelecimento de procedimentos estáveis e padronizados de comercialização, mas recua-se em termos de coordenação a partir do varejo. No caso do último exemplo (Carrefour), avança-se em termos de coordenação a partir do varejo, mas recua-se em termos do estabelecimento de procedimentos estáveis e padronizados universais de comercialização ${ }^{17}$.

\subsection{A cadeia de suprimento da carne bovina}

Quanto aos fornecedores de insumos à produção primária, tem-se a indústria de produtos veterinária (vacinas, medicamentos, complementos nutricionais), as empresas de sementes e forrageiras, equipamentos, fornecedores de sêmen, além de outros serviços (ver anexo E para um detalhamento da cadeia de suprimento da carne bovina).

Na produção primária destaca-se o sistema extensivo, em regime de pasto, com pastagens naturais ou cultivadas, incorporando as fases de cria, recria e engorda. "A cria engloba os bezerros até a desmama, ou até um ano de idade e os touros, vacas e novilhas em idade de cobrição. A recria inicia-se com um ano e termina quando as fêmeas atingem a idade de reprodução ( 2 a 3 anos) e os machos atingem o desenvolvimento necessário para a engorda. A engorda consiste na fase final de preparo para $\mathrm{o}$ abate $\mathrm{e}$ normalmente dura 1 ano".(Bliska e Gonçalves, 1998, p. 167).

O importante a se notar sobre a produção primária é que o manejo não obedece a critérios adequados de alimentação, diferenciados por categoria de animal, o que afeta

\footnotetext{
17 "Os supermercados foram os primeiros agentes da cadeia do agribusiness a perceber que a qualidade é um bom negócio. O Carrefour multiplicou por cinco as quantidades vendidas de frango e camarão depois que adotou o selo de garantia de origem. No Brasil, por enquanto, o selo da companhia está avaliando a qualidade de dez produtos, mas a perspectiva é ampliar seu uso para todos os perecíveis nos próximos 24 meses. No Pão de Açúcar, o selo foi criado em junho e abrange toda a linha de carnes e derivados". (O Estado de S. Paulo, 11/10/1999).
} 
diretamente o nível de produtividade do rebanho. "Por exemplo: o manejo reprodutivo utiliza-se freqüentemente da estação de monta no período de setembro a janeiro (estação de monta natural), assim, o final da gestação, o parto e o início da lactação, fases em que a necessidade nutricional do animal aumenta, ocorrem em períodos de baixa disponibilidade e qualidade de pastagens".(Bliska e Gonçalves, 1998, p.168).

No abate e processamento atuam estruturas como os matadouros e os matadouros-frigoríficos. Os matadouros, unidades operacionais de pequeno porte e rudimentares, trabalham sem túnel de congelamento, sendo o produto fresco, refrigerado ou in natura comercializado para consumo imediato, na própria região de influência. Neste tipo de estrutura, não há inspeção sistemática de condições sanitárias e de pagamento de impostos, o que permite de certa forma uma sobrevida a estas firmas, que atuam na clandestinidade.(Peetz et. al., 1996).

Os matadouros-frigorificos, por sua vez, são unidades operacionais mais completas, dotadas de equipamentos modernos, onde o controle da matéria-prima, o processamento, estocagem e distribuição são gerenciados sob moldes empresariais e operam sob inspeção sanitária e fiscalização de impostos (Bliska e Gonçalves, 1998).

No geral, a fase de abate e processamento apresenta estas caracteristicas gerais, retiradas de Bliska e Gonçalves (1998):

1) baixa valorização do aspecto qualitativo;

2) os incentivos ao produtor na transação com o frigorífico e os incentivos fiscais ao abate de bovinos jovens constituem-se nas duas alternativas de melhoria da qualidade;

3) a carne produzida destina-se na sua grande parte para o mercado interno

4) a comercialização de cortes in natura responde por cerca de $85 \%$ dos abates;

5) as exportadoras possuem elevado nível tecnológico;

6) o único critério que vem sendo utilizado para diferenciar a carne bovina é o pagamento diferenciado pelo abate de boi e vaca, com uma redução entre $10 \%$ e $15 \%$ no 
preço da vaca;

7) eventualmente o frigorifico paga um pouco mais ao pecuarista que tradicionalmente possui animais que rendem mais couro, carcaça e outros subprodutos, mas o pecuarista não sabe qual o rendimento de seu animal;

8) a desossa ocorre cada vez mais nos frigoríficos, devido principalmente ao distanciamento da produção primária e do consumo e à nova regulamentação governamental de 1996 (exigência do SIF) ${ }^{18}$;

9) presença de iniciativas isoladas e desarticuladas em busca da qualidade e da padronização da matéria-prima, ao contrário dos processadores da cadeia de frangos e suínos, que buscam uma integração cada vez maior com a produção primária.

Segundo De Zen (1998), a partir das pressões ocorridas sobre a receita dos frigoríficos, estes têm buscado formas de melhoria do fluxo de caixa, sendo uma das principais saídas a desossa da carcaça. A receita dos frigorificos caiu de $\mathrm{R} \$$ 200,00/cabeça, em 1986, para R\$ 50,00/cabeça em 1998.

A desossa permite ao frigorífico uma maior flexibilidade nos preços de venda, apesar de que a afirmação de aumento das margens não seja válida para este autor, devido ao desconhecimento do custo da desossa. Além disso, aumenta a flexibilidade em custos, já que o transporte pode ser feito no mesmo veículo com um ganho de $20 \%$ na quantidade transportada.

Ainda para este autor, é uma tendência a aproximação entre produtor e frigorífíco visando diminuir os problemas já citados referentes à assimetria de informações e de padronização de produtos e processos. É citada também a importância crescente do canal de distribuição via supermercados, que representaria hoje cerca de $40 \%$ do total comercializado.

Como vantagem da carne desossada ainda é citado: "a carne desossada e

\footnotetext{
${ }^{18}$ Cita-se como vantagens da desossa: redução do custo de frete por tonelada de carne transportada, maior controle sanitário, aumento da arrecadação tributária e redução do custo do sistema de distribuição. Além disso, acredita-se que a desossa amplia o potencial do ECR e das estratégias de coordenação em geral.
} 
embalada a vácuo possibilita maior flexibilidade na distribuição, ou seja, o frigorifico tem prazo maior para colocar a carne no mercado. O comércio varejista também pode controlar melhor a sua compra e pode escolher os cortes de acordo com seu público consumidor. Com isso, por exemplo, uma loja situada em região de baixa renda não precisa liquidar filet mignon quando ele está sobrando, apenas não vai comprá-lo. Tratase da racionalização do processo, em que a loja deixa de perder receita com a carne 'encalhada' e pode oferecer aos seus fregueses aquilo que eles querem. Por outro lado, aumentam as ofertas de filet mignon onde existe demanda para esse corte" (De Zen, 1998, p.541).

A partir dessas opiniões, conclui-se que existem pressões econômicas sobre a fase do processamento de carne no sentido de uma maior adoção de procedimentos padronizados e estáveis, ou seja, para um gerenciamento da cadeia de suprimento integrada nos moldes do ECR.

No que tange ao varejo, as estimativas apontam para uma distribuição heterogênea no que se refere ao tipo de corte. Para cortes de primeira, estima-se que os supermercados detêm cerca de $45 \%$ da distribuição. Já para cortes de segunda, esta estimativa cai para cerca de 30\%. (De Zen, 1998, p. 541) Contudo, "a preferência dos consumidores está se deslocando para a aquisição em supermercados, principalmente nas faixas de renda média e em grandes centros urbanos. Isto é também observado nos países mais desenvolvidos, o que leva a crer que a tendência se manterá no futuro".(De Zen, 1998, p.541).

Estimativas realizadas apontam que o consumo de carne bovina tem altas elasticidades-renda para faixas de baixa renda e que esta elasticidade cai à medida que a faixa de renda aumenta. (De Zen, 1998, p.543) Assim, a promoção de políticas de distribuição de renda faria com que houvesse um aumento significativo da demanda de carne bovina. Mesmo com a inexistência de tais políticas, a própria estabilização de preços, ao manter relativamente estáveis os preços relativos da economia (salários/preços/câmbio), garantem um aumento do consumo da carne bovina.

Segundo a reportagem da revista Super Hiper (1999), referindo-se ao açougue do 
supermercado, "a seção é uma das mais importantes para a formação de imagem da loja diante dos olhos dos consumidores. Exerce papel de atração de clientes e contribui com boa parcela do faturamento. Cuidar bem dessa área é investimento com retorno garantido".(Super Hiper, 1999, p.32) A reportagem cita ainda que "a diminuição nos custos indiretos da seção, redução no índice de perdas, economia de refrigeração, melhoria no controle do recebimento e de resultados são algumas das vantagens da operação com carne desossada. Isso tudo sem contar o aspecto da higiene, já que a manipulação do produto é bem menor, o que reduz as chances de contaminação. Outro benefício é a eliminação de resíduos, como osso e sebo" (Super Hiper, 1999, p.33).

Deve-se ressaltar que essa tendência à padronização através da comercialização de carne desossada e embalada no fornecedor, ou em uma etapa anterior à entrada na loja, não é recente. Na reportagem da revista Supermercado Moderno (1992) tem-se que "quando se observa esta importante seção dos supermercados, nota-se que seu destino infalível é eliminar o trabalho braçal pesado, valorizar o tempo, padronizar processos e produtos, gastando menos com mão-de-obra, energia elétrica, manutenção, etc." (Supermercado Moderno, 1992, p.38).

Além da constatação de economias do ponto de vista técnico, a lógica da preferência do consumidor também aponta para uma padronização no ponto de venda. Numa pesquisa da revista Supermercado Moderno foi revelado que a maior vantagem dos pontos de venda tradicionais (açougues) sobre os supermercados é a característica da came comprada com excelente qualidade e cortada exatamente como desejado. (Supermercado Moderno, 1992, p.42) Assim, a venda de carne pré-cortada e embalada poderia não ser indicada.

Contudo, é elevado o crescimento de vendas das chamadas boxed beefs e consumer units ${ }^{19} \mathrm{em}$ supermercados, além do que "do lado dos supermercados, que caminham mais aceleradamente na modernização de suas instalações, é nítida a preferência por diminuir o espaço de seus açougues, reduzindo o processamento e dando

\footnotetext{
19 Boxed beefs são carnes desossadas pelos fornecedores, mas cortadas e embaladas pelo supermercado. Consumer units são carnes desossadas, cortadas e embaladas pelos
} 
às carnes o mesmo tratamento de outros produtos, ou seja, expô-las embaladas, nas gôndolas" (Faveret Filho e de Paula, 1997, p. 107). Ressalta-se que o atributo de qualidade identificado pelo consumidor nos açougues em relação aos supermercados é questionável pois, na ausência de uma razoável rastreabilidade do produto, não se pode afirmar nada sobre a qualidade da carne. Já em relação ao corte há uma indicação da grande importância atribuída a esta prática, que permitiria uma maior flexibilidade para o consumidor no momento da compra.

As boxed beefs seriam o que se chama neste trabalho de fronteira tecnológica possivel e as consumer units seriam a fronteira tecnológica limite na venda de carne bovina in natura em supermercados.

As características da cadeia de suprimento da carne bovina apresentadas neste tópico permitem, portanto, afirmar que existe uma crescente pressão por padronização de processos, partindo principalmente do seu elo final, os supermercados, que cada vez mais ganham importância como ponto de venda desse produto.

fornecedores, cabendo ao supermercado apenas a exposição na gôndola. 


\section{METODOLOGIA}

\subsection{Amostra}

A amostra foi definida a partir do tamanho das lojas dos supermercados. O tamanho de uma loja pode ser definido segundo inúmeras variáveis (área de vendas, número de funcionários, faturamento, número de check-outs). Devido à disponibilidade de informações a respeito destas variáveis, foi escolhido o número de check-outs das lojas como sendo a proxy para o tamanho.

Tabela 4. Definição da estratificação da amostra com base na participação da cada estrato de tamanho no total de lojas (check-outs) constantes na população (ranking da ABRAS).

\begin{tabular}{lccc}
\hline $\begin{array}{c}\text { Tamanho } \\
\text { (no de check-outs) }\end{array}$ & $\mathrm{N}^{\circ}$ de lojas (\%) & Classificação por porte & $\%$ da amostra \\
\hline Até 9 & $57,69 \%$ & Pequeno/Médio & $57,69 \%$ \\
De 10 a 19 & $28,88 \%$ & Médio & $28,88 \%$ \\
20 ou mais & $13,43 \%$ & Grande/Hiper & $13,43 \%$ \\
\hline
\end{tabular}

Fonte: Super Hiper / Nielsen. Serviços de marketing, set/96

Foram obtidas duas listagens de supermercados. Para o estado de São Paulo, a listagem dos supermercados foi obtida junto à Associação Brasileira de Supermercados (ABRAS). Para a Região Metropolitana de Belo Horizonte, a listagem dos supermercados foi obtida junto à Associação Mineira de Supermercados (AMIS). A 
definição dos estratos de tamanho atende ao critério definido pela ABRAS, conforme a tabela 4, e a amostra segue a proporcionalidade em relação ao percentual de lojas de cada estrato.

A população da pesquisa é formada pelos supermercados do estado de São Paulo que constam no cadastro da ABRAS e pelos supermercados da Região Metropolitana de Belo Horizonte que constam no cadastro da AMIS. A escolha do estado de São Paulo deve-se ao fato de que ele tem participação expressiva em todos os possíveis indicadores de tamanho de firmas supermercadistas, conforme apresentado na tabela 5.

Tabela 5. Indicadores de tamanho - Comparativo São Paulo X Ranking ABRAS 1998.

\begin{tabular}{lrrrrr}
\hline & $\begin{array}{r}\text { Faturamento } \\
(\mathrm{RS} \mathrm{mi})\end{array}$ & $\begin{array}{r}\text { Check-outs } \\
\left(\mathrm{N}^{\circ}\right)\end{array}$ & $\begin{array}{r}\text { Área de } \\
\text { Vendas }\left(\mathrm{m}^{2}\right)\end{array}$ & $\begin{array}{r}\text { Lojas } \\
\left(\mathrm{N}^{\circ}\right)\end{array}$ & $\begin{array}{r}\text { Funcionários } \\
\left(\mathrm{N}^{\circ}\right)\end{array}$ \\
\hline São Paulo (A) & $16.444,74$ & 14.938 & 1.723 .773 & 955 & 95.676 \\
Ranking ABRAS (B) & $36.058,82$ & 42.282 & 4.499 .460 & 3.834 & 276.046 \\
$(\mathrm{~A}) /(\mathrm{B})$ & $46 \%$ & $35 \%$ & $38 \%$ & $25 \%$ & $35 \%$ \\
\hline
\end{tabular}

Fonte: ABRAS (1998)

A inclusão da Região Metropolitana de Belo Horizonte deve-se à possibilidade de aumento no tamanho da amostra, já que o teste de hipótese do trabalho não se relaciona a disparidades regionais.

Foram entrevistadas, aleatoriamente, 37 firmas supermercadistas (lojas) pertencentes ou não a redes de lojas. Apesar do reduzido tamanho da amostra, na tabela 6 tem-se um real dimensionamento desta em relação à população pesquisada.

Quanto à proporcionalidade proposta na tabela 4, tem-se uma comparação com a proporcionalidade seguida pela amostra na tabela 7 . Percebe-se que a amostra segue a proporcionalidade proposta, com algum viés para o estrato de lojas pequenas/médias e médias.

Tal viés pode ser desconsiderado já que o ranking da ABRAS apresenta um viés considerável favoravelmente ao estrato de lojas grandes/hiper, já que praticamente a 
totalidade destas está cadastrada na associação setorial, enquanto um grande número de lojas médias e pequenas/médias não é encontrado nos registros desta associação.

Tabela 6. Dimensionamento da amostra em relação ao tamanho da população

\begin{tabular}{|c|c|c|c|c|c|}
\hline \multicolumn{6}{|c|}{ São Paulo } \\
\hline $\begin{array}{l}\text { Total de firmas } \\
\text { (A) }\end{array}$ & $\begin{array}{l}\text { Contatadas } \\
\text { (B) }\end{array}$ & $\begin{array}{l}\text { Participantes } \\
\text { (C) }\end{array}$ & (B) $/(\mathrm{A})$ & $(\mathrm{C}) /(\mathrm{A})$ & (C) $/(\mathrm{B})$ \\
\hline 122 & 99 & 33 & $81,15 \%$ & $25,41 \%$ & $31,31 \%$ \\
\hline \multicolumn{6}{|l|}{ Belo Horizonte } \\
\hline $\begin{array}{l}\text { Total de firmas } \\
\text { (A) }\end{array}$ & $\begin{array}{l}\text { Contatadas } \\
\text { (B) }\end{array}$ & $\begin{array}{l}\text { Participantes } \\
\text { (C) }\end{array}$ & (B) / (A) & (C) $/(\mathrm{A})$ & (C) $/(\mathrm{B})$ \\
\hline 51 & 26 & 4 & $50,98 \%$ & $7,84 \%$ & $15,39 \%$ \\
\hline
\end{tabular}

Fonte: Pesquisa de campo.

Tabela 7. Comparação da proporcionalidade de número de lojas participantes com o número total de lojas de cada estrato na população.

\begin{tabular}{llllll}
\hline Pequeno/Médio & \multicolumn{2}{l}{ Médio } & \multicolumn{2}{l}{ Grande/ Hiper } \\
\hline $\begin{array}{l}\mathrm{N}^{\circ} \text { de Lojas Amostra (\%) } \\
(\%)\end{array}$ & $\begin{array}{l}\mathrm{N}^{\circ} \text { de Lojas Amostra (\%) } \\
(\%)\end{array}$ & $\begin{array}{l}\mathrm{N}^{\circ} \text { de Lojas Amostra (\%) } \\
(\%)\end{array}$ \\
\hline $57,69 \%$ & $69,44 \%$ & $28,88 \%$ & $19,44 \%$ & $13,43 \%$ & $11,11 \%$ \\
\hline
\end{tabular}

Fonte: Pesquisa de campo.

No caso das participantes do estado de São Paulo, o contato foi por meio de telefonema direto ao gerente das lojas. Foi solicitada a resposta ao formulário da pesquisa e, quando o gerente encontrava-se impossibilitado de responder no momento (a quase totalidade das vezes), $o$ formulário foi enviado por fax, juntamente com uma folha de rosto solicitando o retorno deste formulário. A tabela 8 apresenta alguns números da pesquisa em São Paulo. 
Tabela 8. Informações operacionais sobre a pesquisa de campo no estado de São Paulo.

\begin{tabular}{cccccc}
\hline \multicolumn{2}{c}{ Ligações } & \multicolumn{2}{c}{ Transmissões de Fax } & \multicolumn{2}{c}{ Custo direto } \\
\hline Número & Tempo & Número & Tempo & Total & Médio \\
médio & médio & médio & médio & estimado & \\
\hline 3 & $1 \operatorname{min~} 30 \mathrm{~s}$ & 1 & $1 \min 50 \mathrm{~s}$ & $\mathrm{R} \$ 400,00$ & $\mathrm{R} \$ 11,76$ \\
\hline
\end{tabular}

Fonte: Pesquisa de campo.

No caso das participantes da Região Metropolitana de Belo Horizonte, o contato foi por meio de visita às lojas e entrevistas realizadas diretamente com os gerentes das lojas. Por impossibilidade momentânea de resposta, alguns gerentes preferiram retornar o formulário por fax, o que contribuiu para o baixo índice de resposta da pesquisa nesta região. Contudo, ganhou-se de certa forma no aspecto qualitativo da informação já que, ao visitar as lojas, foi possível avaliar pessoalmente a situação dos açougues e das próprias lojas (no aspecto tecnológico).

Estes números servem para comprovar o trade off "qualidade da informação $\mathrm{x}$ preço da informação" e, no caso desta pesquisa, a ineficácia da estratégia de visitas pessoais, já que neste caso o índice de resposta foi muito mais reduzido. $O$ gerente de lojas de um supermercado toma decisões a todo instante (recebimento de mercadorias, conferência, exposição, preços, compra, renegociação de espaço nas gôndolas, promoções, pessoal, atendimento ao público) o que limita sobremaneira a sua disponibilidade para participar de uma pesquisa de interesse particular. A tabela 9 apresenta alguns números da pesquisa nesta região.

Tabela 9. Informações operacionais sobre a pesquisa de campo na RMBH.

\begin{tabular}{ccccc}
\hline \multicolumn{2}{c}{ Visitas realizadas } & Km percorridos & \multicolumn{2}{c}{ Custo direto } \\
\hline Lojas & Lojas válidas & Estimado & Total estimado & Médio \\
\hline 197 & 51 & 500 & R\$ 120,00 & R\$ 30,00 \\
\hline
\end{tabular}

Fonte: Pesquisa de campo. 
As lojas válidas são lojas que são equipadas com açougue. As outras 146 lojas visitadas não possuem esta seção disponível. Isto ocorre porque há um grande número de pequenos estabelecimentos com menos de dois check-outs e área menor do que 200 $\mathrm{m}^{2}$, as "mercearias de bairro" que estão cadastradas como supermercados no ranking da ABRAS por possuírem as outras seções de uma loja deste tipo (mercearia, padaria, frutas, legumes e verduras).

\subsection{Questionário}

A fonte de informações para que as hipóteses fossem testadas a fim de se atingir os objetivos foram as entrevistas orientadas por um questionário estruturado com questões fechadas, com o mesmo questionário sendo aplicado para todas os supermercados. As entrevistas foram realizadas diretamente com os gerentes das lojas das redes escolhidas ou com o responsável direto pelo setor de carne bovina.

Pretendeu-se captar com o questionário as especificidades ao nível das lojas, já que grandes firmas supermercadistas podem ter lojas que não estejam tão próximas da fronteira de padronização.

O questionário é constituído de quatro partes. A primeira aborda o nível de utilização de alguns elementos de infra-estrutura das lojas para caracterizar as lojas entrevistadas. A segunda, o nível de utilização de novas tecnologias para supermercados. O questionário completo pode ser visto no anexo $\mathrm{F}$.

A terceira pesquisa a existência e a utilização de pré-requisitos para a padronização (variáveis de padronização) na comercialização de carne bovina in natura. Dessa forma pretende-se testar a hipótese um. A tabela 10 apresenta as questões dessa parte, que serão utilizadas diretamente para o teste da hipótese do trabalho.

Todas as questões são possiveis proxys para a padronização Quanto maiores os níveis de utilização (nas questões de 6 a 14) mais próxima está a loja entrevistada da fronteira tecnólógica de padronização. Além disso, como é um objetivo deste trabalho 
definir um posicionamento das lojas no que se refere à esta fronteira, pretende-se definir quais são as melhores práticas na comercialização de carne bovina in natura. As melhores práticas possíveis serão determinadas pelas proxys que apresentarem os mais elevados níveis de utilização.

Tabela 10. Questões da parte 3 do questionário referentes ao nível de utilização de prérequisitos para a padronização (conceito ECR).

5. No que se refere ao total de carne recebida pela loja por semana, Opções qual o percentual aproximado de recebimento de carne:

5. desossada sem embalagem

6. desossada e embalada em peças pelo fornecedor

1. Até $20 \%$

7. desossada e embalada em cortes prontos pelo fornecedor

2. De 20 a $60 \%$

8. desossada embalada em cortes prontos com marca do fornecedor

3. Mais de $60 \%$

9. desossada embalada em cortes prontos, paletizada.

10. No que se refere ao total de carne manipulada pelo açougue por semana qual o percentual aproximado de venda de carne:

10. embalada em cortes prontos

11. embalada e com código de barras

12. embalada com marca do fomecedor

1. Até $20 \%$

13. embalada com marca do supermercado

2. De 20 a $60 \%$

14. embalada com etiqueta de identificação completa

3. Mais de $60 \%$

Fonte: Questionário da pesquisa de campo.

Assim, pode ser que a proxy "carne desossada embalada em cortes prontos, paletizada" (questão 9), o que seria uma prática de fronteira tecnológica limite no recebimento da carne pela loja segundo as publicações setoriais (Super Hiper e Supermercado Moderno), tenha um nível de utilização muito baixo. Então, esta não seria uma boa proxy para a padronização no recebimento.

Pode ser que a proxy com maior nível de utilização seja "carne desossada e embalada em peças pelo fornecedor" (questão 6). Assim, esta será a fronteira tecnológica possível.

Da mesma forma, pode ser que a proxy "venda de carne embalada com etiqueta de identificação completa" (questão 14), o que seria uma prática de fronteira 
tecnológica limite na venda da carne pela loja segundo as publicações setoriais (Super Hiper e Supermercado Moderno), tenha um nível de utilização muito baixo. Então, esta não seria uma boa proxy para a padronização na venda.

Pode ser que a proxy com maior nível de utilização seja "venda de carne embalada e com código de barras" (questão 11). Assim, esta será a fronteira tecnológica possível na padronização na venda de carne bovina in natura.

A quarta parte pesquisa os hábitos de compra de carne bovina in natura das lojas. A existência e a utilização de pré-requisitos para a coordenação (variáveis de coordenação) entre supermercados e fornecedores será captada nesta parte do questionário. A tabela 11 apresenta as questões dessa parte, que serão utilizadas diretamente para o teste da hipótese do trabalho.

Tabela 11. Questões da parte 4 do questionário referentes ao nível de utilização de pré-requisitos para a coordenação.

22. Gostaria de saber se esta firma pratica ou não:
22. Preferência na descarga aos fornecedores que entregam a carne em horário programado

23. Preços diferenciados aos fornecedores que entregam a carne desossada

24. Preços diferenciados aos fornecedores que entregam a carne pronta para venda

25. Preços diferenciados aos fornecedores que entregam a carne embalada.

26. Preferência na descarga aos fornecedores que entregam a carne paletizada.

27. Preços diferenciados aos fornecedores que identificam a origem da carne.

28. Contrato de fornecimento constando somente o preço.

29. Contrato de fornecimento constando o preço e a frequiência de entrega.

30. Contrato de fornecimento constando o preço, a freqüência de entrega, e exigências sobre a qualidade da carne.

Fonte: Questões da parte 4 do questionário da pesquisa de campo. 
Assim como na parte 3, todas as questões são possíveis proxys para a coordenação. Quanto maiores os níveis de utilização (nas questões de 22 a 30) mais a loja entrevistada coordena os fornecedores.

Da mesma forma que as proxys para a padronização, pode ser que a proxy de coordenação "contrato de fornecimento constando o preço, a freqüência de entrega, e exigências sobre a qualidade da carne (idade do animal abatido, data do abate, etc.)" (questão 30), o que seria uma prática de fronteira tecnológica limite na coordenação de fornecedores, tenha um nível de utilização muito baixo. Então, esta não seria uma boa proxy para a coordenação.

Pode ser que a proxy com maior nível de utilização seja "preferência na descarga aos fornecedores que entregam a carne em horário programado" (questão 22). Assim, esta será a fronteira tecnológica possivel.

\subsection{Tratamento dos dados}

O primeiro e o segundo grupo de variáveis, obtidos na terceira e na quarta parte do questionário, são não-métricos, seguindo a nomenclatura de Sharma (1996). Além disso, não é sabido se há uma relação de dependência entre os três grupos de variáveis (padronização, coordenação e tamanho), o que não permite o uso de modelos econométricos.

Tabela 12. Métodos estatísticos de interdependência.

\begin{tabular}{ccc}
\hline Número de variáveis & \multicolumn{1}{c}{ Tipo dos dados } \\
\cline { 2 - 3 } & Métricos & Não-métricos \\
\hline \multirow{2}{*}{ Mais de 2} & Correlação simples & Tabela de contingência de dois sentidos \\
& $\begin{array}{c}\text { Componente principal } \\
\text { Análise fatorial }\end{array}$ & $\begin{array}{c}\text { Tabela de contingência de múltiplos sentidos } \\
\text { Modelo Loglinear } \\
\text { Análise por correspondência }\end{array}$ \\
\hline
\end{tabular}

Fonte: Sharma (1996), p. 11. 
Assim, a aplicação de técnicas de análise multivariada caminha para métodos como a análise de tabelas de contingência de duplo sentido, indicada para a aplicação em dados não-métricos e em situações onde a relação entre grupos de variáveis não é conhecida. Tal constatação baseia-se na tipologia de métodos estatísticos de interdependência, apresentados na tabela 12.

\subsubsection{A análise de tabelas de contingência}

Este tópico baseia-se no trabalho de Everitt (1992). A análise de tabelas de contingência é a metodologia a ser utilizada para o teste das hipóteses deste trabalho. A escolha dessa metodologia deve-se ao fato de que os testes realizados sobre as informações geradas por tabelas de contingência se adequam sobremaneira aos objetivos deste trabalho. Além disso, é um método simples de se trabalhar e que permite obter conclusões interessantes a respeito da independência ou interdependência entre variáveis classificadas em categorias (variáveis categóricas).

Tabela 13. Exemplo de proxys para grupos de variáveis investigadas utilizadas na pesquisa de campo: padronização, tamanho e coordenação.

\begin{tabular}{ll}
\hline \multicolumn{1}{c}{ Grupo de variáveis } & \multicolumn{1}{c}{ Categorias } \\
\hline Padronização Percentual de recebimento & 1. Até 20\% \\
de carne desossada embalada em peças. & 2. De 20\% a 60\% \\
(Pergunta 6) & 3. De 60\% a 100\% \\
\hline Tamanho Número de check-outs da loja. & 1. Até 9 \\
& 2. De 10 a 19 \\
& 3. Mais de 20 \\
\hline Coordenacão Prática de preços & 0. Não pratica \\
diferenciados aos fornecedores que & 1. Pratica com um fornecedor \\
entregam a carne pronta para venda. & 2. Pratica com alguns fornecedores \\
(Pergunta 25) & 3. Pratica com todos os fornecedores \\
\hline
\end{tabular}

Fonte: Questionário da pesquisa de campo.

No caso deste trabalho, relembra-se que o que se pretende testar é a 
independência ou interdependência entre três grupos de variáveis: padronização, tamanho e coordenação. Conforme apresentado nos itens anteriores, com base nas informações obtidas sobre as atuais práticas de comercialização de carne bovina in natura em supermercados definiu-se algumas proxys para esses conjuntos de variáveis. Um exemplo dessas proxys pode ser visto na tabela 13.

\subsubsection{Classificação em categorias}

Segundo Everitt (1992), “é possível classificar os membros de uma população um termo genérico representando uma classe bem definida de pessoas ou coisas - de muitas maneiras distintas".(Everitt, 1992, p. 1) As classificações podem ser dicotômicas (apenas duas categorias) ou múltiplas (mais de duas categorias). Todas as proxys utilizadas neste trabalho constituem-se em classificações múltiplas conforme pode ser visto no exemplo da tabela 13.

Quando a população é classificada em várias categorias, torna-se possível contar o número de indivíduos em cada categoria, a freqüência. Esta freqüência é o tipo de informação necessária para a análise de tabelas de contingência ${ }^{20}$. Ao contrário de outras técnicas, que lidam com variáveis contínuas (altura, temperatura, peso, volume e outras) ou quase contínuas (valores monetários), sendo ambas quantitativas, mensuráveis, a análise de tabelas de contingência lida com variáveis qualitativas.

Ao analisar as informações a respeito de uma população classificada é comum ter em mãos somente dados sobre uma amostra dessa população. Dessa forma, trabalha-se na verdade com inferências estatisticamente permitidas, o que é possível também para a análise de tabelas de contingência. Para possibilitar tais inferências, a amostra deve essencialmente ser aleatória, de forma a garantir a sua representatividade em relação à população.

${ }^{20}$ Uma categoria contém ou não um indivíduo, dai o nome da técnica (contingência), cujos 


\subsubsection{Tabelas de contingência}

A tabela de contingência constitui-se na "radiografia" dos dados que se pretende analisar. Em cada uma das células da tabela são representadas as frequêencias de cada uma das categorias.

Cada uma das células $\left(\mathrm{n}_{11}, \mathrm{n}_{12, \ldots,} \mathrm{n}_{\mathrm{rc}}\right.$ ) representa a freqüência, ou seja, a célula $\mathrm{n}_{11}$ representa o número de indivíduos da amostra que estão contidos na categoria 1 da variável 1 e ao mesmo tempo na categoria 1 da variável 2 . A tabela 14 apresenta um exemplo.

Tabela 14. Exemplo de tabela de contingência com múltiplas categorias

\begin{tabular}{|c|c|c|c|c|c|c|}
\hline \multirow{7}{*}{ Linhas (Variável 1) } & & \multicolumn{4}{|c|}{ Colunas (Variável 2) } & \multirow[b]{2}{*}{ Total } \\
\hline & & 1 & 2 & $\ldots$ & $\mathrm{C}$ & \\
\hline & 1 & $\mathbf{n}_{11}$ & $\mathbf{n}_{12}$ & . . & $\mathbf{n}_{1 \mathrm{c}}$ & $\mathbf{n}_{1}$ \\
\hline & 2 & $\mathbf{n}_{21}$ & $\mathbf{n}_{22}$ & .. & $\mathbf{n}_{2 \mathrm{c}}$ & $\mathbf{n}_{2}$ \\
\hline & $\cdot$ & $\begin{array}{l}\cdot \\
\cdot \\
\cdot \\
\end{array}$ & $\begin{array}{l}\cdot \\
. \\
.\end{array}$ & $\cdots$ & $\begin{array}{l}. \\
. \\
.\end{array}$ & $\begin{array}{l}\cdot \\
. \\
.\end{array}$ \\
\hline & $\mathbf{r}$ & $\mathrm{n}_{\mathrm{rl}}$ & & $\ldots$ & $\mathbf{n}_{\mathrm{rc}}$ & $\mathrm{n}_{\mathrm{r}}$ \\
\hline & & n.1 & n.2 & . . & $\mathbf{n}_{\mathbf{c}}$ & n.. $=\mathrm{N}$ \\
\hline
\end{tabular}

Fonte: Bastos (1996).

Estas freqüências podem ser transformadas em proporções ou porcentagens, mas é importante notar que, de qualquer forma que elas estejam apresentadas, os dados eram originalmente frequeências ou contagens em vez de medições de variáveis contínuas. Tais medições de variáveis contínuas podem ser transformadas em medições discretas (freqüências) ao utilizar-se de intervalos com escalas contínuas. 


\subsubsection{Nomenclatura}

A freqüência observada da i-ésima categoria da variável disposta nas linhas e da j-ésima categoria da variável disposta nas colunas, ou seja, a frequência da ij-ésima célula da tabela é representada por $n_{\mathrm{ij}}$. $O$ número total de observações da i-ésima categoria da variável disposta nas linhas é denotado por $\mathbf{n}_{\mathrm{i}}$, enquanto o número total de observações da j-ésima categoria da variável disposta nas colunas é denotado por $\mathbf{n}_{\cdot \mathbf{j}}$. Estes valores são conhecidos como os totais marginais. $O$ número total de observações da amostra é representado por n. ou simplesmente N. Assim:

$$
\begin{aligned}
& \mathrm{n}_{\mathrm{i} .}=\mathrm{n}_{\mathrm{i} 1}+\mathbf{n}_{\mathrm{i} 2}+\mathbf{n}_{\mathrm{i3}}+\ldots+\mathrm{n}_{\mathrm{ic}} \quad(1), \mathrm{e} \\
& \mathbf{n}_{\cdot j}=n_{1 j}+n_{2 j}+n_{3 j}+\ldots+n_{r j} \\
& \text { n.. }=\mathbf{N}=\mathbf{n}_{1 .}+\mathbf{n}_{2 .}+\mathbf{n}_{3 .}+\ldots+\mathbf{n}_{\mathbf{r} .}=\mathbf{n}_{.1}+\mathbf{n}_{.2}+\mathbf{n}_{.3}+\ldots+\mathbf{n}_{. c}
\end{aligned}
$$

\subsubsection{Classificações independentes}

Uma das principais questões a serem respondidas através da análise de tabelas de contingência refere-se à independência entre as variáveis nelas dispostas. Neste trabalho, por exemplo, o objetivo principal é testar a relação de dependência existente entre: (1) adoção de procedimentos padronizados na comercialização de carne bovina e o tamanho da firma; e (2) adoção de procedimentos padronizados na comercialização de carne bovina e a prática de coordenação de fornecedores. Pretende-se aqui esclarecer o conceito de independência.

No caso deste trabalho, se a adoção de procedimentos estáveis e padronizados na comercialização de carne bovina in natura for independente do tamanho da firma, então a proporção de firmas pequenas, médias e grandes que adotam procedimentos estáveis e padronizados não deve diferir significativamente (estatisticamente falando). Se a 
proporção de firmas que adotam procedimentos estáveis e padronizados diferir significativamente (estatisticamente falando) entre as três categorias de tamanho existirá alguma associação entre essas duas variáveis. Estatisticamente falando, duas variáveis serão independentes se as freqüências estimadas não forem significativamente diferentes das frequiências observadas. A freqüência esperada para ij-ésima célula de uma tabela $\left(F_{i j}\right)$ será obtida por:

$$
\begin{aligned}
& \mathrm{F}_{\mathrm{ij}}=\mathrm{N} \cdot \mathrm{p}_{\mathrm{ij}} \\
& \mathrm{N}=\text { número de observações da amostra, } \mathrm{e} \\
& \mathrm{p}_{\mathrm{ij}}=\text { probabilidade de que uma observação da população que será retirada a }
\end{aligned}
$$
amostra pertença à i-ésima categoria da variável disposta nas linhas e à j-ésima categoria da variável disposta nas colunas.

Considerando que $\mathrm{p}_{\mathrm{i}}$. é a probabilidade de que uma observação da população que será retirada a amostra pertença à i-ésima categoria da variável disposta nas linhas e que $\mathrm{p}_{\mathrm{j}}$ é a probabilidade de que uma observação da população que será retirada a amostra pertença à j-ésima categoria da variável disposta nas colunas, então no caso de independência entre duas variáveis tem-se que:

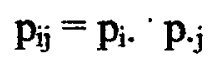

Substituindo (5) em (4), tem-se:

$$
F_{i j}=N \cdot p_{i} \cdot p_{\cdot j}
$$

Para estimar as probabilidades $p_{i .}$ e $p_{\cdot j}$ utiliza-se os seguintes estimadores ${ }^{21}$ :

$$
\begin{aligned}
& \mathbf{p}_{\mathbf{i}}=\mathbf{n}_{\mathrm{i} .} / \mathrm{N} \\
& \mathbf{p}_{\mathrm{j}_{\mathrm{j}}}=\mathbf{n}_{\mathrm{j}} / \mathrm{N}
\end{aligned}
$$

$\mathrm{O}$ uso destes estimadores permite estimar a frequêencia esperada para ij-ésima célula da tabela se as duas variáveis são independentes. Substituindo (7) e (8) em (6) tem-se:

${ }^{21}$ Segundo Mood e Graybill (1963, cap. 12), citado em Everitt (1992, p. 6), estimadores de máxima verossimilhança. 


$$
\begin{aligned}
& E_{i j}=N \cdot p_{i \cdot} \cdot p_{\cdot j} \\
& E_{i j}=N \cdot\left(n_{i \cdot} / N\right) \cdot\left(n_{\cdot j} / N\right), \text { ou } E_{i j}=n_{i \cdot} \cdot n_{\cdot j} / N
\end{aligned}
$$

Assim, se as duas variáveis são independentes então a freqüência esperada estimada $\left(E_{i j}\right)$ em (10) e a freqüência observada $\left(n_{i j}\right)$ não devem ser significativamente diferentes. Conseqüentemente, os testes sobre a independência entre variáveis devem considerar o tamanho da diferença entre as duas frequências, a esperada e a observada.

\subsubsection{Teste Qui-quadrado}

Para o teste sobre a independência entre variáveis Pearson (1904), citado em Everitt (1992), utilizou-se de uma estatística que justamente leva em conta o tamanho da diferença entre as duas freqüências, a esperada e a observada:

$$
\mathrm{X}^{2}=\sum_{i=1}^{r} \sum_{j=1}^{c} \frac{\left(\mathrm{n}_{\mathrm{ij}}-\mathrm{E}_{\mathrm{ij}}\right)^{2}}{\mathrm{E}_{\mathrm{ij}}}
$$

Se as variáveis forem independentes a estatística $\mathrm{X}^{2}$ será menor do que se as variáveis não forem independentes. Assim, como visto em (5) a hipótese nula para o teste de independência deve ser:

Ho: $\quad p_{i j}=p_{i} \cdot p_{\cdot j}$

Neste caso, $\mathrm{X}^{2}$ será menor quando Ho for verdadeira. Deve-se, portanto, identificar qual é o parâmetro para julgar o tamanho da estatística $X^{2} e$, por consequêencia, qual é o parâmetro para levar à aceitação ou não da hipótese de independência. A derivação de uma distribuição de probabilidade para a estatística $\mathrm{X}^{2}$ é o caminho natural. Dada esta distribuição de probabilidade, valores da estatística com pequenas probabilidades levam à rejeição da hipótese nula e, valores da estatística com altas probabilidades levam à aceitação da hipótese nula.

Assumindo que as freqũências observadas têm uma distribuição multinomial e 
que as freqüências esperadas não são muito pequenas, a estatística $X^{2}$ deve mostrar uma distribuição qui-quadrado. Assim, o teste de hipótese constitui-se na comparação do valor calculado para $\mathrm{X}^{2}$ e o valor tabelado da estatística qui-quadrado, com o número de graus de liberdade sendo obtido, segundo Everitt (1992), por:

$$
\gamma=(\mathrm{r}-1) \cdot(\mathrm{c}-1)
$$

(13), onde:

$r=$ número de categorias da variável disposta nas linhas da tabela de contingência;

c = número de categorias da variável disposta nas colunas da tabela de contingência.

\subsubsection{O teste exato de Fisher e a correção de Yates}

A despeito da simplicidade do teste qui-quadrado, Everitt (1992) ressalta que ao considerar-se uma tabela de contingência $\mathbf{r} \times \mathbf{c} 0$ teste de independência entre duas variáveis deve ser feito utilizando-se do chamado teste exato de Fisher, disponível na maioria dos pacotes estatísticos usualmente utilizados. Isto porque nem sempre as hipóteses colocadas para a consideração de variáveis com distribuição de probabilidade de qui-quadrado são factíveis e o teste qui-quadrado poderia, então, falhar na indicação de independência ou associação entre as variáveis. Pino (1998) ressalta ainda que há uma limitação ao teste qui-quadrado:

$$
E_{i j}>1 \text { e } E_{i j}<5 \text {, no máximo em } 20 \% \text { dos casos. }
$$

Assim, em tabelas de contingência nas quais são esperadas freqüências muito pequenas em várias células, o teste qui-quadrado perde o seu poder de defínição sobre a independência dos grupos de variáveis. Contudo, Everitt (1992) comprova que para amostras reduzidas o teste qui-quadrado corrigido pela técnica proposta por Yates (1934), citado em Everitt (1992), proporciona um valor de probabilidade ( $p$ value) similar ao obtido com o teste exato de Fisher. 
Este autor sugere que seja subtraído 0,5 das discrepâncias positivas entre as freqüências esperada e observada e somado 0,5 às discrepâncias negativas, antes que estes valores (discrepâncias) sejam elevados ao quadrado no cálculo da estatística quiquadrado $\left(\mathrm{X}^{2}\right)$. Com esta correção de continuidade, a estatística $\mathrm{X}^{2}$ que antes se apresentava com uma distribuição multinomial (discreta), passa a apresentar uma distribuição contínua.

Tabela 15. Exemplo de tabela de contingência para o caso deste trabalho

\begin{tabular}{|c|c|c|c|c|c|}
\hline & & \multicolumn{4}{|c|}{ Padronização } \\
\hline & & \multicolumn{4}{|c|}{ Recebimento de carne desossada e embalada em peças } \\
\hline & & $0-40 \%$ & $40-60 \%$ & $60-100 \%$ & Total \\
\hline & Pequena & $\mathrm{n}_{11}$ & $\mathbf{n}_{12}$ & $\mathrm{n}_{13}$ & $\mathbf{n}_{1}$ \\
\hline Tamanho da & Pequena/Média & $\mathbf{n}_{21}$ & $\mathbf{n}_{22}$ & $\mathbf{n}_{23}$ & $\mathbf{n}_{2}$ \\
\hline \multirow[t]{4}{*}{ Loja } & Média & $\mathbf{n}_{31}$ & $\mathbf{n}_{32}$ & $\mathbf{n}_{33}$ & $\mathbf{n}_{3}$ \\
\hline & Grande & $\mathbf{n}_{41}$ & $\mathbf{n}_{42}$ & $\mathbf{n}_{43}$ & $\mathbf{n}_{4}$ \\
\hline & Hiper & $\mathbf{n}_{51}$ & $\mathbf{n}_{52}$ & $\mathbf{n}_{53}$ & $\mathbf{n}_{\mathbf{r}}$ \\
\hline & Total & $\mathbf{n}_{.1}$ & $\mathbf{n}_{.2}$ & $\mathrm{n}_{3}$ & $\mathbf{n}_{.}=\mathbf{N}$ \\
\hline
\end{tabular}

Fonte: Elaboração própria a partir de Bastos (1996)

No caso deste trabalho as tabelas de contingência terão o formato apresentado na tabela 15. Nota-se que, com cinco categorias para a variável disposta em linhas, e com três categorias para a variável disposta em colunas, tem-se oito graus de liberdade, conforme (13). Na tabela qui-quadrado tem-se que os valores críticos de $\mathrm{X}^{2}$ são: para $1 \%$ $(20,0902)$ e para $5 \%(15,5073)$.

O teste de hipótese consiste então de comparar-se a estatística calculada e a estatística tabelada. Se a estatística calculada para este trabalho for maior do que a estatística tabelada, então rejeita-se a hipótese nula (hipótese de independência). Neste caso, pode-se aceitar a hipótese de dependência entre as variáveis. 
Este teste deve ser feito para as duas relações pesquisadas. A da hipótese um, que relaciona o tamanho da loja e a padronização na comercialização de carne bovina in natura. A da hipótese dois, que relaciona a padronização e a coordenação de fornecedores. A da hipótese três, que relaciona a coordenação e o tamanho da loja. Se em ambas as relações ocorrer de a estatística calculada ser menor do que a estatística tabelada, ambas as hipóteses seriam rejeitadas, já que todas as hipóteses propunham relações de dependência. 


\section{RESULTADOS}

\subsection{A caracterização da empresa e o conhecimento de novas tecnologias}

A pesquisa revelou uma dicotomia comum nos meios gerenciais. Enquanto é atribuída uma importância considerável ao uso de novas tecnologias de informação (tabela 16), o nível de conhecimento a respeito delas é reduzido (tabela 19), salvo algumas exceções. Tal comportamento comprova a incapacidade administrativa da grande maioria dos empresários supermercadistas (gerentes) no que se refere à adaptação ao uso de novas tecnologias. Existe a demanda pelo conhecimento, mas não há a oferta deste para este nível hierárquico das empresas supermercadistas.

A análise inicia-se por esta observação devido à importância já citada do aspecto cultural e do preparo administrativo para a implantação de ferramentas como o ECR no Brasil. Alguns dos maiores especialistas do assunto concordam que o aspecto cultural é muito mais importante do que o aspecto tecnológico, já que o segundo depende de investimentos na loja e o primeiro de investimentos no funcionário. Assim, acredita-se que do ponto de vista da administração da empresa, o retorno econômico no investimento na loja seja maior do que o do investimento no funcionário.

A tabela 16 mostra o nível de sofisticação das lojas no que se refere ao conjunto mínimo de recursos disponivel. A escolha desses recursos deve-se ao fato de que as publicações setoriais têm dado muita importância a eles como fatores essenciais de diferenciação no atendimento e na redução de custos. Além disso, são recursos físicos indispensáveis para a implantação do ECR nas lojas. 
Tabela 16. Recursos disponíveis na loja (Questão um do questionário)

\begin{tabular}{ccl}
\hline Item & Utilização & \\
\hline C & $58,33 \%$ & Estacionamento para descarga \\
B & $52,78 \%$ & Gerente especifico para grupos de produtos \\
D & $33,33 \%$ & Docas para descarregamento \\
A & $25,00 \%$ & Encarregado de logística \\
F & $22,22 \%$ & Condicionamento de ar nas lojas \\
E & $19,44 \%$ & Empilhadeiras \\
\hline
\end{tabular}

Fonte: Pesquisa de campo.

Alguns recursos têm níveis de utilização mais elevados, como o gerente específico para grupos de produtos, o estacionamento para descarga e, em menor grau, as docas para descarregamento. A presença de gerentes específicos de produtos permite a implantação do Gerenciamento de Categorias, um dos pré-requisitos fundamentais para a implantação do ECR. O estacionamento para descarga e a presença de docas para descarregamento permitem, em conjunto, a implantação da padronização numa de suas etapas: a definição de uma tipologia básica de embalagens e veículos de transporte.

No caso da carne bovina in natura, é praxe entre as lojas a existência de comprador específico para este produto, o que seria um facilitador no caso de implantação do Gerenciamento de Categorias. Além disso, o considerável nível de utilização de recursos como o estacionamento para descarga e as docas de descarregamento facilitariam a chamada "manutenção da cadeia do frio", tão indispensável para produtos pereciveis. Estes recursos facilitariam também a implantação efetiva da paletização também no transporte de carne bovina in natura, o que não é uma prática comum atualmente (tal afirmativa é comprovada no item 4.3 deste trabalho).

Ao realizar-se o teste estatístico para relacionar a utilização destes recursos com o tamanho das lojas não foi conseguido um nível de significância considerável. Contudo, este nível de significância aumenta quando são considerados os recursos menos utilizados, como as empilhadeiras. Isto reflete que, quando considerados os recursos 
menos difundidos, as grandes firmas podem estar mais bem preparadas. Por outro lado, o nível de significância para a relação entre o uso de estacionamento para descarga e o tamanho das lojas também foi maior do que o da maioria dos outros recursos. Isto se dá devido à maior disponibilidade de espaço físico das maiores lojas (lotes maiores).

A tabela 17 mostra a importância atribuída a algumas variáveis competitivas escolhidas. Observa-se, como já esperado para firmas do setor varejista, que o preço de venda e o giro de estoques são as variáveis de maior importância. Em segundo plano, vêm variáveis como o mix de produtos, como esperado também para um supermercado, e o uso de tecnologias de informação. É dessa constatação que surgiu o comentário no início deste item. Existe uma demanda do nível de gerência das lojas para uma maior adaptação às novas tecnologias de informação. Contudo, como veremos na tabela 19, os níveis de conhecimento a respeito destas tecnologias são reduzidos.

Tabela 17. Importância de variáveis competitivas (Questão dois do questionário)

\begin{tabular}{llcccc}
\hline Item & \multicolumn{1}{c}{ Variável } & $\begin{array}{c}\text { Muitto } \\
\text { Importante }\end{array}$ & Importante & $\begin{array}{c}\text { Pouco } \\
\text { importante }\end{array}$ & $\begin{array}{c}\text { Nada } \\
\text { importante }\end{array}$ \\
\hline A & Preço de venda & $\mathbf{6 9 , 4 4 \%}$ & $25,00 \%$ & $2,78 \%$ & $2,78 \%$ \\
D & Giro de estoques & $\mathbf{6 9 , 4 4 \%}$ & $25,00 \%$ & $2,78 \%$ & $2,78 \%$ \\
C & Mix de produtos & $\mathbf{6 1 , 1 1 \%}$ & $30,56 \%$ & $5,56 \%$ & $2,78 \%$ \\
F & Uso de tecnologias de informação & $\mathbf{6 1 , 1 1 \%}$ & $30,56 \%$ & $5,56 \%$ & $2,78 \%$ \\
B & Localização das lojas & $\mathbf{5 0 , 0 0 \%}$ & $44,00 \%$ & $2,78 \%$ & $2,78 \%$ \\
E & Coordenação de fornecedores & $\mathbf{4 0 , 0 0 \%}$ & $54,29 \%$ & $2,86 \%$ & $2,86 \%$ \\
\hline
\end{tabular}

Fonte: Pesquisa de campo.

Ressalta-se também que o nível de gerência das empresas ainda não atribui elevada importância à coordenação de fornecedores como uma variável competitiva importante. Isto ocorre talvez devido ao fato de que, nas pequenas lojas, não há a percepção da importância desta variável e, nas grandes, a coordenação de fornecedores é uma estratégia comandada por níveis hierárquicos superiores.

No que se refere à relação da importância atribuida a estas variáveis e o tamanho das lojas, tem-se que algumas delas têm considerável relação estatística de dependência. 
A tabela 18 mostra tais relações e os níveis de significância estatística.

O mix de produtos não guarda relação estatística de dependência com o tamanho das lojas, o que demonstra a importância universal desta variável. Ressalta-se novamente que a importância do uso de tecnologias de informação é observada na mesma proporção em todos os estratos de tamanho, o que não admite significância estatística para uma relação de dependência entre esta variável e o tamanho da loja.

A importância da localização mostra uma relação direta com o tamanho das lojas. Isto ocorre porque grande parte das maiores lojas da amostra fazem parte de redes de supermercados e, portanto, a localização passa a ter um peso muito grande na competitividade das lojas. Nas lojas menores, geralmente isoladas, a localização é, na maioria das vezes "dada", e não escolhida. Da mesma forma, a importância do giro de estoques apresenta uma considerável relação de dependência com o tamanho das lojas. Isto porque é sabido que as maiores firmas trabalham com margens mais reduzidas e giro mais elevado, ao contrário das menores firmas. A mesma constatação vale para explicar a significância da dependência entre o preço de venda e o tamanho.

Tabela 18. Relação estatística entre a importância de variáveis competitivas e o tamanho das lojas (Questão dois e tamanho).

\begin{tabular}{cclcc}
\hline Item & Importância (a) & $\mathrm{X}_{\text {LOJA }}^{2}(\mathrm{~b})$ & Sign \\
\hline A & $69,44 \%$ & Preço de venda & 17,2629 & $5 \%$ \\
D & $69,44 \%$ & Giro de estoques & 21,7749 & $1 \%$ \\
C & $61,11 \%$ & Mix de produtos & 12,1052 & - \\
F & $61,11 \%$ & Uso de tecnologias de informação & 12,0117 & - \\
B & $50,00 \%$ & Localização das lojas & 18,6192 & $2,5 \%$ \\
E & $40,00 \%$ & Coordenação de fornecedores & 19,0795 & $2,5 \%$ \\
\hline
\end{tabular}

(a) Refere-se à opção "Muita importância".

(b) Com oito graus de liberdade $\left(\mathrm{X}^{2}{ }_{5 \%}=15,51 / \mathrm{X}_{2,5 \%}=17,53 / \mathrm{X}^{2}{ }_{1 \%}=20,09\right)$.

Fonte: Pesquisa de campo.

O nivel de importância atribuída à coordenação de fornecedores tem relação com 
o tamanho das lojas parecida com as duas variáveis acima. Isto reforça o argumento de que nas pequenas lojas não há a percepção da importância desta variável e, nas grandes, a coordenação de fornecedores é uma estratégia comandada por níveis hierárquicos superiores. Esta informação é também um primeiro indício de que existe relação de dependência entre coordenação de fornecedores e tamanho das lojas, como colocado pela hipótese três.

A despeito da grande importância atribuída ao uso de novas tecnologias de informação, observa-se na tabela 19 o baixo nível de conhecimento a respeito destas novas tecnologias. Excetuando-se tecnologias mais difundidas como o código de barras e os terminais de ponto de venda, observa-se níveis de conhecimento inferiores a $42 \%$. Todas as novas tecnologias de informação citadas nesta questão são de fundamental importância para a implantação de estratégias como o ECR, ao serem facilitadoras de troca eletrônica de dados e de regularização do fluxo físico de mercadorias.

Tabela 19. Nível de conhecimento de novas tecnologias (Questão três).

\begin{tabular}{clcccc}
\hline Item & & $\begin{array}{c}\text { Conhece } \\
\text { muito }\end{array}$ & $\begin{array}{c}\text { Conhece } \\
\text { C }\end{array}$ & $\begin{array}{c}\text { Conhece } \\
\text { pouco }\end{array}$ & $\begin{array}{c}\text { Não } \\
\text { conhece }\end{array}$ \\
B & Código de barras & $\mathbf{8 0 , 5 6 \%}$ & $\mathbf{8 , 3 3 \%}$ & $\mathbf{8 , 3 3 \%}$ & $\mathbf{2 , 7 8 \%}$ \\
E & Reposição Contínua & $\mathbf{7 7 , 7 8 \%}$ & $11,11 \%$ & $\mathbf{8 , 3 3 \%}$ & $2,78 \%$ \\
F & Gerenciamento de categorias de produtos & $\mathbf{3 0 , 5 6 \%}$ & $38,89 \%$ & $13,89 \%$ & $16,67 \%$ \\
H & Paletização & $\mathbf{3 0 , 5 6 \%}$ & $27,78 \%$ & $27,78 \%$ & $13,89 \%$ \\
A & EDI & $\mathbf{2 7 , 7 8 \%}$ & $44,44 \%$ & $19,44 \%$ & $\mathbf{8 , 3 3 \%}$ \\
D & Custeio ABC & $\mathbf{2 2 , 2 2 \%}$ & $19,44 \%$ & $33,33 \%$ & $\mathbf{2 5 , 0 0 \%}$ \\
G & Crossdocking & $\mathbf{1 1 , 1 1 \%}$ & $13,89 \%$ & $\mathbf{8 , 3 3 \%}$ & $66,67 \%$ \\
\hline
\end{tabular}

Fonte: Pesquisa de campo.

O baixo nível de conhecimento sobre novas tecnologias de informação reflete a necessidade de investimentos em treinamento para os niveis de gerência das lojas caso a implantação destas tecnologias torne-se freqüente entre os supermercados brasileiros. Esta afirmativa refere-se ao setor como um todo, já que grandes redes tendem a 
apresentar níveis de preparação maiores de seus gerentes.

Nenhuma das novas tecnologias citadas tem o nível de conhecimento relacionado ao tamanho da loja, exceto a de códigos de barras, o que pode ser comprovado estatisticamente e visto na tabela 20. Assim, a amostra considerada não permite afirmar que o conhecimento a respeito de novas tecnologias está mais difundido entre as grandes lojas, e menos difundido entre as menores. Isto comprova que há lojas de grandes redes que não apresentam grande preocupação com a questão da adaptação às estratégias recentes, como o ECR. Por outro lado, as tecnologias com maior nível de conhecimento são as que mais se aproximam de uma significância estatística no que se refere à dependência em relação ao tamanho da firma.

Tabela 20. Relação estatística entre o nível de conhecimento de novas tecnologias e o tamanho da firma (Questão três e tamanho).

\begin{tabular}{crlcc}
\hline Item & Conhecimento (a) & X $_{\text {FRMA (b) }}$ & Sign \\
\hline C & $\mathbf{8 0 , 5 6 \%}$ & PDV - Terminal de Ponto de Venda & 11,5320 & - \\
B & $\mathbf{7 7 , 7 8 \%}$ & Código de barras & 16,8245 & $5 \%$ \\
E & $\mathbf{4 1 , 6 7 \%}$ & Reposição Contínua & 2,6371 & - \\
F & $\mathbf{3 0 , 5 6 \%}$ & Gerenciamento de categorias & 9,6449 & - \\
H & $\mathbf{3 0 , 5 6 \%}$ & Paletização & 1,8890 & - \\
A & $\mathbf{2 7 , 7 8 \%}$ & EDI & 7,5901 & - \\
D & $\mathbf{2 2 , 2 2} \%$ & Custeio ABC & 0,9504 & - \\
G & $\mathbf{1 1 , 1 1 \%}$ & Crossdocking & 3,8948 & - \\
\hline
\end{tabular}

(a) Refere-se à opção "Conhece muito".

(b) Com oito graus de liberdade $\left(X^{2}{ }_{5 \%}=15,51\right)$.

Fonte: Pesquisa de campo.

Foi pesquisado ainda o nível de conhecimento dos gerentes de lojas a respeito do Programa ECR Brasil, citado no item 2.2 deste trabalho, responsável pela difusão dessa estratégia no setor supermercadista brasileiro. Cerca de $54 \%$ dos entrevistados afirmaram conhecer pouco ou nada sobre o Programa, e apenas $6 \%$ afirmaram conhecê- 
lo muito (Questão 4). Assim, comprova-se a necessidade de treinamento deste nível hierárquico, se for do interesse do Programa difundir o ECR por todo o setor, e não apenas para as grandes. $O$ baixo conhecimento a respeito do Programa ECR Brasil relaciona-se diretamente ao baixo nível de conhecimento das novas tecnologias de informação, mostrado na tabela 18.

A tal desconhecimento pode ser atribuída uma grande importância, já que as regiões alvo da pesquisa supostamente estão dentro da área de maior influência da ABRAS e, conseqüentemente, do Programa ECR Brasil.

\subsection{A padronização na comercialização de carne bovina in natura.}

A figura 2 mostra a fronteira tecnológica no recebimento de carne bovina in natura pelos supermercados da amostra. Tomando como base o nivel de utilização das proxys de padronização no recebimento consideradas na pesquisa (as variáveis pesquisadas nas questões de cinco a nove), define-se a fronteira tecnológica limite como sendo a variável da questão nove: recebimento de carne desossada e embalada em cortes prontos, paletizada.

Percebe-se na figura que o nível de utilização desta proxy é bastante reduzido, já que mais de $90 \%$ das lojas entrevistadas afirmaram que recebem menos de $20 \%$ da carne bovina desta forma. Assim, como definido no objetivo do trabalho, cabe a definição da fronteira tecnológica possível, ou seja, qual é, dentre as proxys escolhidas, aquela que apresenta o maior nível de utilização.

Temos duas fronteiras tecnológicas possíveis segundo a figura 1. A primeira é o recebimento de carne desossada embalada, já que cerca de $80 \%$ das lojas entrevistadas afirmaram receber menos de $20 \%$ da carne desossada sem embalagem (questão 5). $\mathrm{O}$ recebimento de carne desossada e embalada em peças (questão seis) constitui-se no que refere-se ser a segunda fronteira tecnológica possível na padronização do recebimento de carne bovina in natura por supermercados. Cerca de $60 \%$ das lojas entrevistadas 
afirmaram receber mais de $60 \%$ da carne dessa maneira.

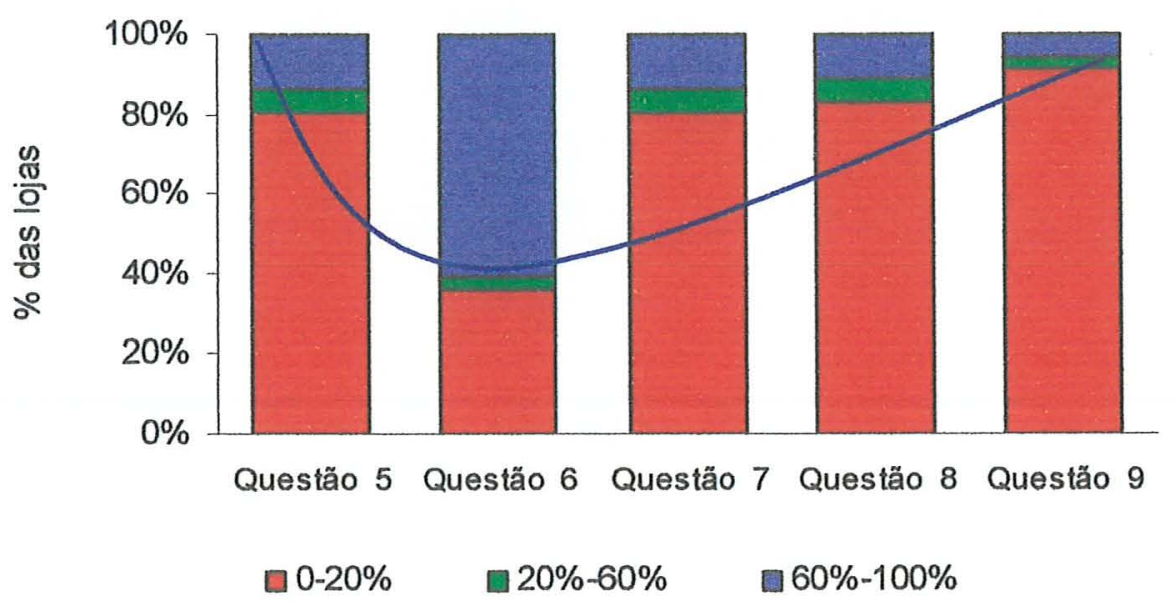

Questão 5 Percentual aproximado de recebimento de carne desossada sem embalagem.

Questão 6 Percentual aproximado de recebimento de carne desossada embalada em peças.

Questão 7 Percentual aproximado de recebimento de carne desossada embalada em cortes prontos.

Questão 8 Percentual aproximado de recebimento de carne desossada embalada em cortes prontos com marca do fornecedor.

Questão 9 Percentual aproximado de recebimento de carne desossada embalada em cortes prontos paletizada.

Figura 2. Níveis de utilização das proxys escolhidas para representar as práticas de padronização no recebimento de carne bovina in natura pela loja de supermercado.

No que se refere à venda da carne bovina in natura, a fronteira tecnológica limite é a proxy da questão 12, já que foi a prática de venda de carne embalada e com marca do fornecedor aquela que obteve o menor nível de utilização. Cerca de $80 \%$ das lojas afirmaram vender menos de $20 \%$ da carne comercializada desta maneira.

Assim como no caso do recebimento da carne bovina in natura, a padronização na venda necessitou da determinação de uma fronteira tecnológica possível, ou seja, 
quais seriam as proxys, que representam práticas de padronização, que mais são utilizadas pelos supermercados da amostra. Percebe-se na figura 3 que o nível de utilização da proxy carne embalada em cortes prontos (boxed beefs), na questão 10, é a fronteira tecnológica possível para a padronização na venda da carne bovina in natura.

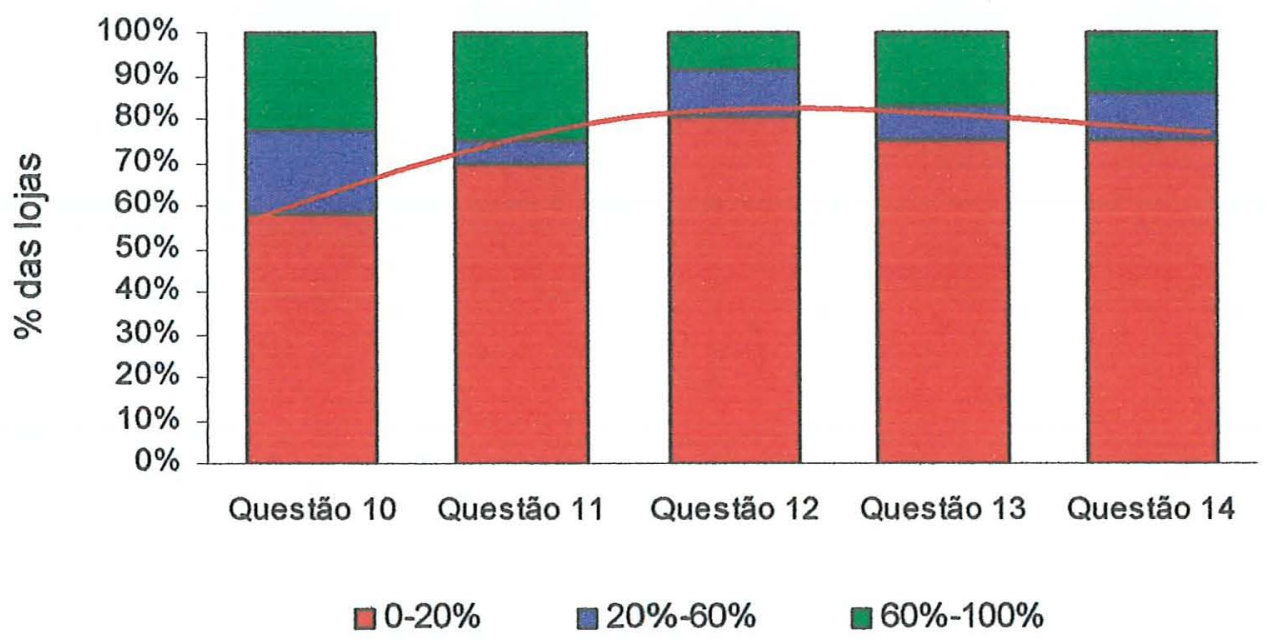

Questão 10 Percentual aproximado de venda de carne embalada em cortes prontos.

Questão 11 Percentual aproximado de venda de carne embalada com código de barras.

Questão 12 Percentual aproximado de venda de carne embalada com marca do fornecedor.

Questão 13 Percentual aproximado de venda de carne embalada com marca do supermercado.

Questão 14 Percentual aproximado de venda de carne embalada com etiqueta de identificação completa.

Figura 3. Níveis de utilização das proxys escolhidas para representar as práticas de padronização na venda de carne bovina in natura pela loja de supermercado.

Como uma segunda fronteira tecnológica possível tem-se a venda de carne embalada e com código de barras (questão 11). Cerca de 30\% das firmas entrevistadas afirmaram vender mais de $60 \%$ da carne bovina in natura desta forma. Ressalta-se, contudo, que mesmo para uma fronteira possível o nível de utilização é 
consideravelmente reduzido.

\subsection{Características do hábito de compra de carne bovina}

Neste tópico são apresentadas algumas das características pesquisadas do hábito de compra de carne bovina in natura dos supermercados da amostra. Os resultados aqui apresentados visam enriquecer a conclusão do trabalho a respeito das relações existentes entre a padronização, a coordenação e o tamanho das lojas.

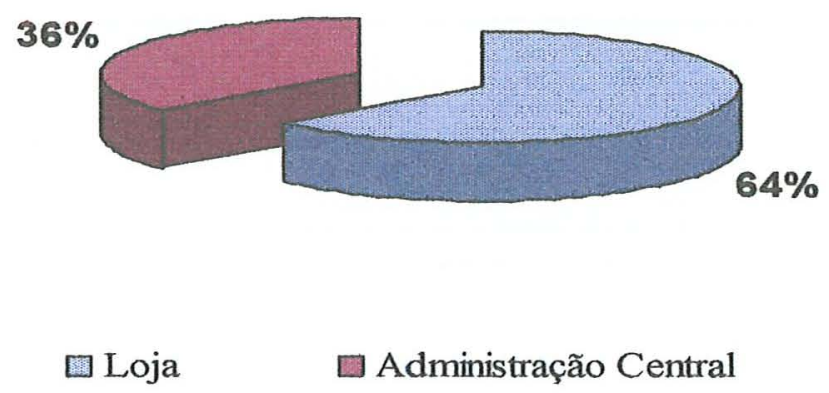

Figura 4. Responsável direto pela reposição de carne bovina in natura (Questão 15).

Uma primeira característica refere-se ao responsável pela compra de carne bovina in natura, mostrada na figura 4 . Os resultados mostram que $64 \%$ das lojas entrevistadas são as próprias responsáveis pelo abastecimento de carne e 36\% afirmaram que a administração central desempenha esta atividade. Tal fato pode ser explicado pelo grande peso na pesquisa das pequenas firmas, que geralmente possuem apenas uma loja, e de grandes firmas, cujas lojas entrevistadas possuem autonomia em certas áreas.

Este resultado tem uma relação importante com o ECR e a padronização. Como as lojas têm uma considerável autonomia na compra de carne bovina in natura, o efetivo controle de vendas através de técnicas como o scanning (ver anexo 3) nas lojas, pode 
proporcionar para a cadeia de suprimento informações confiáveis do fluxo físico da carne. Ao mesmo tempo, se esta informação for compartilhada com o fornecedor, via computador ou não, pode-se imaginar o potencial de regularização da oferta, loja a loja e, conseqüentemente, por todo o setor supermercadista. Um exemplo é o controle direto de quais partes do traseiro e do dianteiro são mais vendidas em cada loja, o que permitiria ao fornecedor, em conjunto com os supermercados, distribuir o produto de acordo com a efetiva demanda.

Foi verificada também a forma na qual é feito o contato entre supermercado e fornecedor. $\mathrm{O}$ resultado pode ser visto na figura 5 . O contato telefônico ainda é a forma mais utilizada, tanto para frigoríficos quanto para atacadistas. Uma pequena parcela utiliza o contato via computador com o frigorífico e, mesmo assim, não se sabe ao certo se através de algoritmo de controle de estoques. Portanto, devido talvez à fragilidade dos contratos utilizados na relação supermercado/frigorífico, o contato telefônico ainda atua como principal meio de comunicação nos negócios.

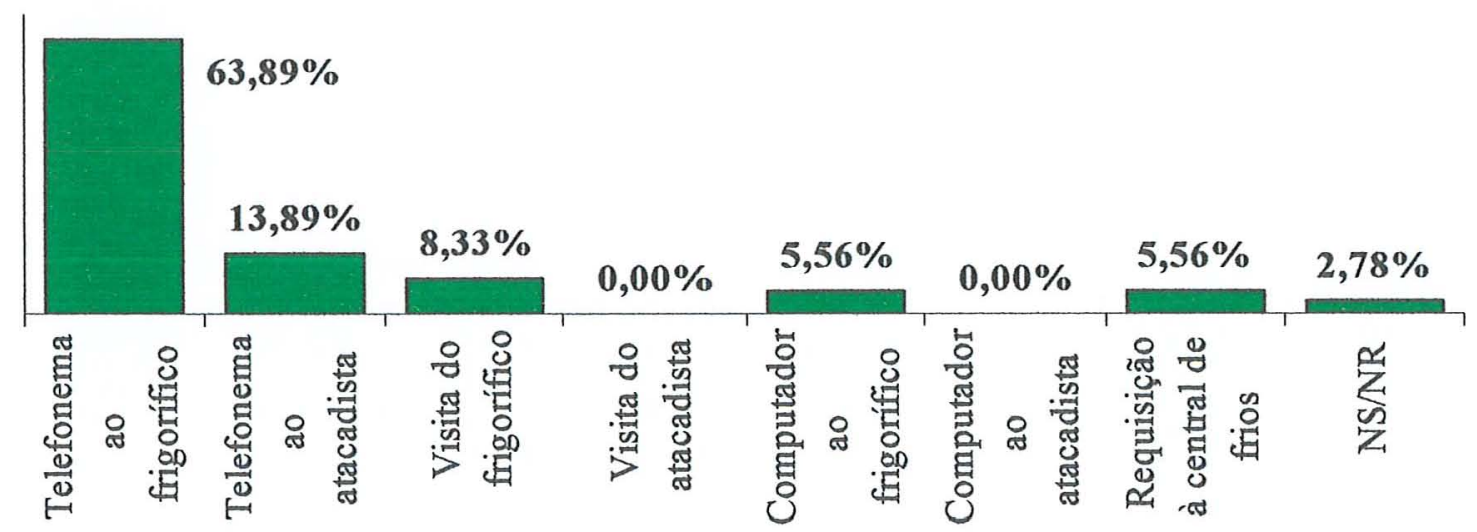

Figura 5. Tipos usuais de contatos para a reposição de carne in natura (Questão 16).

Fonte: Pesquisa de campo.

Uma variável importante para se conhecer os hábitos de compra de carne bovina in natura é a freqüência com que se trata a reposição desse produto nas lojas. Os resultados mostram uma opção pela compra mais freqüente, diária, semanal ou até 
mesmo automática (just in time). Assim, nesse tipo de transação, mesmo que haja elementos contratuais presentes, a relação comercial tem uma frequência bastante recorrente. A figura 6 mostra os resultados.

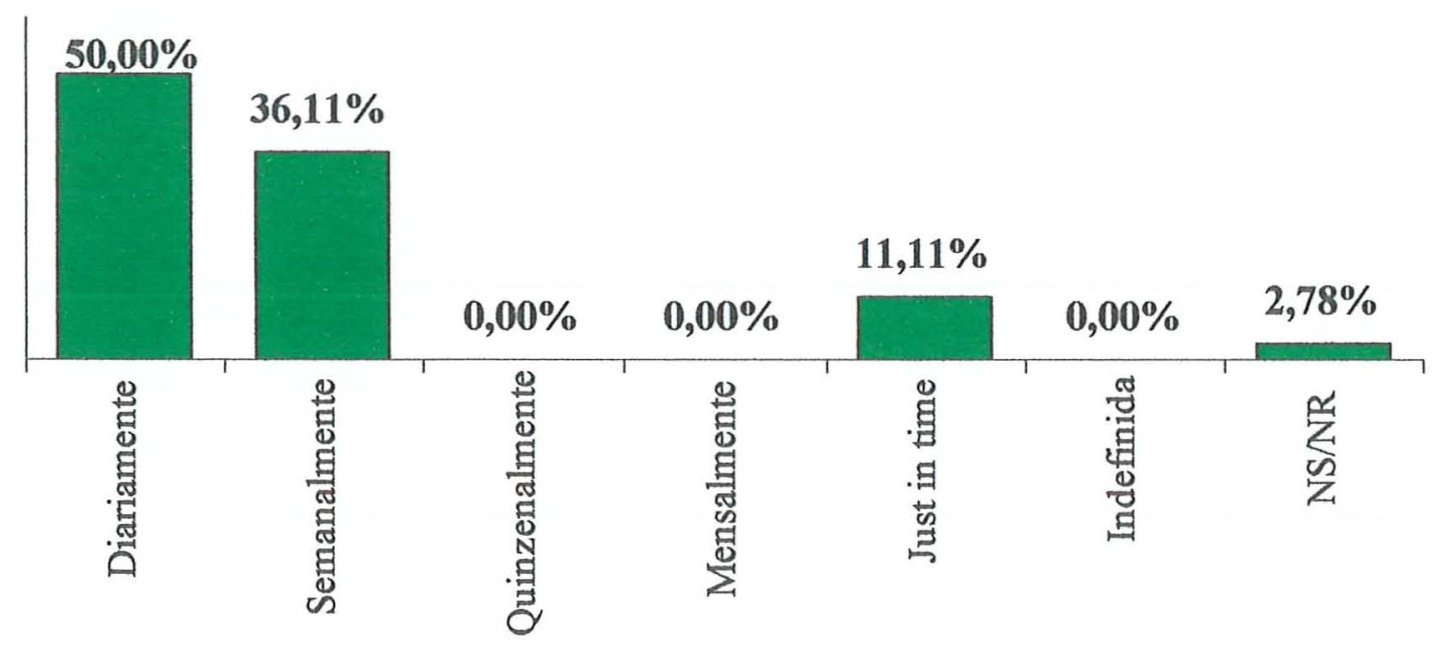

Figura 6. Freqüência de compra de carne bovina in natura (Questão 17).

Fonte: Pesquisa de campo.

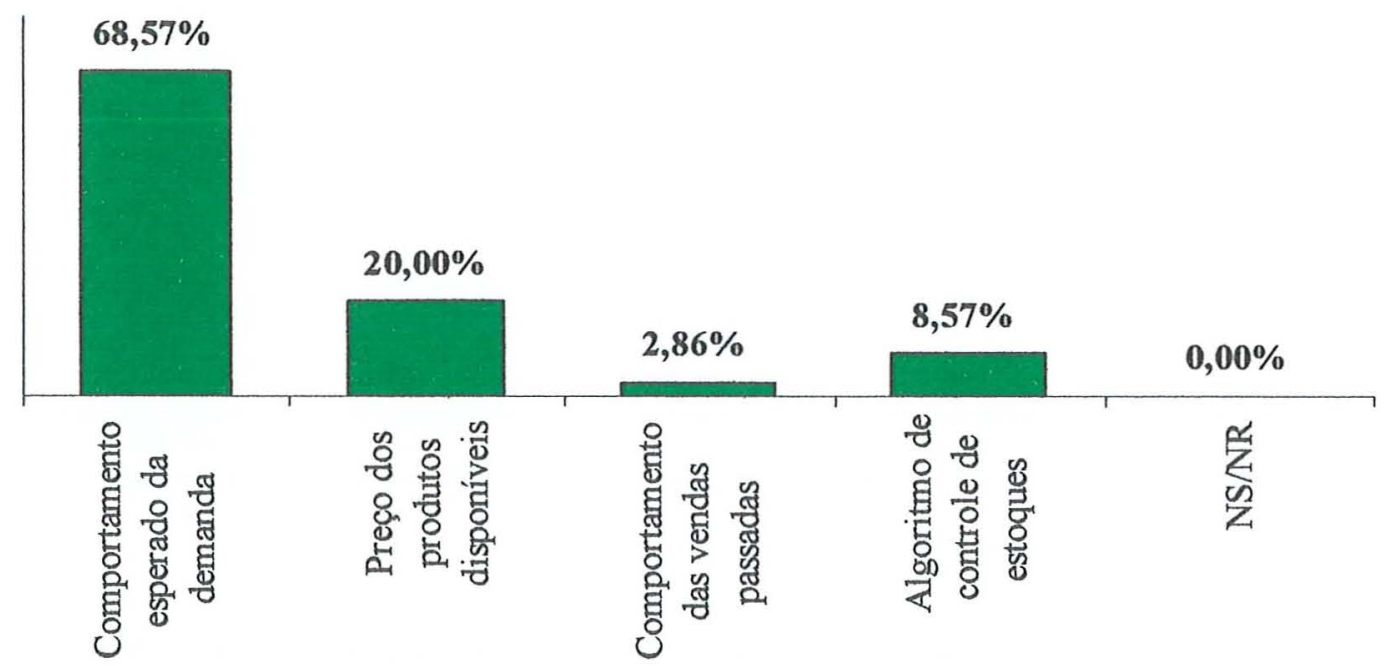

Figura 7. Fatores decisivos para a decisão do volume de carne comprada (Questão 18). Fonte: Pesquisa de campo. 
A pesquisa abordou também quais seriam os fatores decisivos para decidir o quanto comprar de carne bovina in natura. O objetivo desta questão foi o de identificar o nível de importância de opções como o uso de algoritmos de controle de estoques, o que seria o ideal do ponto de vista da gestão de cadeias de suprimento e do ECR. No entanto, vê-se na figura 7 que o nível de utilização deste tipo de instrumento para controlar o volume de compras ainda é baixo. O comportamento esperado da demanda (feeling) e o preço dos produtos ainda são os maiores orientadores do volume de compras.

Os preços e a qualidade da carne são os principais fatores (figura 8) para a decisão do supermercado sobre o fornecedor a ser escolhido. Tal fato relaciona-se negativamente com as estratégias de gestão de cadeias de suprimento, já que tais estratégias prevêm uma maior regularidade no fluxo de mercadorias, criando mecanismos de diminuição da importância das oscilações de preços e da variação da qualidade.

Contudo, não espera-se que preços e qualidade deixem de ser as principais variáveis de definição de compra, mas sim, que fatores como o cumprimento da entrega programada ganhem importância, ainda reduzida segundo o resultado desta pesquisa.

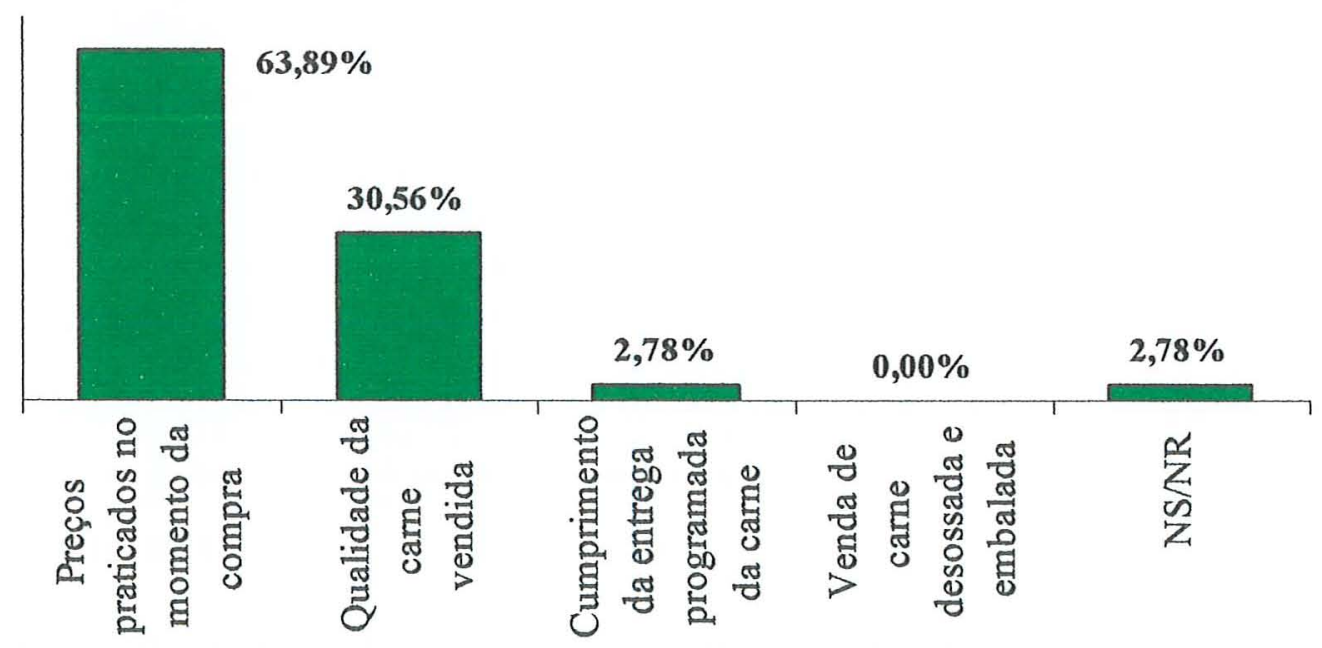

Figura 8. Fatores decisivos para a decisão de escolha do fornecedor (Questão 19). Fonte: Pesquisa de campo. 
Os supermercados entrevistados não mantêm uma pulverização considerável de fornecedores de carne, conforme pode ser visto na figura 9. Observa-se que mais de $70 \%$ das lojas entrevistadas mantêm até quatro fornecedores. A pesquisa revelou que os três principais fornecedores são o Frigorífico Bertin, o Frigorífico Friboi e o FrigoAlta.

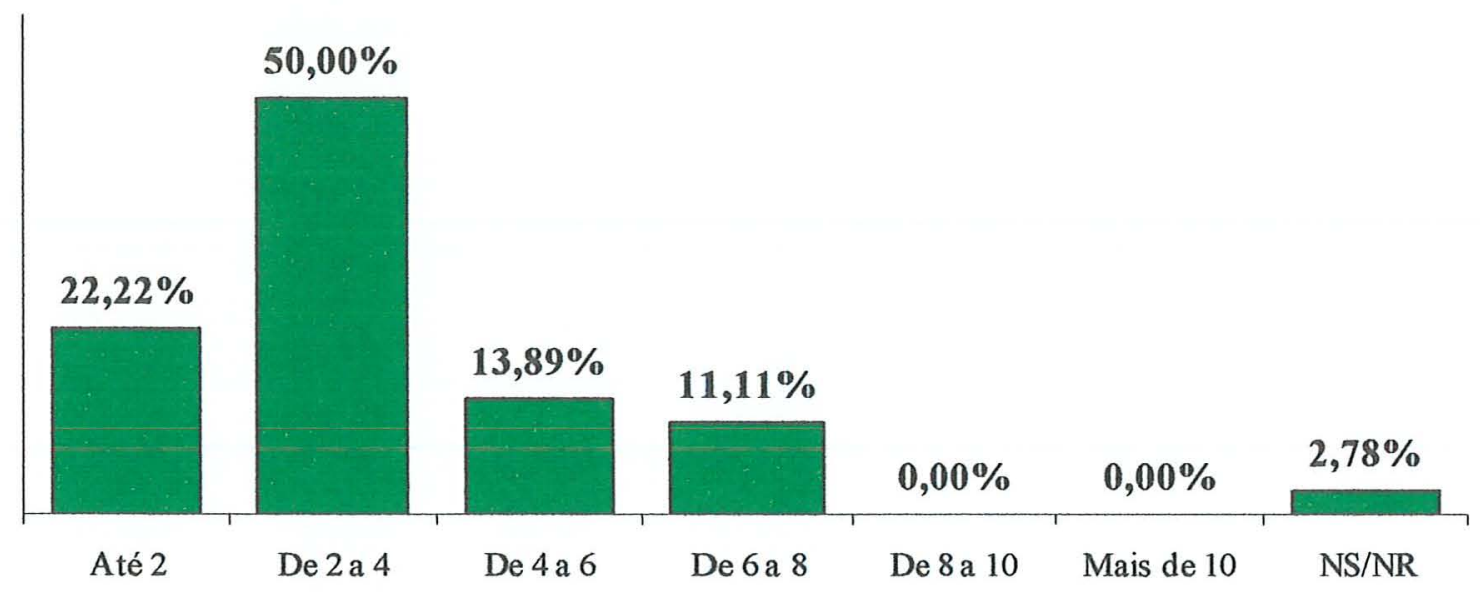

Figura 9. Número de fornecedores de carne bovina in natura (Questão 20). Fonte: Pesquisa de campo.

Quanto à demanda dos supermercados por melhorias em seus fornecedores, citase uma considerável necessidade por racionalização do processo de entrega da carne nas lojas. Observa-se a grande importância atribuída à manutenção da escala de entregas programada e à diminuição do tempo decorrente entre o pedido e a entrega. Tal necessidade relaciona-se diretamente às estratégias estudadas neste trabalho.

A gestão de cadeias de suprimento e o ECR visam justamente atuar sobre estes problemas, e a padronização, um dos pré-requisitos para tais estratégias, é a ferramenta que atua diretamente sobre os problemas de transporte e entrega do produto. A figura 10 mostra as demandas das lojas entrevistadas. Percebe-se também a já esperada importância atribuída às condições de pagamento e preços praticados pelos fornecedores. 


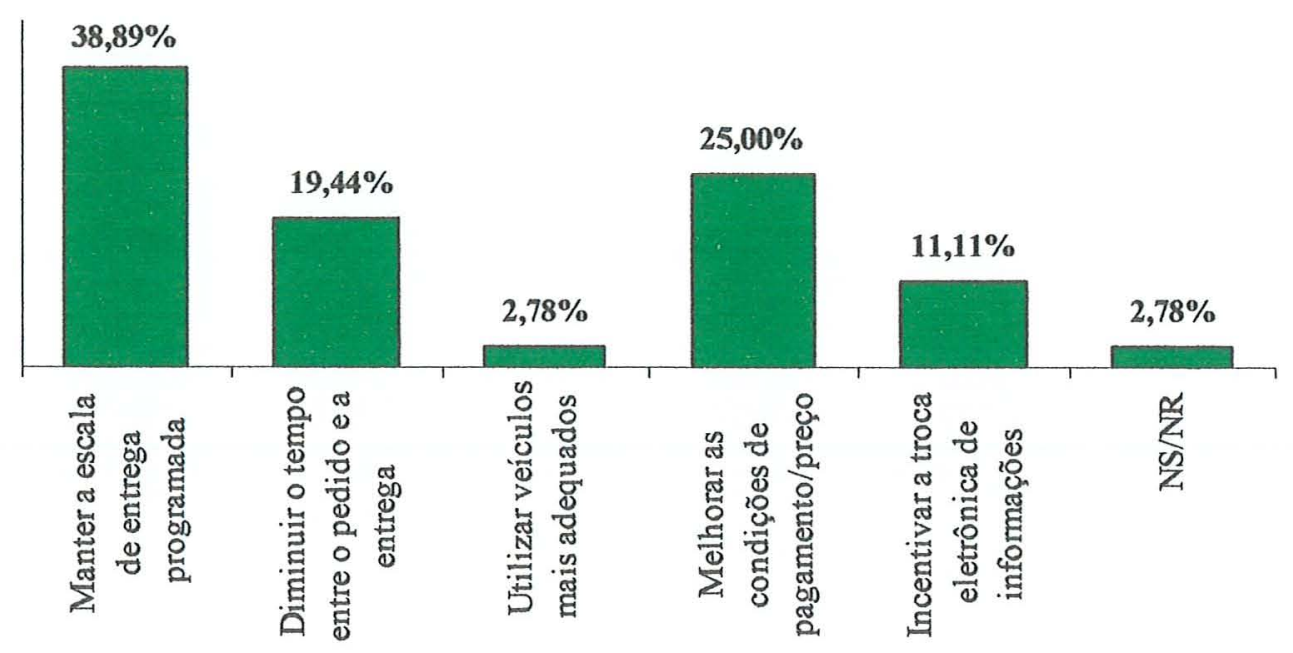

Figura 10. Ações redutoras de custos na reposição de estoques (Questão 21).

Fonte: Pesquisa de campo.

De forma a obter uma possível relação entre o tamanho da loja e o volume de carne comprada por semana apresenta-se a figura 11. Nela estão mostrados como se distribuem os volumes médios aproximados de carne bovina comprada pela loja por semana por estrato de tamanho de loja. Visualmente observa-se que à medida que aumenta o volume de carne comprada, aumenta também a participação das lojas maiores nesse volume, ou seja, estabelece-se uma relação de dependência entre tamanho da loja e volume de carne comprada, conforme esperado.

Além da constatação visual desta relação, obtém-se a comprovação estatística. Com vinte graus de liberdade (com seis categorias de volume e cinco categorias de tamanho) tem-se que a estatística qui-quadrado tabelada ao nível de $5 \%$ vale 31,41 . A estatística calculada para a tabela de contingência de volume de carne comprada e tamanho da loja vale 32,91. Desta forma, aceita-se a hipótese de que existe relação de dependência entre o volume de carne comprada e o tamanho da loja de supermercado considerada. 


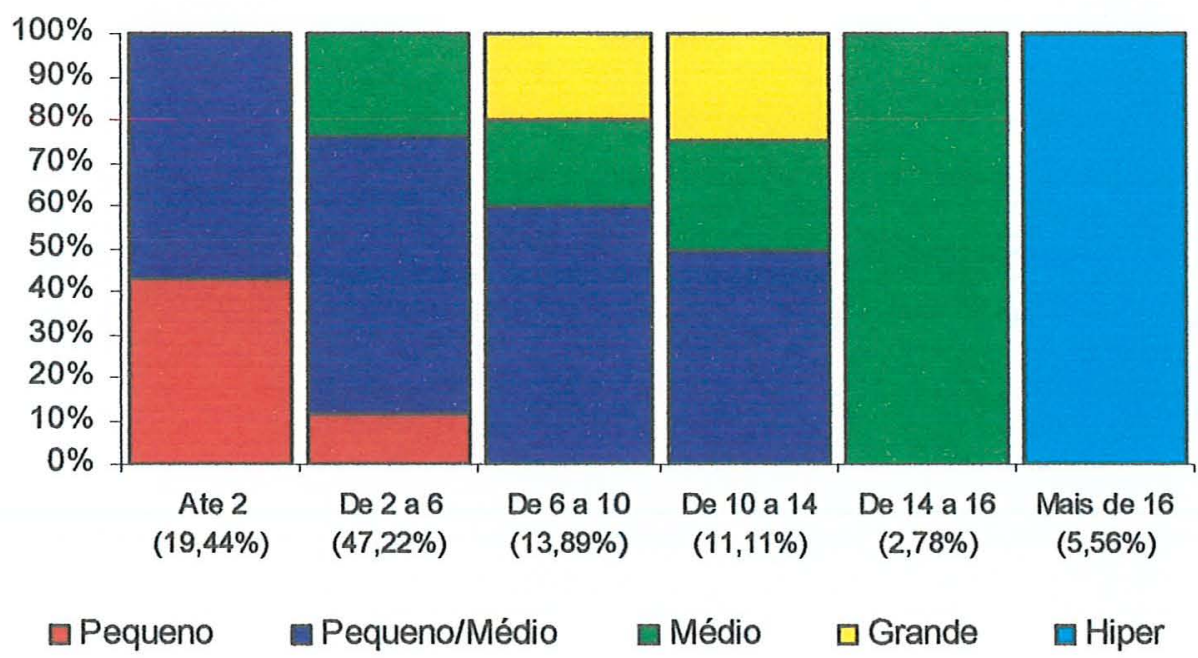

Figura 11. Volume médio aproximado de carne bovina comprada por semana pela loja por estrato de tamanho (Questão 32).

Fonte: Pesquisa de campo.

\subsection{A coordenação de fornecedores na comercialização de carne bovina in natura.}

A figura 12 mostra a fronteira tecnológica na coordenação de fornecedores de carne bovina in natura pelos supermercados da amostra. Tomando como base o nível de utilização das proxys de coordenação de fornecedores consideradas na pesquisa (as variáveis pesquisadas nas questões de 22 a 30), define-se a fronteira tecnológica limite como sendo as variáveis das questões 24 (preços diferenciados aos fornecedores que entregam a carne pronta para a venda), 26 (preferência na descarga aos fornecedores que entregam a carne paletizada), 28 (contrato de fornecimento constando o preço), 29 (contrato de fornecimento constando o preço e a freqüência de entrega) e 30 (contrato de fornecimento constando o preço, a freqüência de entrega e exigências sobre a qualidade da carne).

Em todos os casos mais de 70\% das firmas afirmaram não praticar tal mecanismo de coordenação de fornecedores. As questões 22 a 27 referem-se a mecanismos de 
incentivo e as questões 28 a 30 referem-se a mecanismos de controle, sendo que ambos (incentivo e controle) fazem parte de um esquema de coordenação, segundo a literatura pertinente.

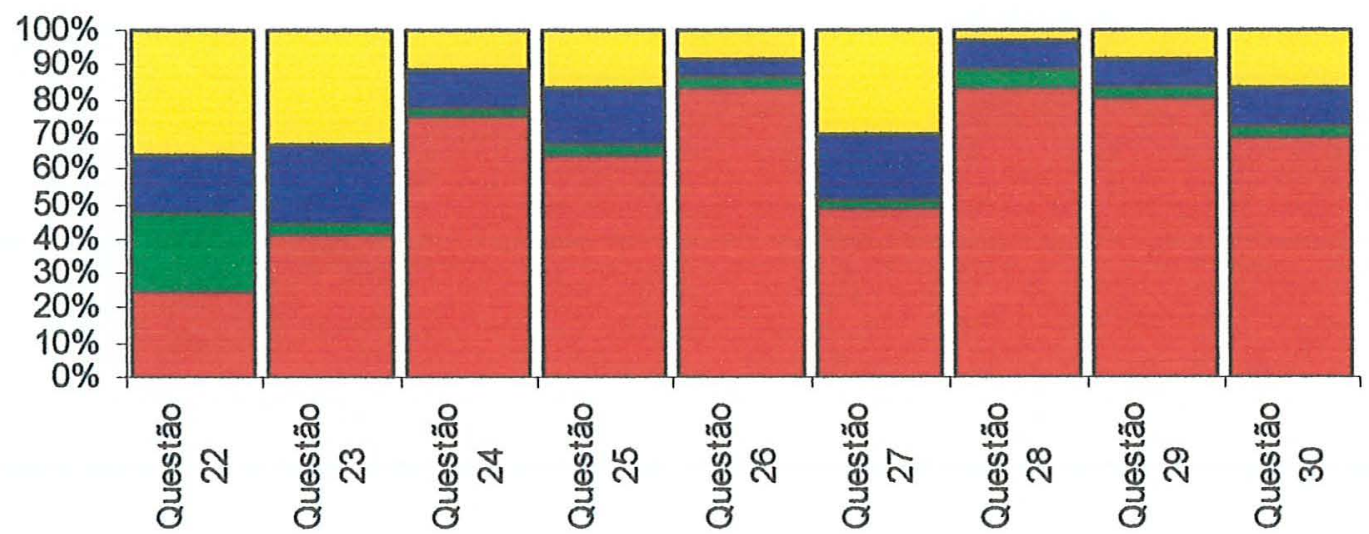

$\square$ Não pratica $\quad$ Pratica fracamente Pratica moderadamente $\quad$ Pratica muito

Questão 22 Preferência na descarga aos fornecedores que entregam a carne em horário programado.

Questão 23 Preços diferenciados aos fornecedores que entregam a carne desossada.

Questão 24 Preços diferenciados aos fornecedores que entregam a carne pronta para a venda.

Questão 25 Preços diferenciados aos fornecedores que entregam a carne embalada.

Questão 26 Preferência na descarga aos fornecedores que entregam a carne paletizada.

Questão 27 Preços diferenciados aos fornecedores que identificam a origem da carne.

Questão 28 Contrato de fornecimento constando somente o preço.

Questão 29 Contrato de fornecimento constando o preço e a freqüência de entrega.

Questão 30 Contrato de fornecimento constando o preço, a freqüência de entrega e exigências sobre a qualidade da carne.

Figura 12. Níveis de utilização das proxys escolhidas para representar as práticas de coordenação de fornecedores de carne bovina in natura pela loja de supermercado.

Fonte: Pesquisa de campo.

A fronteira tecnológica possível restringe-se ainda às proxys das questões 22 (preferência na descarga aos fornecedores que entregam a carne em horário programado) e 23 (preços diferenciados aos fornecedores que entregam a carne desossada). Tal 
constatação baseia-se no fato de que menos de $40 \%$ dos entrevistados afirmaram não praticar tal mecanismo de coordenação e mais de $40 \%$ afirmaram praticar muito (com todos os fornecedores). 


\section{ANÁLISE DOS DADOS}

Neste capítulo são realizados os testes de hipótese do trabalho e, com base nas informações obtidas na revisão bibliográfica e na pesquisa de campo, conforme apresentado nos capítulos anteriores, são analisadas as informações geradas.

\subsection{Teste da hipótese um}

A hipótese um revisitada:

1) a distância de uma loja da fronteira tecnológica da padronização na comercialização de carne bovina in natura é inversamente relacionada ao tamanho da loja. Assim, espera-se que as maiores lojas estejam mais próximas de uma fronteira tecnológica hipotética de padronização.

O teste estatístico realizado na amostra da pesquisa não permite aceitar a hipótese um, conforme os valores das estatísticas calculadas e tabeladas mostrados na tabela 21 . Para testar a hipótese um também em relação ao tamanho da firma (Razão Social), separamos a população e a amostra proporcional em grandes (faturamento anual em 1998 superior a R\$ 300 milhões), médias (faturamento anual em 1998 superior a R\$100 milhões e inferior a R\$300 milhões) e pequenas (faturamento anual em 1998 inferior a R\$ 100 milhões), segundo o critério da ABRAS. Na tabela 21, $\mathrm{X}^{2}{ }_{\text {LOJA }}$ identifica a estatística calculada para o tamanho da loja e $\mathrm{X}^{2}$ FRMA a mesma estatística para o tamanho da firma. 
Tabela 21. Teste para avaliação da dependência entre proxys de padronização na comercialização de came bovina in natura em supermercados e tamanho da loja e da firma.

\begin{tabular}{|c|c|c|c|c|c|}
\hline & Questão & Nível de utilização (a) & $\mathrm{X}_{\text {LOJA }}^{2}(\mathrm{~b})$ & $\mathrm{X}_{\text {FIRMA }}^{2}(\mathrm{c})$ & Sign \\
\hline \multirow[t]{5}{*}{ Recebimento } & (5) & $80,56 \%$ & 3,8756 & 1,9850 & - \\
\hline & $(6)$ & $36,11 \%$ & 10,8936 & 6,6946 & $25 \%$ \\
\hline & (7) & $80,56 \%$ & 4,0185 & 1,9712 & - \\
\hline & (8) & $83,33 \%$ & 4,1825 & 2,1003 & - \\
\hline & (9) & $91,67 \%$ & 11,8588 & 6,8432 & $25 \%$ \\
\hline \multirow[t]{5}{*}{ Venda } & $(10)$ & $58,33 \%$ & 1,8302 & 0,4384 & - \\
\hline & $(11)$ & $69,44 \%$ & 7,7061 & 2,0170 & - \\
\hline & $(12)$ & $80,56 \%$ & 3,4674 & 1,1487 & - \\
\hline & $(13)$ & $75,00 \%$ & 6,8274 & 1,0083 & - \\
\hline & (14) & $75,00 \%$ & 7,5892 & 2,3803 & - \\
\hline
\end{tabular}

(a) Refere-se a "Recebe/Vende menos de $20 \%$ da carne desta forma".

(b) Graus de liberdade: $8 \cdot X^{2}{ }_{5 \%}=15,51$.

(c) Graus de liberdade: $4 . X^{2}{ }_{5 \%}=9,488$.

(5) Recebimento de carne desossada sem embalagem.

(6) Recebimento de carne desossada embalada em peças.

(7) Recebimento de carne desossada embalada em cortes prontos.

( 8 ) Recebimento de carne desossada embalada com marca do fornecedor.

(9) Recebimento de carne desossada embalada em cortes prontos paletizada.

(10) Venda de carne embalada em cortes prontos.

(11) Venda de carne embalada com código de barras.

(12) Venda de carne embalada com marca do fornecedor.

(13) Venda de carne embalada com marca do supermercado.

(14) Venda de carne embalada com etiqueta de identificação completa sobre o produto.

Fonte: Pesquisa de campo.

No recebimento da carne bovina pela loja, observa-se que há algumas proxys com elevado nível de utilização (fronteira tecnológica possível). $O$ recebimento de carne desossada e sem embalagem, considerado neste trabalho a prática mais ultrapassada do ponto de vista da padronização é utilizada por cerca de $14 \%$ das lojas da amostra, o que mostra um avanço no sentido de uma maior preocupação com o transporte da carne e, por outro lado, a pressão exercida pelas portarias editadas pelo governo que exigem o registro no Ministério da Agricultura (SIF) para a realização da desossa na própria loja. A generalização para todos os tamanhos de loja e firmas pode ser observada através da significância nula do teste de dependência entre esta prática de 
recebimento de carne bovina in natura e o tamanho da loja e da firma.

O recebimento de carne desossada e embalada em peças constitui-se no que refere-se ser a atual fronteira tecnológica possivel no recebimento de carne bovina in natura pelas lojas, segundo a amostra estudada. Tal afirmação baseia-se no considerável nível de utilização desta prática (apenas $36,11 \%$ das firmas da amostra afirmaram receber menos de $20 \%$ da carne desta forma). A despeito da baixa significância estatística na relação de dependência entre esta prática e o tamanho tanto da loja quanto o da firma, observa-se que neste caso o nivel de significância aumenta significativamente.

Tal fato, apesar de não permitir afirmar que exista uma relação de dependência entre o recebimento de carne desossada e embalada em peças e tamanho (loja e firma), levanta a necessidade de uma ampliação da amostra, para verificar se numa pesquisa quase censitária este nível de significância atinge patamares consideráveis. A amostra utilizada, apesar de proporcional tanto no que se refere ao tamanho da loja quanto ao tamanho da firma, pode estar falhando para identificar tal associação entre as variáveis.

No momento prefere-se aceitar que a hipótese um não pôde ser comprovada. $O$ fato de trabalhar-se com a fronteira tecnológica possível pode estar inviabilizando a relação de dependência entre a padronização e o tamanho, seja da loja ou da firma, já que esta seria uma prática difundida e que, portanto, estaria acessivel a todos os estratos de tamanho.

Por outro lado, o recebimento de carne desossada embalada em cortes prontos e paletizada (o caso das boxed beefs e consumer units citados no item 2.3 deste trabalho) constitui-se no que refere-se ser a fronteira tecnológica limite no recebimento de carne bovina in natura pelas lojas, já que $91,67 \%$ dos entrevistados afirmaram receber menos de $20 \%$ da carne desta forma. Para o caso deste trabalho, esta prática é considerada o limite da padronização na comercialização de carne bovina in natura pelos supermercados.

Observa-se que, como uma prática limite, o nível de significância volta a 
apresentar uma tendência de elevação (tal afirmação baseia-se no aumento dos valores da estatística $X^{2}$ calculada), mostrando uma possível relação de dependência entre $o$ recebimento de carne desossada embalada em cortes prontos e paletizada e o tamanho da loja. As outras formas de recebimento pesquisadas alcançaram niveis de utilização reduzidos e niveis de significância também reduzidos. Tal fato revela que estas outras práticas são pouco utilizadas por todos os estratos de tamanho de lojas e firmas.

No que se refere à venda da carne bovina in natura, as lojas da amostra se mostraram pouco preparadas quanto à padronização. A venda de carne embalada em cortes prontos e a venda de carne embalada em cortes prontos com código de barras são as práticas mais comuns. Ambas mostram-se práticas difundidas por todos os estratos de tamanhos, já que o nível de significância para a relação de dependência alcançado foi reduzido.

Tais resultados permitem constatar que mesmo estas práticas, as fronteiras tecnológicas possíveis, têm niveis de utilização baixos e, portanto, a venda da carne bovina in natura ainda não encontra-se satisfatoriamente próxima de uma fronteira tecnológica de padronização. Como no recebimento há práticas de padronização com elevados niveis de utilização, percebe-se que as lojas da amostra não têm transferido estes níveis para a venda da carne. Ou seja, os elevados níveis de utilização de algumas práticas de padronização no recebimento da carne bovina se perdem na entrada da carne na loja e não são transferidos para práticas padronizadas dentro das lojas.

Uma conclusão a que se pode chegar é a de que talvez as práticas de padronização utilizadas até a entrega da carne na loja estejam indo de encontro aos interesses de padronização das lojas dos supermercados. Dito de outra forma, pode ser que as práticas de padronização mais utilizadas no recebimento da carne não estejam de acordo com o objetivo de redução de custos pelas lojas e estejam, na verdade, obstruindo a padronização também na venda da carne. 


\subsection{Teste da hipótese dois.}

A hipótese dois revisitada:

2) a distância de uma loja da fronteira tecnológica da padronização na comercialização de carne bovina in natura é inversamente relacionada à capacidade de coordenação de fornecedores por parte da loja. Espera-se que as lojas que coordenam mais os fornecedores estejam mais próximas de uma fronteira tecnológica hipotética de padronização.

Ao contrário da hipótese um, pode-se afirmar que existe- uma relação de dependência entre a coordenação de fornecedores e a adoção de procedimentos padronizados na comercialização de carne bovina in natura. Pelo menos na maioria das proxys escolhidas para a coordenação de fornecedores, ou pelo menos nas de menor nível de utilização, tal comportamento pode ser observado. A hipótese dois então pode ser aceita, em alguns casos com elevado nível de significância estatística. As tabelas $22 \mathrm{~A}, 22 \mathrm{~B}$ e $22 \mathrm{C}$ mostram o resultado dos testes.

A tabela 22A mostra o teste de dependência entre um primeiro grupo de proxys de coordenação de fornecedores e algumas variáveis de padronização selecionadas. As variáveis de padronização selecionadas são as que apresentaram maior significância estatística no teste de dependência em relação ao tamanho das lojas, como mostrado no item 4.2 .

Começando a delinear um comportamento comum para os três grupos (tabelas 22A, 22B e 22C), estas três primeiras apresentam maior nível de significância para a dependência em relação ao uso de procedimentos padronizados quando o nível de prática de coordenação é mais baixo.

Observa-se que a preferência na descarga para entrega em horário programado não mostra relação de dependência com nenhum dos tipos de padronização considerados. Tal fato é corroborado pelo alto índice de utilização desse tipo de coordenação de fornecedores. Como esta é uma prática difundida, não há relação de 
dependência com a padronização. Ou seja, não necessariamente onde há maior adoção de preferência na descarga para entrega em horário programado há maior padronização de processos na comercialização de carne bovina in natura. $\mathrm{O}$ mesmo ocorre para a prática de preços diferenciados para a entrega da carne desossada.

Tabela 22A. Teste para avaliação da dependência entre proxys de coordenação de fornecedores na comercialização de carne bovina in natura em supermercados e proxys de padronização.

\begin{tabular}{|c|c|c|c|c|c|c|}
\hline \multirow[t]{2}{*}{ Tipo de Padronização } & \multicolumn{2}{|c|}{$\begin{array}{c}(1) \\
30,56 \% \text { (a) }\end{array}$} & \multicolumn{2}{|c|}{$\begin{array}{c}(2) \\
41,67 \%(a)\end{array}$} & \multicolumn{2}{|c|}{$\begin{array}{c}(3) \\
72,22 \%(a)\end{array}$} \\
\hline & $\overline{X^{2} \text { CALC }}$ & Sign & $\mathrm{X}^{2}$ CALC & Sign & $\mathrm{X}^{2}$ CALC & Sign \\
\hline $\begin{array}{l}\text { Recebimento de carne desossada e } \\
\text { embalada em peças }\end{array}$ & 3,3737 & - & 9,0996 & - & 11,1592 & $10,00 \%$ \\
\hline $\begin{array}{l}\text { Recebimento de carne desossada e } \\
\text { embalada em cortes prontos, } \\
\text { paletizada }\end{array}$ & 4,0228 & - & 12,4330 & - & 15,3106 & $2,5 \%$ \\
\hline $\begin{array}{l}\text { Venda de carne embalada com } \\
\text { código de barras }\end{array}$ & 3,5625 & - & 4,8313 & - & 3,3425 & - \\
\hline $\begin{array}{l}\text { Venda de carne embalada com } \\
\text { etiqueta de identificação completa }\end{array}$ & 1,1053 & - & 2,9021 & - & 3,2660 & - \\
\hline
\end{tabular}

(a) Nível de prática. Refere-se a "Não utilizam".

(1) Preferência na descarga para entrega em horário programado

(2) Preços diferenciados para carne desossada

(3) Preços diferenciados para entrega de carne pronta para venda

Fonte: Pesquisa de campo.

A grande maioria $(72,22 \%)$ das lojas não utiliza a prática de preços diferenciados para entrega de carne pronta para venda. É neste caso que ganha importância a relação de dependência entre coordenação e padronização. Quanto maior a prática de preços diferenciados para entrega da carne pronta para venda (boxed beefs e consumer units) maior é a adoção de procedimentos padronizados, pelo menos no que se refere ao 
recebimento de carne desossada e embalada em peças e ao recebimento de carne desossada e embalada em cortes prontos, paletizada. Tal afirmativa é estatisticamente comprovada pelo nível de significância do teste de dependência entre estas variáveis (tabela 22A). Assim, aceita-se a hipótese de que quanto mais a loja coordena o fornecedor, mais próxima ela está de uma fronteira tecnológica de padronização.

A padronização na venda da carne bovina in natura não guarda relação de dependência com a coordenação de fornecedores ou, pelo menos, com as variáveis de coordenação mostradas na tabela $22 \mathrm{~A}$. Tal fato é esperado já que a padronização na venda da carne bovina deve estar relacionada mais a aspectos internos da loja, como o nível de conhecimento de novas tecnologias e o uso destas, que, como já verificado, são baixos no caso da amostra.

Tabela 22B. Teste para avaliação da dependência entre proxys de coordenação de fornecedores na comercialização de carne bovina in natura em supermercados e proxys de padronização.

\begin{tabular}{l|c|c|c|c|c|c}
\hline \multirow{2}{*}{ Tipo de Padronização } & \multicolumn{2}{|c|}{$\begin{array}{c}\text { (4) } \\
63,89 \% \text { (a) }\end{array}$} & \multicolumn{2}{c|}{$\begin{array}{c}\text { (5) } \\
\text { 83,33\% (a) }\end{array}$} & \multicolumn{2}{c}{$50,00 \%$ (a) } \\
\cline { 2 - 7 } & $\mathrm{X}^{2}$ cALC & Sign & $\mathrm{X}^{2}$ calc & Sign & $\mathrm{X}^{2}$ caLc & Sign \\
\hline $\begin{array}{l}\text { Recebimento de carne desossada e } \\
\text { embalada em peças }\end{array}$ & 9,6092 & - & 14,5734 & $2,5 \%$ & 8,8221 & - \\
\hline $\begin{array}{l}\text { Recebimento de carne desossada e } \\
\text { embalada em cortes prontos, } \\
\text { paletizada }\end{array}$ & 19,0294 & $0,50 \%$ & 19,6727 & $0,50 \%$ & 13,0963 & $2,5 \%$ \\
\hline $\begin{array}{l}\text { Venda de carne embalada com } \\
\text { código de barras }\end{array}$ & 4,6213 & - & 6,0853 & - & 7,6925 & - \\
\hline $\begin{array}{l}\text { Venda de carne embalada com } \\
\text { etiqueta de identificação completa }\end{array}$ & 4,0232 & - & 3,9111 & - & 3,1950 & - \\
\hline
\end{tabular}

(a) Nível de prática. Refere-se a "Não utilizam".

(4) Preços diferenciados para entrega da carne embalada.

( 5 ) Preferência na descarga para entrega da carne paletizada.

(6) Preços diferenciados para identificação de origem.

Fonte: Pesquisa de campo. 
A tabela 22B comprova mais uma vez a constatação de que, considerando-se as práticas de coordenação menos utilizadas há uma relação estatisticamente comprovada de dependência entre coordenação e padronização.

Portanto, dentro da fronteira possível para a coordenação (práticas mais utilizadas) não há relação de dependência com a padronização. Nestes casos, a padronização ocorre mesmo onde há pouca coordenação. Mas quando considera-se a fronteira limite para a coordenação (práticas menos utilizadas), estabelece-se a relação de dependência, ou seja, na fronteira limite ocorre maior utilização de procedimentos padronizados de comercialização de carne bovina in natura quando ocorre maior coordenação de fornecedores.

É o caso da prática de preferência na descarga para entrega de carne paletizada. Cerca de $83 \%$ das lojas da amostra afirmaram não praticar este tipo de coordenação. Neste caso, a relação de dependência com o recebimento de carne desossada e embalada em peças teve significância ao nível de $2,5 \%$ e, como pode-se esperar, a significância da dependência em relação ao recebimento de carne desossada e embalada em cortes prontos, paletizada, atingiu o nível de $0,5 \%$.

Esta última significância é interessante pois, trabalha-se, tanto no caso da proxy para a padronização (recebimento de carne desossada e embalada em cortes prontos, paletizada), quanto no da proxy para a coordenação (preferência na descarga para entrega de carne paletizada) com as fronteiras limite em ambos os grupos de variáveis. $O$ que se pretende afirmar é que as lojas que trabalham na fronteira da coordenação também trabalham na fronteira da padronização, o que se encaixa na aceitação da hipótese dois.

Considera-se também as práticas de contratação de fornecedores de came bovina in natura. A tabela $22 \mathrm{C}$ apresenta as relações de dependência entre as práticas de contratação e a adoção de padronização nas lojas (tipos de padronização escolhidos). Em todas as práticas de contratação consideradas encontrou-se elevada significância estatística para a dependência entre coordenação e padronização no recebimento de carne pela loja. 
Tabela 22C. Teste para avaliação da dependência entre proxys de coordenação de fornecedores na comercialização de carne bovina in natura em supermercados e proxys de padronização.

\begin{tabular}{|c|c|c|c|c|c|c|}
\hline \multirow[t]{2}{*}{ Tipo de Padronização } & \multicolumn{2}{|c|}{$\begin{array}{c}(7) \\
86,11 \%(a)\end{array}$} & \multicolumn{2}{|c|}{$\begin{array}{c}(8) \\
80,56 \%(a) \\
\end{array}$} & \multicolumn{2}{|c|}{$\begin{array}{c}(9) \\
69,44 \%(a) \\
\end{array}$} \\
\hline & $\mathrm{X}^{2}$ CALC & Sign & $\mathrm{X}^{2}$ CALC & Sign & $\mathrm{X}^{2}$ CALC & Sign \\
\hline $\begin{array}{l}\text { Recebimento de came desossada e } \\
\text { embalada em peças }\end{array}$ & 18,5346 & $1,00 \%$ & 12,9501 & $5,00 \%$ & 12,8335 & $5,00 \%$ \\
\hline $\begin{array}{l}\text { Recebimento de carne desossada e } \\
\text { embalada em cortes prontos, } \\
\text { paletizada }\end{array}$ & 19,7091 & $0,50 \%$ & 18,0188 & $1,00 \%$ & 20,4550 & $0,50 \%$ \\
\hline $\begin{array}{l}\text { Venda de carne embalada com } \\
\text { código de barras }\end{array}$ & 8,6546 & - & 5,7701 & - & 4,6150 & - \\
\hline $\begin{array}{l}\text { Venda de came embalada com } \\
\text { etiqueta de identificação completa }\end{array}$ & 4,3499 & - & 2,7211 & - & 5,5816 & - \\
\hline
\end{tabular}

(a) Nivel de prática. Refere-se a "Não utilizam".

(7) Contrato fixando preços.

( 8 ) Contrato fixando preços e frequiência de entrega.

(9) Contrato fixando preços, a freqüência de entrega e exigências sobre a qualidade.

Fonte: Pesquisa de campo.

O tipo de contratação mais usual é a que faz exigências sobre preços, freqūência de entrega e qualidade da carne. Ressalta-se que mesmo este tipo de contratação tem um nível de utilização não muito considerável (cerca de $69 \%$ dos participantes afirmaram não utilizar este tipo de coordenação). No caso deste tipo de contratação, há uma forte dependência da padronização. A significância estatística para esta relação situa-se em 0,5\%. Assim, quanto mais usa-se a contratação da forma mais completa considerada, mais são utilizados os procedimentos padronizados (neste caso o recebimento de carne desossada e embalada em cortes prontos, paletizada).

Quanto ao tipo de contratação menos usual (preços), há também uma relação de dependência entre coordenação e padronização. Tal relação é até mais significativa do que no caso do tipo mais usual. No geral, pode-se aceitar a hipótese dois a partir da 
significância estatística destas relações de dependência.

Contudo, tal conclusão só é válida para o caso do recebimento da carne na loja. Novamente, não ocorre qualquer relação de dependência entre os tipos de contratação considerados e a padronização na venda de carne bovina in natura. Em primeiro lugar pelo fato de o recebimento de carne em peças se transformar em, muitas das vezes, venda de carne desembalada e sem código de barras, como visto anteriormente.

Assim, deve estar ocorrendo algum fator dentro das lojas que pode estar "quebrando" o processo de padronização completo. Acredita-se que o custo envolvido com a montagem de uma equipe de preparação de carnes para exposição em gôndolas só seja viável por enquanto em grandes lojas, já que o produto gira mais. Nas pequenas lojas, a restrição financeira restringe o uso do auto-serviço já que o produto gira pouco e, desta forma, torna-se mais interessante o atendimento pessoal do açougueiro. Ocorre também de haver convivência dos dois tipos de atendimento (auto-serviço e pessoal). Neste caso, é a pequena proporção do que é vendido em auto-serviço que talvez ainda não permita a manutenção da padronização completa.

\subsection{Teste da hipótese três.}

A hipótese três revisitada:

3) Espera-se que as maiores lojas estejam mais próximas de uma fronteira tecnológica hipotética de coordenação;

A coordenação pode ter associação com o tamanho da loja. É o que mostra a tabela 23. Nesta tabela tem-se que, excetuando-se a preferência na descarga para entrega em horário programado, todas as variáveis de coordenação consideradas têm relação de dependência, com significância estatística, com o tamanho da loja.

Isto indica que quanto mais se aproxima da fronteira tecnológica de coordenação de fornecedores, mais se aproxima das maiores lojas da amostra. Tal resultado vale tanto para o que consideramos uma fronteira "possível" (práticas mais utilizadas, como os 
preços diferenciados para identificação de origem) como para o que consideramos uma fronteira "limite" (práticas menos utilizadas como o contrato fixando preços).

Tabela 23. Teste para avaliação da dependência entre proxys de coordenação de fornecedores na comercialização de carne bovina in natura em supermercados e o tamanho da loja.

\begin{tabular}{|c|c|c|c|c|c|c|}
\hline & & Nível de utilização & $\mathrm{X}^{2}$ LOJA & $\mathrm{X}^{2}{ }_{10 \%}$ & $\mathrm{X}_{5 \%}^{2}$ & $\mathrm{X}_{1 \%}^{2}$ \\
\hline \multirow{9}{*}{ Tipo de Coordenação } & (1) & $30,56 \%$ & 17,0711 & 18,5493 & 21,0261 & 26,217 \\
\hline & (2) & $41,67 \%$ & 18,6025 & 18,5493 & 21,0261 & 26,217 \\
\hline & (3) & $72,22 \%$ & 18,8332 & 18,5493 & 21,0261 & 26,217 \\
\hline & (4) & $63,89 \%$ & 18,9736 & 18,5493 & 21,0261 & 26,217 \\
\hline & (5) & $83,33 \%$ & 23,3741 & 18,5493 & 21,0261 & $\overline{26,217}$ \\
\hline & (6) & $50,00 \%$ & 28,4799 & 18,5493 & 21,0261 & 26,217 \\
\hline & (7) & $86,11 \%$ & 19,9900 & 18,5493 & 21,0261 & 26,217 \\
\hline & (8) & $80,56 \%$ & 20,0232 & 18,5493 & 21,0261 & 26,217 \\
\hline & (9) & $69,44 \%$ & 20,3227 & 18,5493 & 21,0261 & 26,217 \\
\hline
\end{tabular}

(a) Nível de prática. Refere-se a "Não utilizam".

(1) Preferência na descarga para entrega em horário programado

(2) Preços diferenciados para carne desossada

(3) Preços diferenciados para entrega de carne pronta para venda

(4) Preços diferenciados para entrega da carne embalada.

(5) Preferência na descarga para entrega da carne paletizada.

(6) Preços diferenciados para identificação de origem.

(7) Contrato fixando preços.

(8) Contrato fixando preços e frequiência de entrega.

(9) Contrato fixando preços, a frequiência de entrega e exigências sobre a qualidade.

Fonte: Pesquisa de campo.

Assim, quanto maior o tamanho da loja, maior é a prática de coordenação de fornecedores e a hipótese três pode ser aceita. Ressalta-se novamente que práticas como a preferência na descarga para entrega de carne paletizada, consideradas como a fronteira limite no recebimento de carne pela loja, atingem níveis de significância mais elevados para a relação de dependência com o tamanho da loja. Por outro lado, práticas 
mais utilizadas, consideradas como a fronteira possível, atingem níveis de significância menores ou até insignificantes, como no caso da preferência na descarga para entrega em horário programado. 


\section{CONCLUSÕES}

$O$ objetivo deste trabalho era o de fornecer aos supermercados e às entidades responsáveis pela difusão do $\mathrm{ECR}$ no Brasil um posicionamento no que se refere à fronteira tecnológica (melhores práticas) de padronização na comercialização de carne bovina in natura. Acredita-se que este objetivo foi atingido na medida em que, diante das proxys escolhidas, foi possivel determinar quais são as práticas mais utilizadas e as menos utilizadas pelos supermercados da amostra que, como mostrado, atende à proporcionalidade dos estratos de tamanho da população pesquisada.

As práticas mais utilizadas de padronização no recebimento de carne bovina in natura mostraram-se difundidas por todos os estratos de tamanho de lojas considerados, já que os testes de dependência para a relação entre padronização e o tamanho mostraram-se não significativos do ponto de vista estatístico. Já as práticas menos utilizadas mostraram-se mais dependentes do tamanho da loja, já que o teste de dependência definiu níveis de significância reduzidos, mas bem superiores aos das práticas mais utilizadas. Tal resultado demonstra, com falhas, que pode existir uma relação de dependência entre a adoção de procedimentos estáveis e padronizados no recebimento de carne bovina in natura e o tamanho das lojas.

No que se refere à venda de carne bovina in natura, os testes estatísticos demonstraram não haver dependência em relação ao tamanho das lojas. Este resultado, somado ao baixo nível de utilização de todas as práticas citadas, demonstra uma quebra do processo de padronização completo ao longo da cadeia de suprimento dentro das lojas dos supermercados. Assim, mesmo que as maiores lojas utilizem mais procedimentos padronizados no recebimento da carne, não o estão fazendo na venda. 
Além disso, constatou-se que a adoção de procedimentos padronizados no recebimento de carne bovina in natura relaciona-se diretamente ao maior uso de práticas de coordenação de fornecedores. Na venda da carne, novamente, não foi possível estabelecer diferenças estatísticas na proporção de pequenas, médias e grandes lojas que coordenam fornecedores e utilizam procedimentos padronizados. A relação de dependência entre a padronização no recebimento de carne bovina in natura e a coordenação de fornecedores apresentou consideráveis níveis de significância estatística, demonstrando que lojas que coordenam mais os fornecedores recebem a carne de uma forma mais padronizada. Este foi outro tipo de posicionamento que pôde ser oferecido aos supermercados e às entidades envolvidas com o ECR.

Considerando as práticas de coordenação menos usuais, a relação de dependência com a padronização aumenta, obtendo maiores niveis de significância estatística. Assim, como no caso da relação entre padronização e tamanho, há um conjunto de firmas que operam na fronteira da coordenação e, conseqüentemente, na fronteira da padronização no recebimento de carne bovina in natura.

Tal relação é reforçada com o resultado obtido no que se refere à relação de dependência entre coordenação e tamanho das lojas. Constatou-se que quanto mais existe coordenação de fornecedores, mais próximo fica-se das maiores lojas. Assim, um terceiro posicionamento é mostrado. Quanto maior a loja de supermercado, é estatisticamente esperado que ocorra uma maior prática de coordenação de fornecedores.

A partir desta terceira relação, confirma-se a dúvida sobre o resultado do teste sobre a hipótese de dependência entre padronização e tamanho, que mostrou-se não significativo. Há relação de dependência entre padronização e coordenação e entre coordenação e tamanho, o que leva ao entendimento de que houve alguma falha na condução dos trabalhos para a correta identificação e comprovação estatística da hipótese de dependência entre padronização e tamanho.

Foi mostrado o baixo nível de conhecimento e utilização de instrumentos de negócio diretamente relacionados ao ECR. Tal resultado demonstra o que se chamou de maior ou a menor relutância dos tomadores de decisão em relação à nova prática de 
negócios, que no caso é maior. Demonstra também o que se chamou anteriormente de diferenças na infra-estrutura de tecnologia de informação corrente, que no caso são significativas. Contudo, os resultados mostraram também existir uma considerável demanda por treinamento e investimentos em pessoal nesta área de novas tecnologias de informação, dada a importância atribuida para este item como uma importante variável competitiva e a forte demanda das lojas por medidas relacionadas a esta área no intuito de se reduzir custos.

De uma forma geral, os resultados mostraram as dificuldades impostas pelas especificidades do setor supermercadista à implantação efetiva de estratégia como a gestão de cadeias de suprimento e o ECR. Existe uma disparidade considerável nas práticas de padronização e coordenação no que se refere ao tamanho da loja considerada. Assim, a efetiva implantação de estratégias de regularização de fluxo fisico e financeiro de produtos visando atender diretamente aos hábitos de compra dos consumidores (fundamento do ECR), no caso da carne bovina in natura, deve considerar esta disparidade e propor medidas de equalização das oportunidades para todos os tamanhos de lojas, caso este seja o objetivo de tais estratégias. Caso contrário, prevê-se uma maior concentração do mercado para lojas maiores, que estariam mais aptas a enfrentarem as exigências de adaptações para o atendimento dos pré-requisitos do ECR, a padronização entre eles.

Algumas prospeç̧ões de mercado podem ser feitas a partir dos resultados obtidos. Defende-se, em primeiro lugar, que não é esperada uma "revolução" na cadeia de suprimento de carne bovina in natura, diante da possibilidade de implementação de estratégias de gestão de cadeias de suprimento. A pergunta que deve orientar o entendimento das mudanças diferenciadas ao longo da cadeia da carne bovina é: a qual segmento da curva de demanda está sendo feita referência?

Retomando-se o conceito de Efficient Consumer Response (ECR), ou Resposta Eficiente ao Consumidor, pode-se criticá-lo afirmando que ele pode ser apenas mais um modismo das técnicas de administração de empresas. No entanto, mesmo que sua implementação seja discutível, a gestão de cadeias de suprimento, que é o conceito 
logístico que deu origem ao ECR, já considera a importância da demanda final enquanto a "grande coordenadora" das cadeias produtivas. O ECR inova ao realçar a importância crucial das informações de demanda final para as cadeias produtivas se tornarem mercadologicamente mais eficientes. É o que os especialistas em marketing afirmam: de que adiantam os pesados investimentos em eficiência operacional (que sem sombra de dúvida são importantes) se o produto final não está de acordo com as exigências e preferências da demanda.

A eficiência mercadológica estaria vinculada então à disponibilidade e à possibilidade de uso da informação gerada pelo hábito de compra do consumidor. Disponibilidade e possibilidade de uso de informação são duas dimensões diferentes, sendo que ambas referem-se, contudo, à disponibilidade de tecnologia de informação e à compatibilidade desta tecnologia ao longo da cadeia produtiva, como demonstra a literatura a respeito da supply chain management.

Tratando-se de disponibilidade e compatibilidade de tecnologias de informação, trata-se de maior ou menor capacidade de investimento (disponibilidade de recursos para investir), o que pode ser determinado, ceteris paribus, pelo poder de mercado (mesmo no conceito neoclássico de preço maior do que o custo marginal) e, conseqüentemente, pela elasticidade-preço da demanda (segundo a relação estabelecida pelo grau de monopólio de Lerner).

Assim, a maior ou a menor possibilidade de implementação efetiva de estratégias como o ECR (que engloba conceitos como a padronização, certificação, desenvolvimento de marcas, coordenação e competição no varejo) relaciona-se à especificidade das estruturas de mercado nas mais diferentes etapas da distribuição. $\mathrm{Ou}$ seja, qual é a característica da demanda que cada agente de cada etapa da cadeia produtiva enfrenta.

Considerando-se os agentes que, ao longo da cadeia, enfrentam a porção menos elástica (classes de renda mais alta, no caso de agentes do varejo, restaurantes finos, grandes redes do varejo e exportações "qualificadas", no caso de agentes do atacado e processamento, como os frigoríficos, e frigoríficos do grupo estratégico que atende a 
porções de demanda menos elásticas), espera-se uma maior observância de modelos de coordenação orientados inicialmente por redes varejistas, desde a compra de insumos pela produção primária até a venda ao comprador final (exemplos: Carrefour, Pão de Açúcar, Outback Steakhouse, redes importadoras européias). Com isto, ganham importância os conceitos de padronização, certificação, rastreabilidade, desenvolvimento de marcas, sistemas de precificação sofisticados e, obviamente, os agentes distribuídos ao longo da cadeia poderão ter acesso a uma porção da demanda disposta a pagar pela "descomoditização" da carne.

Neste caso, a competição do varejo tenderá a ocorrer através da diferenciação de produtos, ao invés da concorrência em preços. Como trabalha-se com uma demanda menos sensível a preços, é o conjunto de diferenças entre "as carnes" que determinarão a escolha do consumidor. Obviamente que, caso tratar-se de grandes varejistas, as externalidades de consumo de outros produtos tendem a favorecer os agentes da cadeia de suprimento que se adequarem a este cenário.

Sobre a cadeia produtiva à montante espera-se impactos sobre os elos de ligação entre as etapas, como o transporte de boi vivo e de carcaças, que se dará de forma distinta ao observado na maioria das transações atuais. A "internalização" de etapas de produção sob a coordenação de uma mesma firma específica tende a forçar o desaparecimento, no que se refere à porção de demanda menos elástica, de "transportadores de carcaças" e de "leilões de gado", por exemplo.

Destaca-se o caso americano de comercialização de gado Angus e Hereford que, com a chancela do Departamento de Agricultura (USDA), apresenta ao consumidor cerca de quarenta "tipos de carne bovina" diferenciados no que se refere a percepções extra-preço. Portanto, no Brasil, espera-se que a própria natureza da tipologia do rebanho permita a diferenciação para atender a esta demanda, já que algumas raças como Hereford e Brangus têm pequena participação no total do rebanho e, por isso, podem se diferenciar.

Os agentes ganhadores neste "cenário" seriam aqueles que se engajarem em modelos de coordenação conforme apresentados pelo trabalho. Os perdedores seriam os 
que, mesmo com a possibilidade de se enquadrarem, não o fizerem. Seria o velho argumento da "agregação de valor" atuando novamente.

No caso dos frigorificos, por exemplo, os que, fazendo parte do grupo estratégico que atende a uma porção de demanda menos elástica, procuram adotar parcerias e alianças com produtores e varejistas, devem ser os ganhadores. Já os que também fazem parte deste grupo estratégico que não pensarem nesta hipótese podem estar caminhando para uma posição de concorrência muito mais seletiva no mercado (concorrência em preços, num mercado que não é sensivel a preços).

Já para segmentos de demanda mais elástica, não espera-se a curto prazo a observância de estratégias como a padronização, a coordenação, a rastreabilidade, as marcas e a competição no varejo ocorrerá ainda fundamentada no aspecto preço. Contudo, a médio e a longo prazos o fato de as estratégias de coordenação estarem sendo implementadas principalmente por redes varejistas pode trazer impactos sobre a comercialização de carne bovina in natura também para a porção de demanda mais elástica.

É neste segmento principalmente que vem se fundamentando o crescimento das vendas dos super e hipermercados no Brasil, graças à introdução de inovações como a venda à prazo e a fidelização, que nada mais é do que uma "caderneta de compras" da era digital. Assim, se o segmento de demanda mais sensível a preços vem se deslocando para a compra em redes de auto-serviço, espera-se que a externalidade de consumo possa aumentar a participação de produtos diferenciados (como a carne) na cesta de consumo deste segmento (“já que vou pagar a prazo mesmo...").

Portanto, à medida que o consumidor deste segmento procura a loja para comprar outros produtos e depara-se com a proposta de uma carne diferenciada, com sabor característico e, no limite, processo de produção controlado e rastreável, pode estar surgindo mais demanda por "descomoditização" da carne bovina.

Caso isto seja factível a médio e a longo prazos, ai sim espera-se uma verdadeira "revolução" no estado das artes da distribuição de carne bovina in natura. Com a 
concentração de compras para o lar em auto-serviços, prevê-se uma derrocada de varejos tradicionais, assim como já ocorre em algumas regiões do mundo. Além disto, produtores e processadores outstream deste processo de padronização, certificação, rastreabilidade, desenvolvimento de marcas e outros, tendem a enfrentar uma seletividade maior e, até mesmo, a exclusão do mercado.

Ressalta-se que para isto deve haver informação disponível e compartilhada, o que restringe sobremaneira a distância entre o curto e o que chama-se de médio-longo prazos.Atuando positivamente para a aceleração do processo encontra-se a externalidade de consumo.

Portanto, cabe aos agentes da cadeia, em suas várias etapas, identificar a qual demanda estão atingindo ou querendo atingir $e$, desta forma, adequarem-se às variáveis competitivas a eles impostas.

O efeito-graduação, ou seja, a mudança de faixas de demanda pelos agentes é também esperada, principalmente através de reconversão de ativos (plantas industriais, por exemplo), especialização produtiva e fusões e aquisições (concentração de capital), em todas as etapas da cadeia de suprimento.

A principal limitação deste trabalho relaciona-se ao conceito de fronteira tecnológica utilizada. Não se pode afirmar que, com base nos resultados deste trabalho, as melhores práticas na comercialização de carne bovina in natura utilizadas pelos supermercados e identificadas como aquelas que supostamente (a definição de quais práticas seriam as melhores baseou-se em informações de caráter especulativo) seriam as práticas de fronteira no que se refere à eficiência econômica propriamente dita.

Isto se deve em parte ao fato de que o próprio setor supermercadista carece de estudos no sentido de se comprovar que o uso de ferramentas como a padronização e a coordenação de fornecedores pode realmente levar a firma supermercadista a operar na fronteira tecnológica de comercialização de carne bovina in natura. Surge então uma primeira indicação para pesquisas futuras. A necessidade de se quantificar as vantagens econômicas de modelos de comercialização mais padronizados abre espaço para 
pesquisas sobre a gestão de cadeias de suprimento.

Para tanto, indica-se o uso de métodos de quantificação de custos não tradicionais, como o método $\mathrm{ABC}$ de custeio, que foge aos padrões dos métodos de absorção e rateio, por exemplo, e encaixa-se perfeitamente nas estratégias de gestão de cadeias de suprimento. Chegou-se a considerar a possibilidade de utilizar dessa metodologia neste trabalho, mas as especificidades da pesquisa reorientaram-na para a direção aqui tomada.

Outra limitação refere-se ao conceito de cadeia de suprimento considerada. Obviamente, uma cadeia de suprimento engloba todas as fases do processo produtivo, no caso realizadas por unidades econômicas diferentes (desintegração vertical). Assim, o estudo das estratégias de gestão de cadeias de suprimento deve procurar considerar todas estas fases como, no caso deste trabalho, a produção primária, o processamento e a distribuição de carne bovina in natura. A ênfase dada neste trabalho foi na relação entre supermercado (um dos agentes da fase de distribuição) e frigorífico (um dos agentes da fase de processamento).

Assim, muitas informações relacionadas à padronização e à coordenação de fornecedores podem estar sendo "sonegadas" pelo fato de se abstrair as outras fases do processo produtivo. Obviamente, ganharia-se em termos de resultados e conclusões mas perderia-se em termos de custos da pesquisa, fato que pesou na decisão favorável à simplificação. A proposição de novas pesquisas deve abordar essa possibilidade de ampliação da análise para as outras fases do processo produtivo ou da cadeia de suprimento.

Além destas duas limitações, o fato de se considerar especificamente a cadeia de suprimento da carne bovina in natura não permite avaliar a real viabilidade de estratégias como o ECR para o setor supermercadista brasileiro. Assim, a conclusão aqui retirada de que a viabilidade a curto prazo do ECR está comprometida refere-se especificamente para o caso da carne, e não pode de forma alguma ser generalizada para o caso de outros produtos. 
Desta forma, a pesquisa em torno da viabilidade de estratégias de gestão de cadeias de suprimento deve, obrigatoriamente, considerar o caso de várias categorias de produtos. Ou seja, uma pesquisa abrangente sobre a gestão de cadeias de suprimento deve considerar, além da carne (produto pertencente à categoria perecíveis), outras categorias de produtos, como mercearia, higiene e beleza e eletro-eletrônicos. Surge então a necessidade de pesquisas adicionais voltadas para análises mais universais (no que se refere aos tipos de produtos considerados).

Enfim, uma pesquisa sobre a real viabilidade de implantação de estratégias como a gestão de cadeias de suprimentos deve considerar todas estas ampliações sobre este trabalho. Os insights aqui proporcionados visam apenas realizar uma simplificação de um estudo mais completo, que poderia inclusive ser realizado por diferentes pesquisadores, em locais diferentes, formando uma rede de estudos sobre a questão da gestão de cadeias de suprimentos, no caso dos alimentos, pelo varejo. 


\begin{abstract}
ANEXO A
Histórico das estratégias de crescimento do setor supermercadista brasileiro e a situação financeira das firmas líderes
\end{abstract}

\title{
A.1 Histórico das estratégias de crescimento do setor supermercadista brasileiro
}

A consolidação e a expansão dos supermercados no Brasil iniciou-se na década de 50, segundo Cyrillo (1987). Nesta época, surgiram os primeiros estabelecimentos de auto-serviço, um novo conceito de vendas ao varejo. Foi o primeiro avanço do comércio varejista de alimentos na direção das economias de escala (principalmente técnicas). Com o auto-serviço, os estabelecimentos varejistas puderam economizar mão-de-obra, espaço e estoques por loja. Assim, surgiu a estratégia de crescimento em redes, visando aproveitar as chamadas economias de multiplanta (com diluição de custos fixos e/ou indiretos, maior abrangência de mercados e diminuição do pay-back do investimento total) $)^{22}$.

Além das economias de escala técnicas surgiram também economias de escala pecuniárias. Com o advento das redes e o conseqüente aumento da escala total de operações, os supermercados passaram a comprar grandes volumes de mercadorias, ganhando na negociação de preços e condições de pagamento. $O$ aproveitamento de todas as economias de escala foi possível devido a dois fatores: a grande extensão do 
mercado ainda inexplorado (regional e nacional) e as baixas barreiras à entrada. Devido a este último fator ocorreu, paralelamente ao aumento do tamanho das lojas, o aumento do número de lojas e $\mathrm{o}$ aumento do número de firmas.

A estratégia de crescimento em redes relaciona-se com os períodos de expansão econômica e aos primórdios dos supermercados no Brasil. Com o aumento do número de firmas (e de redes), as fusões e aquisições tornaram-se as principais estratégias de crescimento do setor supermercadista brasileiro. Ainda segundo Cyrillo (1987), o processo de fusões e aquisições é economicamente mais indicado para períodos de retração da demanda agregada (e mesmo nos de expansão), pois não são incorridos "os custos de imobilização, de desenvolvimento de infra-estrutura local, e, talvez mais importante, eliminando a concorrência, e absorvendo estas parcelas do mercado".(Cyrillo, 1987, p. 114).

Há que se considerar ainda o intenso movimento de apoio por parte do governo, através do II PND, à concentração do setor. A idéia dos formuladores de politicas de investimento da época era que um setor supermercadista mais concentrado diminuiria a volatilidade de preços no varejo, favorecendo o objetivo final de controle da inflação.

A criação ou diferenciação de "produtos" (que no caso dos supermercados relaciona-se ao serviço de venda de mercadorias) é outra estratégia de crescimento seguida. Até a década de 70 os supermercados limitavam-se a oferecer gêneros alimentícios, utilidades domésticas e bens de consumo não-duráveis. A partir de então, com o exemplo de sucesso vindo principalmente da França, a existência de economias de escala ainda inexploradas e a identificação de um maior nível de exigência por parte do consumidor ${ }^{23}$, surgiram os hipermercados. Estes estabelecimentos, além de serem maiores em espaço físico e número de itens (incorporando bens de consumo duráveis), passaram a oferecer serviços adicionais como a aceitação de cheques, carregadores, estacionamento amplo e até música ambiente.

\footnotetext{
${ }^{22}$ Aproveitando o exemplo de Cyrillo (1987), com uma lucratividade de $2 \%$ sobre o faturamento o pay-back seria de aproximadamente 6 anos. Com 10 lojas, no entanto, o pay-back cairia para aproximadamente 7 meses.
} 
A conjunção dessas duas últimas estratégias, adotadas com mais vigor durante a década de 70 , proporcionou uma gradual tendência à concentração do setor supermercadista.

Nos anos 80 surge uma nova estratégia de crescimento do setor. Com a crise da dívida externa do início da década o país enfrentou, pelo menos até 1984, uma séria retração da demanda agregada. Assim, seria indicado que as empresas continuassem num processo de fusões e aquisições, como na década anterior. No entanto, talvez pela restrição imposta pelos cortes no financiamento dessas operações ${ }^{24}$, os supermercados viram-se obrigados a adotar outras estratégias para manter o crescimento. A busca de novos mercados, principalmente os de baixa renda, foi a saída encontrada. Criou-se assim um equipamento chamado de lojas de sortimento limitado. O surgimento das lojas de sortimento limitado refere-se às economias de crescimento de Penrose (1959). Como as redes de supermercados já possuíam toda uma estrutura de distribuição montada, além de uma organização administrativa já em funcionamento, a implantação dessas lojas decorreu do aproveitamento das economias derivadas desse conhecimento adquirido ao longo do tempo.

A ampliação da base tecnológica, através da integração vertical e da diversificação das atividades, também foi uma estratégia de crescimento adotada pelo setor nesse período. A diferença dessa para as outras já citadas refere-se justamente à mudança de base tecnológica. Nas estratégias anteriores a base tecnológica (o autoserviço) não era alterada na sua essência. Com a adoção dessa nova estratégia começaram a surgir investimentos na área de distribuição e controle dos fluxos físico e financeiro, de forma a viabilizar a conexão de todo o conglomerado (atividades agrícolas, indústrias e serviços complementares, como transporte, pesquisa e financeiras).

A concentração observada nesse período (década de 50 a década de 80 ) surgiu

\footnotetext{
23 Principalmente a demanda por conveniência, originada do aumento vertiginoso da urbanizaçăo e do crescimento econômico do começo da década.

${ }^{24}$ Mesmo que autores como Cyrillo (1987) afirmem que a fonte de financiamento principal dos supermercados na década de 70 foram os lucros retidos.
} 
então das estratégias de crescimento adotadas pelas firmas do setor. Ressalta-se, porém, que o setor supermercadista é considerado um oligopólio diferenciado com franja (Cyrillo, 1987) ou, segundo a tipologia de Possas (1985), um híbrido entre o oligopólio competitivo e o oligopólio diferenciado. Assim, é mais correto afirmar que a maioria dos processos de concentração do período partiram de iniciativas das firmas líderes nacionais, e mesmo estrangeiras, do que das firmas marginais. Com isso, o que observase é uma concentração do setor e ao mesmo tempo, um movimento de exclusão na margem.

Na década de 90, segundo o BNDES (1996) o que se observa é a consolidação dos grandes equipamentos (hipermercados) como as firmas mais eficientes. É citada nesse trabalho a entrada da rede americana Wal-Mart, modelo internacional no varejo de alimentos, no que se refere à moderna tecnologia de informação e logística de distribuição.

No entanto, o setor se mantém com uma estrutura preservadora da margem, ou seja, um oligopólio diferenciado-competitivo. O que define a manutenção dessa estrutura é a característica do mercado nesse setor. Cada tipo de equipamento tem o seu raio de influência (quanto maior o equipamento maior é o raio de influência, que pode chegar a regiões inteiras de uma área urbana) e isto faz com que ocorram mercados sobrepostos entre grandes e pequenos. Dessa forma, o que define a sobrevivência de cada tipo de equipamento é a necessidade do consumidor, que precisa tanto dos hiper/supermercados para as grandes compras antecipadas, como dos equipamentos tradicionais para as compras emergenciais.

A medida que os grandes equipamentos passam a oferecer cada vez mais serviços complementares e melhores condições de compra, contudo, ressalta-se que a tendência pode ser o enfraquecimento das firmas marginais e uma concentração ainda maior desse mercado.

A introdução das modernas tecnologias de informação e da gestão de cadeias de suprimento (supply chain management) estaria introduzindo, então, um novo padrão de crescimento para as firmas do setor. A condição para o crescimento pode estar se 
tornando, cada vez mais, o investimento no gerenciamento integrado da cadeia.

Questiona-se, porém, a real adaptação do setor (tanto das firmas líderes quanto das marginais) às necessidades impostas para a adoção dessas novas tecnologias. Diante da assimetria das estruturas de custo entre as empresas ${ }^{25}$, já que tratamos de um oligopólio diferenciado, há uma forte pressuposição de que este fato, além de outros, estariam colocando um considerável obstáculo à difusão dessas tecnologias para todo o setor.

\section{A.2 Situação financeira das firmas líderes}

A seguir serâo mostradas algumas informações sobre as firmas líderes do setor supermercadista brasileiro. $\mathrm{Na}$ tabela 24 tem-se alguns indicadores de eficiência operacional. O que destaca-se é a assimetria existente entre estas firmas em todos os indicadores apresentados. Portanto, revela-se aqui mais uma vez a caracterização do setor supermercadista como um oligopólio diferenciado-competitivo, pois além da assimetria existente entre firmas líderes e marginais existe, mesmo dentro do primeiro grupo, uma considerável diferença de capacidade competitiva.

Tabela 24. Indicadores de eficiência operacional das firmas líderes - 1997

\begin{tabular}{lrrrr}
\hline Empresa & $\begin{array}{c}\text { Faturamento } \\
\text { por área } \\
\left(\mathrm{R} \$ \mathbf{m}^{2}\right)\end{array}$ & $\begin{array}{c}\text { Faturamento por } \\
\text { check-out } \\
\text { (R\$/chkt/ano) }\end{array}$ & $\begin{array}{r}\text { Faturamento por } \\
\text { loja (R\$/loja/ano) }\end{array}$ & $\begin{array}{c}\text { Faturamento } \\
\text { por } \\
\text { funcionário }\end{array}$ \\
\hline Carrefour & $10.978,00$ & $1.504 .810,00$ & $112.922 .203,25$ & $271.514,00$ \\
Pão de Açúcar & $10.383,00$ & $1.185 .528,00$ & $15.287 .328,86$ & $185.131,00$ \\
Bompreço & $6.997,00$ & $983.323,00$ & $21.611 .957,69$ & $135.466,00$ \\
Casas Sendas & $10.968,00$ & $1.110 .821,00$ & $29.398 .447,43$ & $149.061,00$ \\
Paes Mendonça & $7.177,00$ & $984.076,00$ & $26.485 .714,29$ & $158.733,00$ \\
Nacional CDA & $\mathbf{8 . 1 4 3 , 0 0}$ & $671.319,00$ & $9.707 .628,82$ & $122.453,00$ \\
Lojas Americanas & $7.414,00$ & $\mathbf{8 2 1 . 0 7 0 , 0 0}$ & $28.915 .926,09$ & $159.813,00$ \\
Zaffari & $11.611,00$ & $1.060 .206,00$ & $35.430 .201,44$ & $115.428,00$ \\
Cia Real de Distr. & $7.531,00$ & $\mathbf{8 8 4 . 7 0 0 , 0 0}$ & $18.552 .676,47$ & $149.406,00$ \\
Rede Barateiro & $7.435,00$ & $\mathbf{8 7 1 . 6 1 1 , 0 0}$ & $17.922 .492,22$ & $112.323,00$ \\
\hline
\end{tabular}

Fonte: ABRAS (1998). 
Com as informações contábeis e financeiras obtidas no Balanço Anual da Gazeta Mercantil obteve-se algumas características interessantes das firmas líderes do setor supermercadista no período considerado (1988-1997).

Ocorre no período a compressão das margens das líderes do setor, que afetou sobremaneira a capacidade de investimento dos supermercados pois, conforme já citado, estes financiam seus investimentos com os lucros retidos. Com a redução dessa fonte de financiamento, a busca por fundos externos provocou o aumento de quase $50 \%$ no endividamento total médio das líderes no período 1988-1997.

O crescimento do endividamento total não se deveu ao aumento das dívidas financeiras, que permaneceram estáveis no período. Com a liquidez equilibrada, as dívidas contraídas com operações financeiras não têm tanta importância sobre a estrutura do endividamento total.

Trabalhando-se com correlações simples chega-se a alguns resultados interessantes. A tabela 25 mostra algumas das correlações simples obtidas entre indicadores econômico-financeiros escolhidos, calculados com dados do Balanço Anual da Gazeta Mercantil. ${ }^{26}$

Tabela 25. Correlações simples entre indicadores escolhidos

\begin{tabular}{ll}
\hline \multicolumn{1}{c}{ Correlação } & Coeficiente \\
\hline Lucro líquido x Investimento & 0,7227764 \\
Dívidas financeiras x Liquidez corrente & $-0,777737$ \\
Liquidez corrente x Investimento & 0,6192002 \\
\hline
\end{tabular}

Fonte: Elaboração própria a partir do Balanço Anual da Gazeta Mercantil.

A alta correlação negativa entre dívidas financeiras e liquidez corrente explica de certa forma o comportamento do primeiro indicador. Como a liquidez manteve-se estável, o endividamento financeiro não evoluiu muito ao longo dos anos. Com a

${ }^{25}$ No conceito de Steindl (1959)

${ }^{26}$ O lucro líquido, por exemplo, é a média dos lucros líquidos anuais das 10 maiores empresas 
considerável correlação entre liquidez e investimento poderia se esperar um comportamento estável desse segundo indicador. Contudo, como a correlação do investimento é mais forte com o lucro líquido, a queda desse último provocou a queda do montante investido pelas líderes do setor supermercadista.

O que se destaca na observação desses indicadores é a restrição imposta pela queda do lucro líquido em proporção da receita operacional líquida no que se refere à capacidade de investimento. Principalmente a partir de 1995 observa-se que a recuperação dos investimentos teve um considerável impacto sobre o endividamento total. Assim, há que se considerar a sustentabilidade desses projetos de investimento mesmo a médio prazo, pois é questionável do ponto de vista de eficiência financeira a busca de fundos externos num momento de altas taxas de juros de mercado. $O$ efeito da taxa de juros pode ser relativizado devido à regularidade do endividamento financeiro observado no período entre as líderes. Contudo, a busca por fundos externos com altas taxas de juros pode afetar o endividamento financeiro num periodo seguinte, afetando também o endividamento total.

Portanto, é nesse contexto de compressão de margens e comprometimento de projetos de investimento que ganham importância as medidas visando a melhoria do processo de distribuição, estocagem e vendas. Se o endividamento é mesmo inevitável, que ele seja feito de forma a melhorar as condições de formação de preços e de rentabilidade. Ganha importância entre as líderes então a adoção das novas tecnologias (EDI e outras) como forma de gerar uma resposta eficiente ao consumidor e, ao mesmo tempo, ganhar eficiência com o gerenciamento integrado da cadeia. 


\section{ANEXO B \\ As novas tecnologias de informação}

Dentre as novas tecnologias apresentadas em Bowersox \& Closs (1996), o intercâmbio eletrônico de dados (EDI-Eletronic Data Interchange), os computadores pessoais, a comunicação por satélite e o sistema de código de barras e de scanning são os que mais se relacionam com a montagem de um sistema de informações integrado.

O EDI é a troca de documentos entre empresas, realizada em formato padrão e entre seus computadores. Duas empresas são consideradas efetivamente interligadas pelo EDI quando elas têm tanto a capacidade de uso do sistema quanto à prática de operação ${ }^{27}$. Dentre as vantagens dessa nova tecnologia cita-se a redução do custo envolvido com a troca de informações na empresa e entre as empresas de uma cadeia produtiva integrada. Além disso, com o EDI ganha-se a possibilidade de obtenção de informação em tempo real, economizando em custos de planejamento, desde a compra até a distribuição de mercadorias às lojas.

Os computadores pessoais, graças principalmente à maleabilidade, são importantes ferramentas para a montagem de sistemas integrados de informação. A possibilidade de montagem de redes de computadores é que garante uma maior agilidade do processo de entrada de dados no sistema integrado.

\footnotetext{
27 Capacidade de uso refere-se à real possibilidade de comunicação entre os computadores. Prática de operação refere-se à habilidade das empresas em utilizarem as informaçöes trocadas.
} 
A comunicação por satélite permite às empresas envolvidas com distribuição de mercadorias por espaços geográficos consideravelmente separados um maior controle do fluxo fisico e dos equipamentos envolvidos. A troca de informações contínua entre frota, loja e centro de distribuição leva a um maior controle e previsão de tempo de entrega e, conseqüentemente, um maior controle do estoque. Ressalta-se que o resultado imediato do investimento neste tipo de tecnologia é a melhoria do atendimento às demandas do consumidor, ao invés de redução de custos, já que o montante a ser investido requer um considerável período de pay-back.

Os códigos de barras e a técnica de scanning surgem também como novas tecnologias indispensáveis à montagem de sistemas de informação integrados. As barras consistem em códigos que podem ser lidos por computadores, colocadas em itens isolados, em embalagens e contêineres.

Tabela 26. Beneficios das tecnologias de identificação automática

- Carregamento: facilitam a preparação e o processamento das ordens; eliminam erros no carregamento; reduzem o tempo de trabalho; facilitam a manutenção de arquivos; reduzem o tempo de estoque físico.

- Transporte: integridade da informação nas cobranças de fretes; acesso ao cliente com

.. informações em tempo real; facilitam a manutenção de arquivos de dados sobre a atividade de carregamento dos clientes; processamento de contêineres simplificado.

- Armazenagem: facilitam a preparação e o processamento das ordens; proporcionam um controle de estoque apurado; acesso ao consumidor com informações em tempo real; redução dos custos com mão-de-obra; etc.

- Atacadistas/Varejistas: Precisão no estoque; acurácia na determinação do preço no ponto de venda; facilita o registro da produtividade por check-out; redução do tempo de estoque físico; etc.

Fonte: Bowersox \& Closs (1996)

A padronização dos códigos é feita por uma tabela universalmente utilizada. Nos primórdios do sistema, pelo UPC (Universal Product Code), criado em 1972 (Bowersox \& Closs, 1996). Com os problemas surgidos na utilização desse padrão, novos formatos foram criados $^{28}$. A tabela 26 apresenta os benefícios das chamadas tecnologias de

${ }^{28} \mathrm{O}$ espaço ocupado pelas barras criou um conflito com os responsáveis pela propaganda do 
identificação, nas quais estão incluídos os códigos de barras.

Já a tecnologia de scanning tem duas aplicações principais na montagem de sistemas de informação integrados. A primeira ocorre no POS (point of sale), que facilita o controle dos estoques ao nível da loja, já que é capaz de registrar cada venda de cada uma das unidades mantidas em estoque ou SKU (StockKeeping Unit). Assim, a sua utilização é amplamente satisfatória para toda a cadeia à montante dos supermercados, já que permite o controle do fluxo de mercadorias e, por conseguinte, o controle dos estoques em todos os níveis da cadeia.

A segunda principal aplicação é no manuseio das mercadorias. A utilização de scanners permite mapear o caminho seguido por uma determinada SKU desde a saida do fornecedor até a venda no check-out. Assim, observa-se uma considerável economia de tempo e trabalho nas atividades envolvidas com a distribuição num primeiro momento e, num segundo momento, na administração financeira e de compras.

O EDI, que dentre as novas tecnologias citadas é a mais importante para a montagem de um sistema de informações integrado, exige, para seu funcionamento, uma padronização de critérios de comunicação e informação. Quanto à comunicação, os padrões mais aceitos atualmente são o ASC X.12 (American Standards Comittee X.12) e - UN/EDIFACT (United Nations/Eletronic Data Interchange For Administration, Commerce and Transport). $\mathrm{O}$ primeiro tem aplicação mais restrita aos Estados Unidos ${ }^{29}$ enquanto o segundo tem espectro mundial e, segundo especialistas, tem atraído cada vez mais adeptos.

Quanto à informação, o padrão é formado pelo chamado transaction set, que lista uma relação de documentos eletrônicos relacionados entre si. Para cada indústria, o transaction set define os tipos de documentos que podem ser transmitidos. Na tabela 27 temos os transaction sets mais utilizados.

A unificação dos transaction sets entre as indústrias é feita pelas chamadas VAN

produto nas embalagens. Surgiram então novos formatos como Code 1, DataCode, Softstrip, VeriCode, Codablock, Code 49, Code 16K e, a mais avançada, a PDF 417.

${ }^{20} \mathrm{O}$ país que tem o mais alto indice de utilização de EDI, segundo Bowersox \& Closs (1996). 
(Value-Added Networks). Ao realizar a interligação entre os vários transaction sets, dizse que essas redes agregam valor à troca de informações. A figura 13 mostra o funcionamento de uma VAN e a sua importância para a manutenção de um sistema de informação integrado.

Tabela 27. Padrões de EDI para indústrias específicas

- UCS (Uniform Communication Standards): alimentos/mercearia.

- VICS (Voluntary Inter-industry Communication Standards Committee: atacadistas.

- WINS (Warehouse Information Network Standards): armazéns.

- TDCC (Transportation Data Coordinating Committee): transportadores.

- AIAG (Automotive Industry Action Group): indústria automobilística.

Fonte: Bowersox \& Closs (1996)

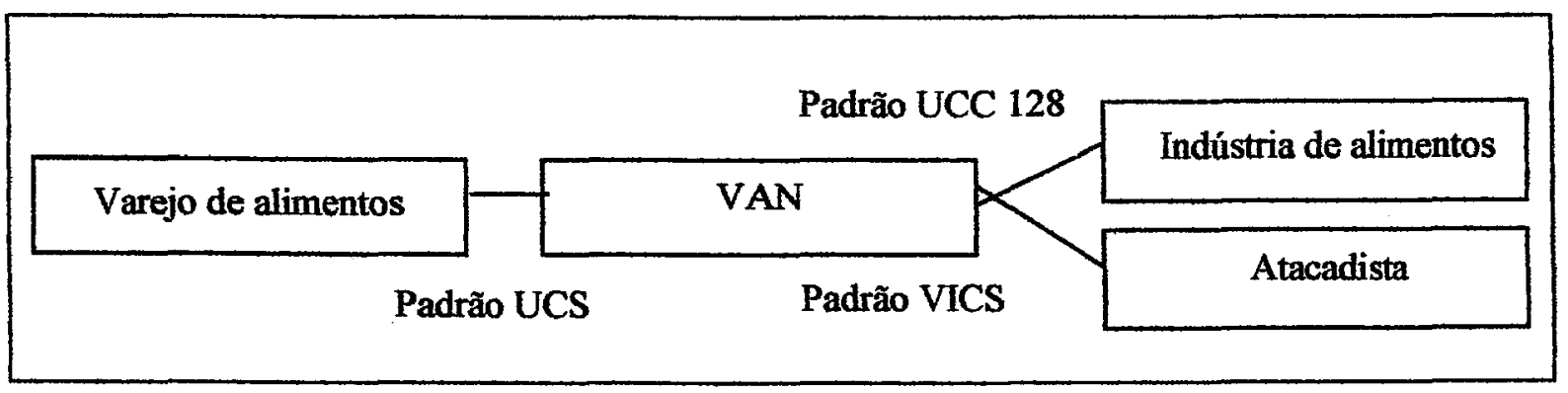

Figura 13. As redes de valor agregado (VAN's)

Fonte: Bowersox \& Closs (1996) 


\section{ANEXO C}

\section{Glossário}

1 EDI - Eletronic Data Interchange - É uma troca automatizada, computador a computador, de informações de negócios estruturadas, entre uma empresa e seus parceiros comerciais de acordo com um padrão reconhecido internacionalmente.

2 ECR - Efficient Consumer Response - É uma estratégia em que o varejista, o distribuidor e o fornecedor trabalham muito próximos para eliminar custos excedentes da cadeia de suprimentos e melhor servir ao consumidor final.

3 Cadeias de suprimento - Supply chains - É o completo processo de abastecimento, desde a busca por matérias-primas para o beneficiamento, até a compra do consumidor final.

4 UPC - Universal Product Code - É uma estrutura numérica desenvolvida para o mercado norte-americano e códigos de barras padronizados para a identificação ao nível do consumo. É compatível com a estrutura usada no Brasil (EAN).

5 POS - Point of sale - É o lugar físico no espaço de vendas do varejista onde se concretiza efetivamente a venda ao consumidor final - caixa registradora ou check-out. Também é utilizado para descrever o equipamento que registra a venda ao consumidor. Hoje é chamado também de EECF - Equipamento Emissor de Cupons Fiscais. Nele pode estar ligado o leitor ótico (scanner).

6 SKU - StockKeeping Unit - É uma cor, um tamanho, sabor ou embalagem de 
produto que requer um código separado para ser distinguido de outros itens.

7 ASC X.12-American Standards Comittee X.12 - É a linguagem definida pelos Estados Unidos para o intercâmbio eletrônico de dados em administração, comércio e transporte. Cada vez mais os Estados Unidos migram para o UN/EDIFACT.

8 UN/EDIFACT - United Nations/Eletronic Data Interchange for Administration, Commerce and Transport - É a linguagem definida pela ONU para o intercâmbio eletrônico de dados em administração, comércio e transporte.

9 Transaction set - É o conjunto de documentos que podem ser trocados eletronicamente entre indústrias diferentes, sem perda da homogeneidade das informações.

10 VAN - Value-Added Networks - É uma empresa que opera serviços de recepção, armazenamento e transmissão de mensagens entre empresas que se comunicam via EDI.

11 CAO - Computer Assisted Ordering - É um sistema operado pelo distribuidor que gera automaticamente pedidos de reposição quando as vendas causam redução dos estoques a um nível pré-determinado.

12 Reposição Contínua - É a prática de parceria entre os membros do canal de distribuição que altera o tradicional processo de reposição de mercadorias de geração de pedidos elaborados pelo distribuidor, baseado em quantidades economicamente convenientes, para a reposição de produtos baseada em previsão de demanda efetiva.

13 Gerenciamento de Categorias - É o processo conjunto entre varejistas e fornecedores que consiste em gerenciar as categorias de produtos como unidades estratégicas de negócios, para produzir resultados comerciais melhorados.

14 VMI - Vendor Managed Inventory - É o processo de gerenciamento de estoques pelos fornecedores.

15 Cross-Docking - É o sistema de distribuição no qual os bens entram e saem de um centro de distribuição, sem ali serem armazenados. Engloba o recebimento, a separação, a conferência, a roteirização e o carregamento de produtos num mínimo 
intervalo de tempo.

16 DSD - Direct Store Delivery - É o método de entrega dos produtos dos fabricantes diretamente nas lojas, sem passar pelo distribuidor, atacadista ou centro de distribuição. $O$ inventário da loja (modelo de estoque e reposição) pode ser gerenciado pelo fornecedor com níveis variáveis de supervisão do varejista, embora a entrada dos produtos seja feita tanto pelo fornecedor quanto pela loja. 


\section{ANEXO D \\ A cadeia da qualidade da carne bovina do CARREFOUR}

A gestão da qualidade do Carrefour ${ }^{30}$ baseia-se num sistema de rastreabilidade completo, desde a produção primária até a venda ao consumidor nas gôndolas das lojas da empresa. Esta estratégia foi institucionalizada principalmente visando a distribuição de perecíveis (a categoria FLV - Frutas, Legumes, Verduras e a categoria Carnes), para garantir a comercialização de produtos padronizados (quanto à sanidade, ao sabor, ao aspecto visual e no que se refere à exploração do meio ambiente) e que atenda aos hábitos de compra dos consumidores.

Quatro diretrizes básicas orientam o programa de gestão da qualidade: 1) o aumento na relação qualidade-preço, 2) a oferta de produtos de confiança (segurança do alimento), 3) a proteção do meio ambiente e 4) o favorecimento de uma agropecuária duradoura (novos modelos de desenvolvimento agrícola). Permeando estas quatro diretrizes estaria, segundo o palestrante, uma relação mais duradoura e fundamentada mais em confiança mútua (negociação) do que em uso de poder comercial (exploração) entre supermercado, processador e produtor primário.

Neste sentido, o programa de gestão da qualidade do Carrefour prevê a elaboração de acordos informais com os produtores dos produtos escolhidos. Tais acordos estabelecem as regras do jogo para o possível fornecedor a ser certificado pela

\footnotetext{
${ }^{30}$ Este anexo apresenta as principais informações obtidas sobre a cadeia da qualidade da carne bovina do Carrefour, em palestra realizada pelo Engenheiro Agrônomo Arnaldo J. J. Eijsink, no
} 
empresa. Assim, pode-se caracterizar o programa como um sistema de certificação privado, orientado pelo último elo de uma cadeia de suprimento. A auditoria sobre a adequação do produtor ao acordo, assim como sobre a manutenção dessa adequação ao longo do tempo, é realizada por um organismo independente, visando justamente impor uma maior transparência ao processo de avaliação e aprovação de fornecedores.

No início do acordo, é elaborado o chamado caderno de encargos, onde são listadas as exigências do Carrefour no que se refere a aspectos relacionados às quatro diretrizes do programa, ou seja, aspectos relacionados tanto às exigências operacionais quanto aspectos relacionados ao meio ambiente e à segurança do alimento. Na palestra não foi possível ter acesso a caderno de encargos completo, mas pelo que pôde ser visto, há uma extensa lista de exigências para que um fornecedor seja considerado apto a participar da cadeia da qualidade.

Do ponto de vista do produtor, a obediência à uma extensa lista de exigências pode ou não representar um expressivo aumento de custos. A possibilidade de haver ou não aumentos de custos relaciona-se ao atual preparo do produtor no que se refere à adoção de sistemas produtivos modernos e estritamente coordenados. O caso de um produtor extremamente rústico representa a possibilidade de aumentos consideráveis de custos e o caso de um produtor extremamente tecnificado o oposto. No que se refere a preços, o programa de gestão de qualidade propõe um sistema de precificação incentivador e, ao mesmo tempo, maleável. Pretende-se pagar um bônus de $5 \%$ para a produção entregue dentro das especificações técnicas impostas pelo caderno de encargos $^{31}$.

O produtor não torna-se totalmente comprometido com a cadeia da qualidade no que se refere à exclusividade. Obviamente, no acordo informal são definidos parâmetros de variação da quantidade de carne entregue por um determinado produtor, o que visa garantir um certo nível de regularidade da oferta em momentos de alta dos preços no mercado (entressafra principalmente). Da mesma forma, pelo lado dos preços o acordo 
informal não restringe a renegociação. Em momentos de alta volatilidade de preços no mercado spot, seria do interesse da cadeia da qualidade a revisão de preços acordados.

Não são abordados pela cadeia da qualidade quaisquer pontos relacionados ao financiamento de produtores interessados, no que se refere à realização de investimentos adicionais na produção (tecnologia, capital de giro, etc.). $O$ incentivo tratado pela cadeia da qualidade restringe-se à questão do bônus do preço e ao apelo de marketing propiciado pelo selo de qualidade na carne.

A viabilização do acompanhamento completo da produção à distribuição (rastreabilidade) é feita através da chamada brincagem dos animais. A brincagem consiste na identificação do animal com códigos, desde o seu nascimento (ou até no máximo 12 meses de idade) até a colocação da carne proveniente dele nas gôndolas e o posterior acompanhamento gerencial de evolução de vendas e informações sobre a cadeia de suprimento. Dentro deste sistema o Carrefour já possui cerca de $\mathbf{5 0 . 0 0 0}$ animais baseados no Mato Grosso.

A estratégia de marketing a ser adotada pela empresa para a colocação do produto nas lojas não foi discutida de forma satisfatória, mesmo porque o palestrante deixou clara a sua especialização na parte operacional do negócio. Contudo, arrisca-se um modelo de comercialização: produto extremamente diferenciado em termos de qualidade (aspecto visual, distribuição, embalagem, exposição) e que tenha um apelo forte no que se refere à segurança do alimento e rastreabilidade, podendo assim ser comercializado com um diferencial significativo de preços em relação à: 1) num primeiro estágio, outras carnes vendidas na loja sem o selo de qualidade e 2) num segundo estágio, carnes de outros supermercados concorrentes, quando toda a carne vendida pela empresa estiver sendo vendida dentro dos padrões da cadeia da qualidade. 


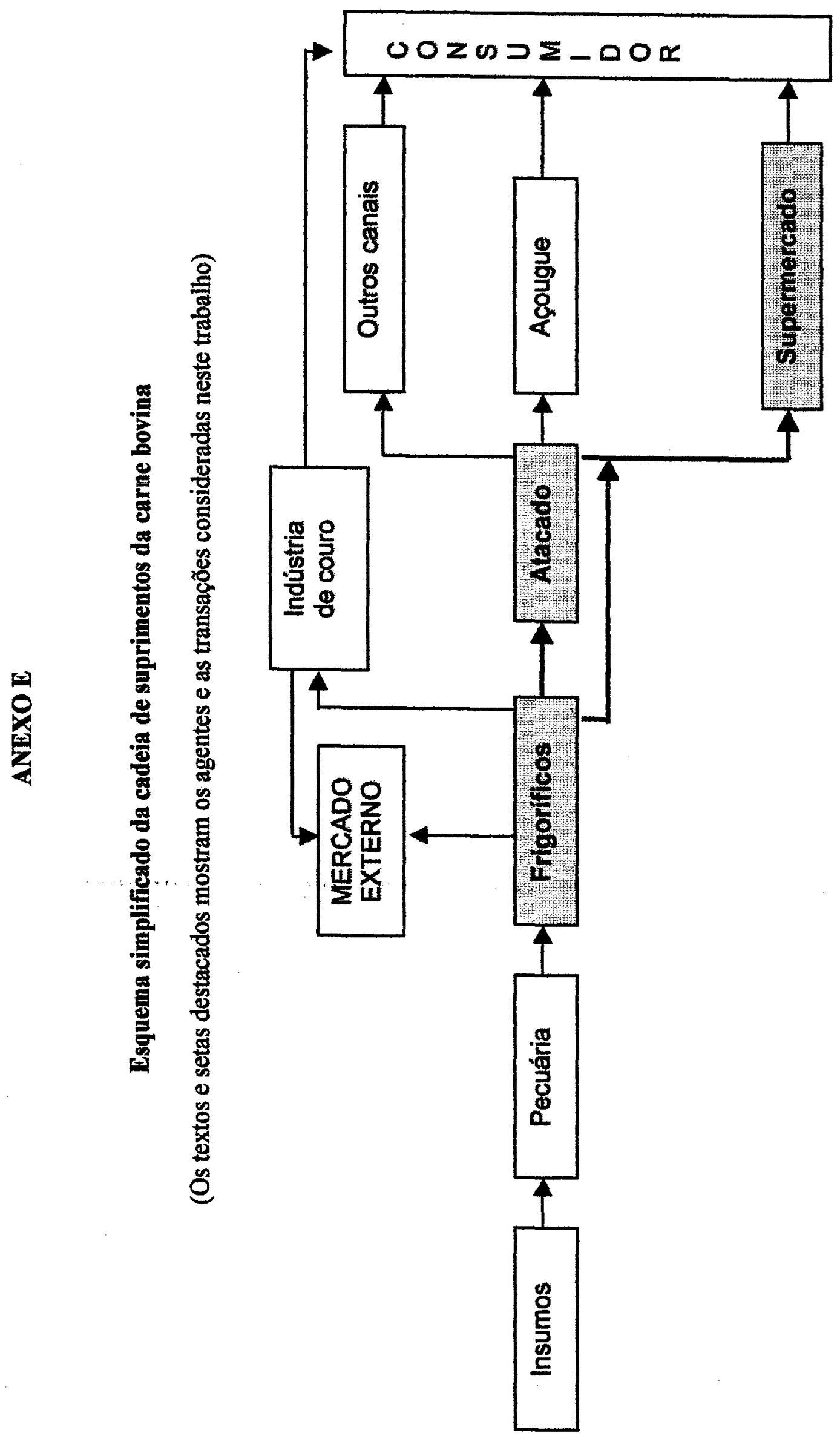




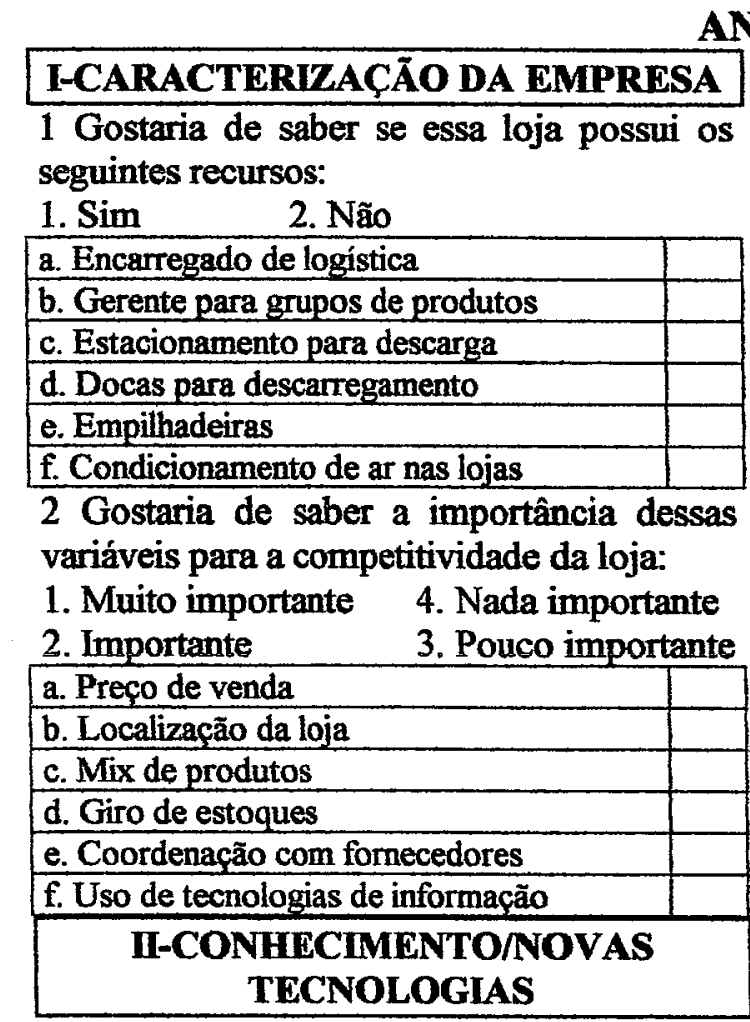

3 Gostaria de saber qual é o nível de conhecimento do Sr. a respeito de algumas novas tecnologias de varejo:
1. Conhece muito
3. Conhece pouco
2. Conhece/ouviu falar 4. Não conhece

\begin{tabular}{|l|l|}
\hline a. EDI-Troca Eletrônica de Dados & \\
\hline b. Códigos de barras & \\
\hline c. PDV-Terminal de Ponto de Venda & \\
\hline d. Custeio ABC & \\
\hline e. Reposição Contínua de mercadorias & \\
\hline f. Gerenciamento de categorias & \\
\hline g. Crossdocking & \\
\hline h. Paletização & \\
\hline
\end{tabular}

4 A ABRAS, em conjunto com outras entidades, lançou em 1997 o Programa ECR Brasil, que visa aumentar a eficiência da distribuição de produtos desde o fabricante até o varejista. Qual é o nível de conhecimento da sua empresa a respeito desse programa?

\begin{tabular}{|l|l|l|l|}
\hline 1. Conhece muito & 3. Conhece pouco & \\
\hline $\begin{array}{l}\text { 2. Conhece/ouviu } \\
\text { falar }\end{array}$ & 4. Não conhece & \\
\hline
\end{tabular}

\section{III-PADRONIZAÇÃO NA VENDA DE CARNE BOVINA}

5 No que se refere ao total de carne recebida pela loja por semana, qual o percentual aproximado de carne:
$1.0 \%$
2.Até $20 \%$
4.De $40 \%$ a $60 \%$
5.De $60 \%$ a $80 \%$
3.De $20 \%$ a $40 \%$
6.De $80 \%$ a $100 \%$

5 . desossada sem embalagem

6. desossada e embalada em peças

7. desossada e embalada em cortes prontos

8. desossada e embalada em cortes prontos c/ marca do fornecedor

9. desossada e embalada em cortes prontos, paletizada

10 No que se refere ao total de carne manipulada pelo açougue por semana, qual o percentual aproximado de venda de:
$1.0 \%$
4.De $40 \%$ a $60 \%$
2.Até $20 \%$
5.De $60 \%$ a $80 \%$
3.De $20 \%$ a $40 \%$
6.De $80 \%$ a $100 \%$

10. carne embalada em cortes prontos

11. carne embalada e com código de barras

12. carne embalada $\mathrm{c} / \mathrm{marca}$ do fornecedor

13. carne embalada c/ marca do supermercado

14. carne embalada com etiqueta de identificação completa (origem do animal, sexo, idade do abate, etc.)

\section{IV-HÁBITOS DE COMPRA DE CARNE BOVINA}

15 Quem é o responsável direto pela reposição de carne bovina ?
1. Administração central
2. Própria Loja
16 Normalmente, como ocorre a reposição de carne bovina no estoque da loja ?

\begin{tabular}{|l|l|}
\hline 1. Telefonema/frigorifico & \\
\hline 2. Telefonema/atacadista & \\
\hline 3. Visita do frigorífico & \\
\hline 4. Visita do atacadista & \\
\hline 5. Computador/frigorífico & \\
\hline 6. Computador/atacadista & \\
\hline 7. Requisicăa/Central de frios da empresa & \\
\hline 8. Outro: & \\
\hline
\end{tabular}

17 Com qual frequeencia a loja costuma tratar da reposição de estoques ?

\begin{tabular}{|l|l|l|l|}
\hline 1. Diariamente & 5. Just in time & \\
\hline 2. Semanalmente & 6. Indefinida & \\
\hline 3. Quinzenalmente & & 7. Nâ sabe & \\
\hline 4. Mensalmente & & & \\
\hline
\end{tabular}


18 Quais desses são os fatores decisivos para decidir o quanto comprar ?

\begin{tabular}{|l|l|}
\hline 1. Comportamento esperado da demanda & \\
\hline 2. Preço dos produtos disponiveis & \\
\hline 3. Comportamento das vendas passadas & \\
\hline 4. Usa algoritmo de controle de estoques & \\
\hline
\end{tabular}

19 Quais os fatores decisivos para decidir de qual frigorifico comprar?

\begin{tabular}{|l|l|}
\hline 1. Preços no momento da compra & \\
\hline 2. Qualidade da carne vendida & \\
\hline $\begin{array}{l}\text { 3. Cumprimento da entrega } \\
\text { programada }\end{array}$ & \\
\hline $\begin{array}{l}\text { 4. Venda de carne desossada e } \\
\text { embalada }\end{array}$ & \\
\hline
\end{tabular}

20 Normalmente, de quantos fornecedores a loja recebe a carne bovina:

\begin{tabular}{|c|c|}
\hline 1. Até 2 & 4. De 6 a 8 \\
\hline 2. De 2 a 4 & 5. De 8 a 10 \\
\hline 3. De 4 a 6 & 6. Mais de 10 \\
\hline
\end{tabular}

21 Quais ações poderiam ser tomadas no fornecimento para proporcionar a redução de custos na reposição de estoques?

\begin{tabular}{|c|}
\hline $\begin{array}{l}\text { a. Manter a escala de entregas } \\
\text { programada }\end{array}$ \\
\hline $\begin{array}{l}\text { b. Diminuir tempo entre pedido e } \\
\text { entrega }\end{array}$ \\
\hline c. Utilizar veículos mais adequados \\
\hline d. Melhorar condições de pagto./preços \\
\hline $\begin{array}{l}\text { e. Incentivar troca eletrônica de } \\
\text { informações }\end{array}$ \\
\hline $\begin{array}{l}22 \text { Vou citar uma série de atividades } \\
\text { relacionadas à comercialização de carne } \\
\text { bovina e gostaria de saber se esta firma } \\
\text { pratica ou não: } \\
0 . \text { Não pratica } \\
\text { 1.Pratica fracamente (Com } 1 \text { fornecedor) }\end{array}$ \\
\hline $\begin{array}{ll}\text { 2.Pratica } & \text { moderadamente(alguns } \\
\text { fornecedores) } & \end{array}$ \\
\hline
\end{tabular}
4. Pratica muito (Com todos os fornecedores)

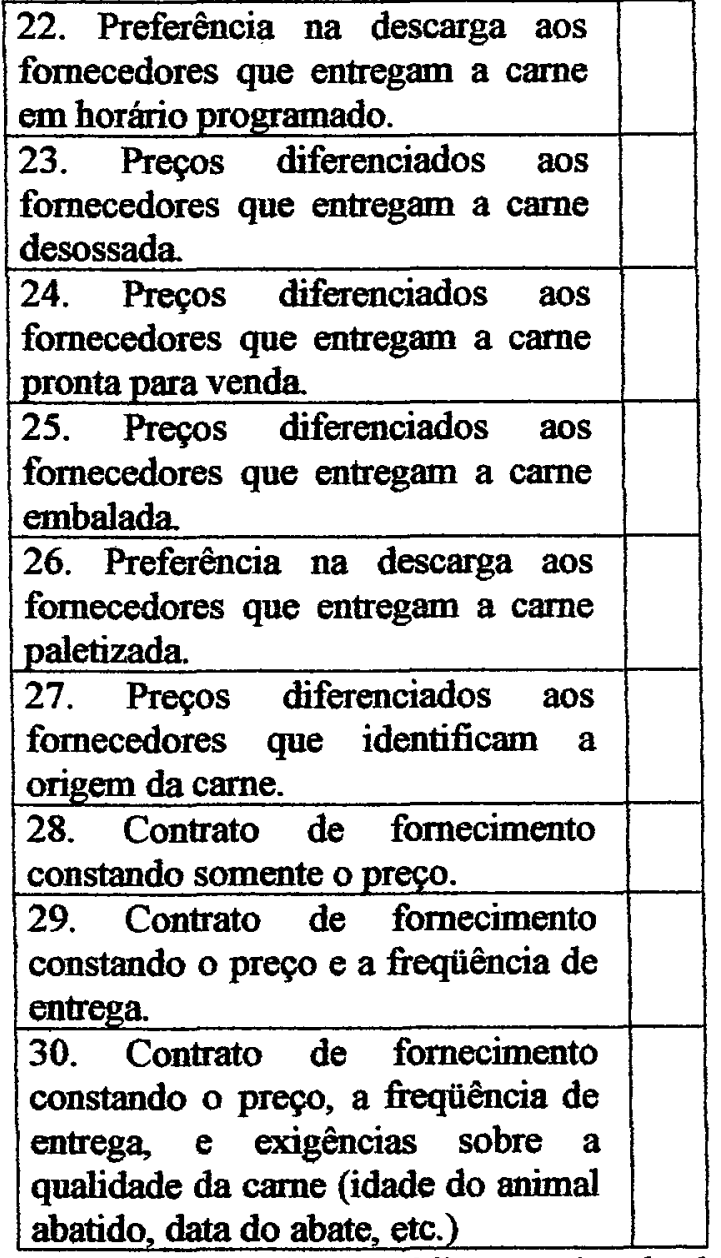

31 Qual é o volume médio aproximado de carne bovina comprada por semana para esta loja?

\begin{tabular}{|c|c|c|}
\hline $\begin{array}{l}\text { 1. Até } \\
2\end{array}$ & $3.6 \mathrm{a} 10$ & 5.14 a 18 \\
\hline $\begin{array}{lll}2 . & 2 & a \\
6 & & \end{array}$ & $\begin{array}{lll}4 . & 10 & a \\
14 & & \\
\end{array}$ & $\begin{array}{l}\text { 6. Mais de } \\
18\end{array}$ \\
\hline
\end{tabular}

32 Quais os dois principais fornecedores de carne bovina?

a.

b. 


\section{BIBLIOGRAFIA}

ABRAS. Revista Super Hiper - Ranking 1997. São Paulo. junho de 1998.

AKERLOF, G. A. The market for lemons: quality uncertainty and the market mechanism. Quarterly Journal of Economics, v. 84. n. 8. p.488-500. 1970.

ÂNGELO, C.F. de. Varejo: modernização e perspectivas. Atlas. São Paulo. PROVAR. 202p. 1994.

ARNTZEN, B.C. et al. Global Supply Chain Management at Digital Equipment Corporation. Interfaces 25:1. p.69. 1995.

ASSOCIAÇÃO ECR BRASIL. 21 questões sobre ECR. ABRAS. São Paulo. 1998.

BASTOS, R. R. Análise de dados categóricos. Apostila do curso de Pós-Graduação em métodos estatísticos computacionais. UFJF. Mimeo. 1996.

BAtalHA, M. O A gestão da produção em firmas agroindustriais. Produção. No.

Especial. ABEPRO. Belo Horizonte. novembro 1994.

BECKER, G. Investment in Human Capital: Effects on Earnings. Journal of Political Economy, v.70. n.10. p. 9-49. 1962.

BELOTO, P.B. Tipificação e Rastreabilidade de Carcaças. In: Anais do $3^{\circ}$ Congresso Brasileiro das Raças Zebuinas. Integração da Cadeia Produtiva Pecuária. 1998.

BNDES. Comércio varejista: supermercados. Informe setorial. www.bndes.gov.br. 1996.

BNDES. Cadeia da Carne Bovina: os desafios da Coordenação Vertical. Informe setorial. www.bndes.gov.br. 1998.

BLISKA, F.M.M.; GONÇALVES, J.R. Estudo da Cadeia Produtiva da Carne Bovina no Brasil. In Cadeias Produtivas e Sistemas Naturais - Prospecção Tecnológica. Castro, A M.G. et al. Embrapa. Brasília. 1998.

BOWERSOX, D.; CLOSS, D. Logistical management: the integrated supply chain process. McGraw Hill. New York. 730p. 1996.

COASE, R. H. The nature of the firm. Economica N.S. vol. 4. P. 386-405. 1937.

CYRILLO, D.C. O papel dos supermercados no varejo de alimentos. IPE. São Paulo. 198p. 1987. 
DE ZEN, S. et al. Cadeia Produtiva da carne bovina no Brasil. Revista Preços Agrícolas. ESALQ-DEAS/CEPEA. n. 154. p. 13. ago. 1999.

EVERITT, B.S. The analysis of contingency tables. 2 ed. Monographs on statistics and applied probability 45. Chapman \& Hall. 164 p. 1992.

FARINA, E. M. M. Q. Padronização em Sistemas Agroindustriais in: Cinco ensaios sobre gestão de qualidade no agribusiness. IX Seminário Internacional de Agribusiness do PENSA/FIA/FEA. 1999.

FAVERET FILHO, P; DE PAULA, S.R.L. Cadeia da carne bovina: o novo ambiente competitivo. BNDES Setorial. n. 6. set. 1997.

FEARNE, A. Editorial note. Supply chain management. v.1. n.1. pp. 3-4. 1996.

FEARNE, A. Building partnerships in the meat supply chain: the case of the UK beef industry. Mimeo. Food Industry Management Group. University of London. 45 p. jun. 1998.

FERNANDES JR., W.B.; NEVES, M.F. Estudo de caso: Companhia Real de Distribuição. VI Seminário Internacional de Agribusiness do PENSA/FIA/FEA. v.5. 1997.

GAZETA MERCANTIL. Balanço Anual. Vários números.

GAZETA MERCANTIL. Relatório: dossiê supermercados. 12 de março de 1999. 4p.

GEOFFRION, A.M.; POWERS, R.F. Twenty years of strategic distribution system design: an evolutionary perspective. Interfaces 25:5. p.105. 1995.

GRAHAM, C.F.; NAZEM, S.M. From electronic data interchange to efficient consumer response: new directions for the food industry. Journal of Food Products Marketing. v.3. n.2. p. 39. 1996

HARST, P.J.; SAUNDERS, C.S. Emerging Electronic Partnerships: antecedents and dimensions of EDI use from the supplier's perspective. Journal of Management Information Systems. v.14. n.4. p. 87. 1998.

HEIJBROEK, A.M.A.; VAN NOORT, W.M.H.; VAN POTTEN, A.J. The retail food market: structure, trends and strategies. Rabobank. Nederland. 67p. 1994.

HOBAN, T.J. Food industry innovation: efficient consumer response. Agribusiness-an international journal. v.14. n.3. p.235. John Wiley \& Sons. New York. 1998. 
HOBBS, J. E.; KERR, W. A. Cost of monitoring and vertical coordination in agribusiness: what can be learned from the British Act 1990. Agribusiness-an international Journal, v. 8. n. 6. p.575-584. 1992.

HOFFMANN, R. Estatística para Economistas. 2 ed. São Paulo. Pioneira. 426 p. 1991.

HOFFMANN, R.; KAGEYAMA, A.A Distribuição de renda no Brasil, entre famílias e entre pessoas, em 1970 e 1980. Estudos Econômicos. v.16. n. 1. p. 25-51. jan-abr. 1986.

JANK, M. S. A rastreabilidade nos agronegócios. in: Cinco ensaios sobre gestão de qualidade no agribusiness. IX Seminário Internacional de Agribusiness do PENSA/FIA/FEA. 1999.

JONES, T.C.; RILEY, D.W. Using inventory for competitive advantage through supply chain management. International Journal of Physical Distribution and Materials Management. v. 15. n. 5. pp. 16-26. 1985.

KALWANI, M.; NARAYANDAS, N. Long term manufacturer-supplier relationships: do they pay off for supplier firms. Journal of Marketing, v. 59. n. 1. p. 1-16. 1995.

KASPER, J.F.P. Produtividade e gerenciamento de operaçōes na empresa supermercadista. ABRAS. São Paulo. 175p. 1991.

KINDLEBERGER, C.P., Standards as Public, Collective and Private Goods. Kyklos. v. 36. fasc. 3. p. 377-396. 1983.

KLEIN, B.; CRAWFORD, R.A.; ALCHIAN, A.A Vertical integration, Appropriable rents, and the competitive contracting process. Journal of Law and Economics. v.21. n. 10. p. 297-326. 1978.

KOOPMANS, T. Three essays on the state of economic science. New York, McGraw Hill, 1957.

LANDEROS, R.; MONCZKA, R.M. Cooperative buyer/seller relationships and a firm's competitive posture. Journal of Purchasing and Materials Management. v. 25. n. 3. p. 9-18. 1989.

LEE, H. L.; PANDMANABHAN, V.; WHANG, S. Information distortion in a supply chain: the bullwhip effect. Management Science. v. 43. n. 4. pp. 546-558. 1997. 
LOMBARDI, M.C. Rastreabilidade: Exigências Sanitárias dos Novos Mercados. In: Anais do $3^{\circ}$ Congresso Brasileiro das Raças Zebuínas. Integração da Cadeia Produtiva Pecuária. 1998.

MACBETH, D. K.; FERGUSON, N. Partnership sourcing: na integrated supply chain management approach. Pitman Publishing. London. 1994.

MALONI, M.J; BENTON, W.C. Supply chain partnerships: opportunities for operations research. European Journal of Operational Research. v.101. n.3. North Holland. Amsterdam. 1997.

MATTHEWS, R.C.O The economics of institutions and the sources of economic growth. Economic Journal, v. 96. n. 12. p. 903-18. 1986.

MATHIAS, J.F.C.M. Modernização e Qualidade no Sistema Agroindustrial da Carne Bovina Brasileira. Dissertação de Mestrado. Instituto de Economia da UNICAMP. 1999.

MELO, P.R.S.; MOLLER JR, O. Panorama da automação comercial no Brasil. BNDES Setorial. n.5. p.129. 1997.

NAVAJAS, P. F. EDI: um estudo sobre sua adoção por uma empresa brasileira do ramo de varejo. Dissertação de Mestrado. FEA/USP. 114p. 1997.

PEETZ, V. da S. et. al. Cadeia produtiva da carne bovina no Estado de São Paulo. Secretaria da Agricultura e Abastecimento do Estado de São Paulo. 51 p. 1996

PENROSE, E. The theory of the growth of the firm. Oxford University. Oxford. 1959.

PINO, F. Estatística aplicada às ciências sociais. Apostila do curso de estatística do mestrado em Economia Aplicada. DEAS-ESALQ. Mimeo. 1998.

POSSAS, M.L. Estruturas de mercado em oligopólio. Hucitec. São Paulo. 2 ed. 1987.

REVISTA DE AUTOMAÇÃO COMERCIAL. O drama do recebimento. n. 43. p. 20. mai. 1997.

REVISTA DE AUTOMAÇÃO COMERCIAL. Donald Dufek - O papa da ECR. n. 44. p. 19. jun. 1997.

SANTOS, A.M.M.; COSTA, C.S. Características gerais do varejo no Brasil. BNDES Setorial. n.5. p.55. 1997.

SHARMA, S. Applied Multivariate Techniques. John Wiley \& Sons. Inc. New York. 
493 p. 1996.

SIFFERT FILHO, N.; FAVERET FILHO, P. O Sistema Agroindustrial de Carnes:

Competitividade e Estruturas de Governança. Revista do BNDES. v. 10. n. 4. 1998.

SOUCIE, W.G. Efficient consumer response meets the industrialization of agriculture.

Agribusiness - an international journal. v.13. n.3. p.349. John Wiley \& Sons. New York. 1997.

STEINDL, J. Maturidade e estagnação no capitalismo americano. Graal. Rio de Janeiro. 1983.

STEVENS, G.C. Integrating the supply chain. International Journal of Physical

Distribution and Materials Management. v.19. n. 8. p. 3-8. 1989.

SUPER HIPER. O açougue pode fazer a diferença. São Paulo. p. 32-38. abr. 1999.

SUPERMERCADO MODERNO. $\mathbf{O}$ açougue será muito mais produtivo. São Paulo.

p. 38-39. mar. 1992.

VAN DER VORST, J.G.A.J. et al. Supply chain management in food chains: improving performance by reducing uncertainty. International Transactions in Operational Research. v.5. n.6. p.487. 1998.

XAVIER, G. G. JT and Supply Chain Management: an information processing perspective. Produção. v. 8. n. 1. p. 45-62. ABEPRO. Belo Horizonte. 1996.

WEDEKIN, I.; NEVES, M.F. Sistema de distribuição de alimentos: o impacto das novas tecnologias. V Seminário Internacional de Agribusiness do PENSA/FIA/FEA. Estudo temático 001/95. 1995.

WILLIAMSON, O E. Markets and hierarchies: Analysis and Antitrust Implications. New York. Free Press. 1975.

WILLIAMSON, O E. The mechanisms of Governance. New York. Oxford University Press. 429 p. 1996.

ZYLBERSTAJN, D.; FARINA, E.M.M.Q. Agri-systems management: recent development d applicability of the concept. In: Anais do I Workshop "Agri-chain Management". Faculdade de Economia, Administração e Contabilidade da Universidade de São Paulo. Ribeirão Preto. 1997. 